INSTITUTO DE PESQUISAS ENERGÉTICA E NUCLEARES
\end{abstract}

Autarquia Associada à Universidade de São Paulo

\title{
ASPECTOS AMBIENTAIS DO PROCESSO DE \\ FABRICAÇÃO DE PLACAS DE REVESTIMENTOS \\ CERÂMICOS (VIA ÚMIDA), COM ÊNFASE NOS \\ EFLUENTES LÍQUIDOS
}

Kátia Regina Ferrari

Tese apresentada como parte dos requisitos para obtenção do Grau de Doutor em Ciências na Área de Tecnologia Nuclear - Materiais.

Orientador:

Dr. José Octavio Armani Paschoal

Co-Orientador:

Dr. Paulo Miranda de Figueiredo Filho

São Paulo 
Dedico este trabalho à Venina, à Déborah e à Flávia, como forma de apresentar o meu agradecimento pelo apoio e estímulos, incondicionais, a mim oferecidos e que constituem $o$ alicerce da edificação do meu futuro. 
"Aqueles de nós aos quais tem sido dado o privilégio de desenvolver recursos, construindo e operando fábricas e usinas, distribuindo bens e serviços para o mercado e instruindo clientes sobre o que devem ou não devem comprar, aqueles de nós deveriam, primeiramente, aceitar a responsabilidade de explicar os impactos ambientais de seus empreendimentos."

Rodney Chase; Managing Director

British Petroleum, September 1994 


\section{ipen}

\section{AGRADECIMENTOS}

Ao iniciarmos uma tese nunca sabemos ao certo os caminhos a serem percorridos. Temos mais incertezas do que convicções. Deparamos com obstáculos que acreditamos ser impossíveis de transpor. No entanto, estas barreiras são, de uma forma ou de outra, vencidas. Começamos a assimilar os conhecimentos. Aos poucos as certezas se consolidam, as dúvidas já não são tantas e o trabalho vai seguindo seu rumo. Porém, em todas estas fases, se não existissem pessoas dispostas a dar seu apoio, transmitir suas experiências e repartir o seu tempo com pareceres, discussões e "dicas" preciosas, seria impossível desenvolvermos e concluirmos o trabalho. Por este motivo deixo expresso meu sincero agradecimento às Pessoas, aos Institutos e às Empresas que, direta ou indiretamente, contribuíram com o desenvolvimento e a conclusão deste trabalho. Em especial agradeço:

- Ao Conselho Nacional de Desenvolvimento Científico e Tecnológico - CNPq pelo apoio financeiro por meio do processo número 141955/96-1.

- Ao Instituto de Pesquisas Energéticas e Nucleares - IPEN / CNEN - SP.

- À MSc Clarice Maria Rispoli Botta Paschoal do Centro de Recursos Hídricos e Ecologia Aplicada - CRHEA / USP / São Carlos, Dr. Pedro Antonio Zagatto da CETESB/SP, MSc. Sandra Regina Mattiolo Marthese do CTM, Dra. Maria Beatriz Camino Bohrer, Dra. Mônica Beatriz Mathor, MSc. Silvia Gonçalves Egler, Dra. Sueli Ivone Borrely do IPEN, pela disponibilização dos laboratórios, execução e orientação na realização dos testes de toxicidade e pelas discussões técnicas.

- Ao Professor Dr. José Renato Coury do Departamento de Engenharia Química da UFSCar, pelas discussões técnicas relativas as emissões gasosas.

- Ao MSc. Flávio M. S. Carvalho do Instituto de Geociências da USP pela disponibilização do laboratório, execução e orientação na realização das análises por difração de raio $X$.

- À Dra. Ivone Mulako Sato, Marcos Antonio Scapin, MSc. Vera Lúcia Ribeiro 


\section{ipen}

Salvador, Wilson Santo Scapin Junior, do IPEN, pela disponibilização do laboratório, execução e orientação na realização das análises por fluorescência de raio $X$.

- Aos técnicos João Batista de Andrade, Marco Antonio Andrade, Paulo César da Silva, Renato Giordano, Ricardo Cavaleiro e Valdir de Oliveira, pela colaboração em diversas etapas do trabalho e confecção de instrumentos utilizados na coleta de amostras.

- À MSc. Ana Lúcia E. Godoy, Glauson Aparecido F. Machado e Celso Vieira de Moraes do IPEN, pela disponibilização do laboratório, preparação das amostras e realização das análises de microscopia eletrônica de varredura.

- Ao Dr. José Oscar Willian Veja Bustillos, Dr. Nelson Batista de Lima, MSc. Sérgio Carvalho Moura do IPEN, por me incentivarem e convencerem a começar este trabalho e pela disponibilização da infra-estrutura laboratorial na fase inicial.

- Ao Dr. Waldemar Avritscher e MSc. Reynaldo Arbue Pini do Laboratório do Projeto Gálio - LPG da EPUSP / Minas, pela disponibilização do laboratório e execução das análises por Espectrometria de Absorção Atômica

- Ao Engenheiro Luiz Alberto Machado, Fátima Moreira, João Paulo Acevedo Perez, pelas valiosas discussões técnicas, disponibilização de importantes informações e materiais imprescindíveis para realização deste trabalho.

- Ao Dr. Reginaldo Muccillo e Yone V. França do IPEN, pela disponibilização do laboratório e execução das análises termodiferenciais e termogravimétricas.

- Ao Eduardo Pecci Junior, MSc. Elita Urano de C. Frajndlich, Dra. Fátima Maria Sequeira de Carvalho, MSc. Iara Maria C. de Carvalho, MSc. Luiz Antonio Abdalla de Moura, MSc. Mari Estela de Vasconcellos, Maria Aparecida Alves, MSc. Maria Nogueira Marques, Dra. Marlene Flues SottoMayor, Dra. Nilse Ortiz, Dra. Ruth Camilo Luquese, Sueli da Silva Casquel, pelas colaborações diversas e discussões técnicas.

- Aos Orientadores Dr. José Octavio Armani Paschoal e Dr. Paulo Miranda de Figueiredo Filho do IPEN, por acreditarem e dedicarem seu tempo dando todo apoio para a realização do nosso trabalho. 


\title{
ASPECTOS AMBIENTAIS DO PROCESSO DE FABRICAÇÃO DE PLACAS DE REVESTIMENTOS CERÂMICOS (VIA ÚMIDA), COM ÊNFASE NOS EFLUENTES LÍQUIDOS
}

\author{
Kátia Regina Ferrari
}

\section{RESUMO}

No presente estudo buscou-se desenvolver uma metodologia simplificada para avaliar o impacto ambiental do processo de fabricação de placas de revestimentos cerâmicos - via úmida. Para dar subsídios ao desenvolvimento do modelo de avaliação ambiental e para obter um maior conhecimento do processo produtivo, foram elaboradas planilhas que correlacionavam as etapas do sistema produtivo com os tipos e volumes de resíduos nele gerados. Relacionaram-se a estas planilhas, as normas técnicas da Associação Brasileira de Normas Técnicas (ABNT), as quais determinam as metodologias de amostragem, caracterizações, monitoramento, tratamento dos resíduos sólidos e efluentes líquidos e gasosos; as Legislações Federal e Estadual pertinentes, as quais dispõem sobre o controle da poluição ambiental. O modelo de avaliação do impacto ambiental aqui proposto, foi desenvolvido partindo-se da Matriz de Interação de Leopold e da Matriz de Risco, na qual identificou-se os efeitos poluidores (críticos, significativos, reduzidos e 
marginais) das etapas deste processo produtivo. A validação destes resultados foi obtida pela realização de ensaios analíticos nas matérias-primas utilizadas e nos resíduos gerados no processo produtivo. Os resultados das análises químicas reforçam que a toxicidade positiva nos efluentes líquidos está relacionada com a composição química dos insumos utilizados na decoração. Os resíduos sólidos que mais comprometem o meio ambiente são aqueles provenientes dos setores de preparação e aplicação de tintas e vidrados. Também realizou-se um estudo de caracterização das matérias-primas naturais e no produto, utilizando as técnicas de fluorescência de raio $X$, análise termodiferencial e termogravimétrica, microscopia eletrônica de varredura e difração de raio $X$, buscando compreender as interações dos componentes da massa do corpo cerâmico, durante a etapa de queima, e sua influência na qualidade do produto final. Essas informações são úteis, tanto do ponto de vista da caracterização cristaloquímica das matérias-primas que compõem o corpo cerâmico, identificando sua evolução quando submetidos a processos de queima, quanto do ponto de vista ambiental, servindo de base para estudos futuros que promovam o estabelecimento de especificações de controle de massa, e melhor aproveitamento dos recursos minerais, evitando eventuais desperdícios durante o processo. Com a consolidação de todos os dados foi possível indicar, em cada etapa do processo produtivo, as não conformidades existentes com relação às especificações legais, bem como sugestões para sua adequação ambiental. 


\title{
ENVIRONMENTAL ASPECTS OF THE PROCESS OF PRODUCTION OF CERAMIC TILES (WET PROCESS), WITH EMPHASIS IN LIQUID EFFLUENTS
}

\author{
Kátia Regina Ferrari
}

\section{ABSTRACT}

Present study developed a simplified methodology to evaluate the environmental impacts of the wet process of production of ceramic tiles. In order to subsidize the development of the model of environmental evaluation and to achieve a better understanding of the productive process, there were elaborated matrixes in which was correlated the stages of the productive system with the respective types and volumes of residues generated. To these matrixes there were related the technical norms of the Brazilian Association of Norms and Techniques (ABNT), which determines the sampling methodologies, characterizations, monitoring and treatment of the solid residues and liquid and gaseous effluents; and the pertinent Federal and State Legislations which dispose on the control of the environmental pollution. The evaluation of the environmental impact model here proposed was developed from the Interaction Matrix of Leopold and from the Risk Matrix proposed by Moura, in which identified the pollutant effects (critical, significant, reduced, marginal) of the 
stages of this productive process. The validation of these results was obtained through the accomplishment of analytic assays in the used raw materials and in the residues generated in the productive process. The results of the chemical analyses reinforce that the positive toxicity in the liquid effluent is related with the chemical composition of the synthetic raw material used in the decoration. It was concluded that the solid residues that more damage cause to the environment are those coming from the enamel and dying preparation and application sections. Concomitantly, it was performed a study of characterization of the natural raw materials and of the product, using different techniques as fluorescence $X$ ray, differential thermal analysis with thermogravimetry, scanning electron microscopy and $X$ ray diffraction, in order to understand the interactions of the components of the mass of the ceramic body, during the stage of burning and its influence in the quality of the final product. Also, under the environmental point of view, the set of information may be used as base for future works to define technical specifications of mass control, subsidizing orientations for a better use of the mineral resources avoiding eventual wastes during the process. With the consolidation of all data it was possible to indicate, in each stage of the productive process, the existent non-conformities, as well as suggestions for its environmental adaptation. 


\section{SUMÁRIO}

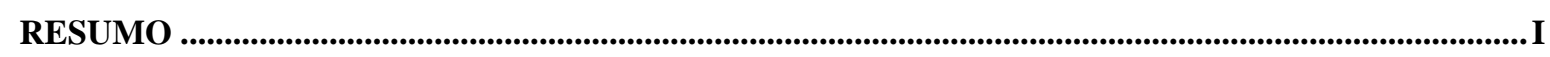

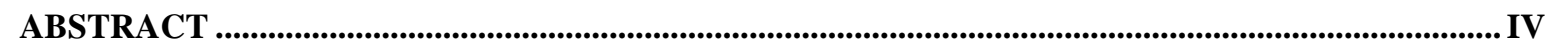

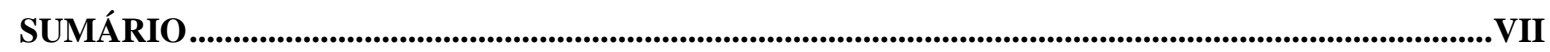

ÍNDICE DE TABELAS.......................................................................................................... VII

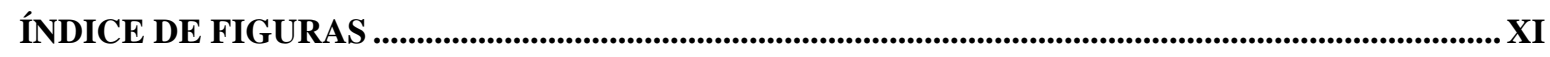

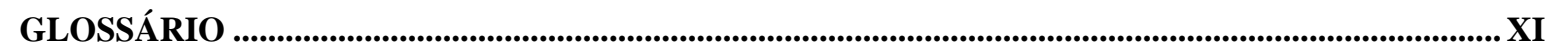

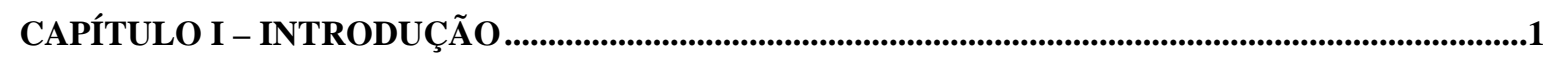

CAPÍTULO II - A INDÚSTRIA DE PLACAS DE REVESTIMENTOS CERÂMICOS...........................24

CAPÍTULO III - METODOLOGIA .......................................................................................................................41

CAPÍTULO IV - RESULTADOS E DISCUSSÃO .......................................................................66

CAPÍTULO V - ADEQUAÇÃO AMBIENTAL ............................................................................130

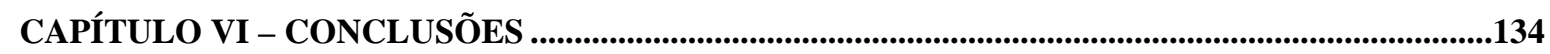

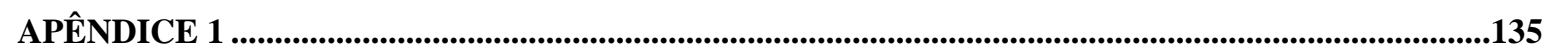

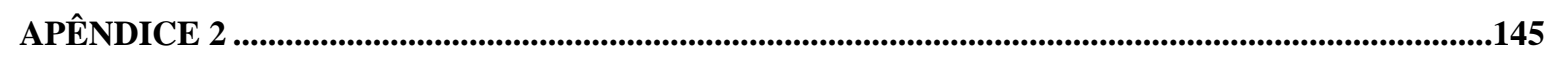

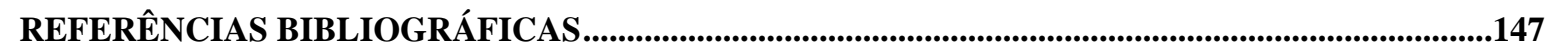

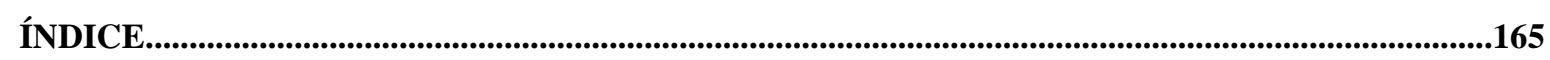




\section{ÍNDICE DE TABELAS}

Tabela 1: Exemplo de planilha de detalhamento dos aspectos ambientais e processos tecnológicos - Normas - ABNT das atividades da etapa de preparação da massa do corpo cerâmico - Monoqueima

Tabela 2: Relação de algumas das normas da ABNT - Associação Brasileira de Normas Técnicas relativas às metodologias de coleta e preservação de amostras, ensaios e classificação aplicáveis à poluição do ar, solo e líquidos (ABNT,1995).

Tabela 3: Exemplo de planilha de detalhamento dos aspectos ambientais e processos tecnológicos - Diplomas Legais Federal das atividades da etapa de preparação da massa do corpo cerâmico.

Tabela 4: Legislação Federal - resoluções CONAMA sobre controle de poluição ambiental.

Tabela 5: Exemplo de planilha de detalhamento dos aspectos ambientais e processos tecnológicos - Diplomas Legais Estadual das atividades da etapa de preparação da massa do corpo cerâmico.

Tabela 6: Legislação Estadual - Decretos sobre controle de poluição ambiental do Estado de São Paulo.

Tabela 7: Categorias de Gravidade

Tabela 8: Níveis de freqüência ou probabilidade de ocorrência de impactos ambientais negativos.

Tabela 9: Condições de leitura amostra/padrão para as análises químicas por espectrometria de absorção atômica.

Tabela 10: Resultado teste de toxicidade aguda com Daphnia similis - data da coleta 15/12/97.

Tabela 11: Resultado dos testes de toxicidade aguda com Daphnia similis - data da coleta 13/04/98.

Tabela 12: Matriz de Avaliação de Impactos Ambientais para Indústria de Revestimento Cerâmico / Processo via úmida - Setor de Monoqueima 
Tabela 13: Matriz de Avaliação de Impactos Ambientais para Indústria de Revestimento Cerâmico / Processo via úmida - Setor de Biqueima.

Tabela 14: Análise semi-quantitativa, realizada pela técnica analítica fluorescência de raio x (WDXRF) - método dos parâmetros fundamentais, de alguns óxidos presentes na argila cinza padrão (ACP) e na argila azul teste (AAT). Valores em porcentagem de óxidos

Tabela 15: Análise química semi-quantitativa das massas cerâmicas usando a argila cinza padrão (ACP) e a argila azul teste (AAT), pela técnica fluorescência de raio $X$, método da pastilha fundida. Valores em porcentagem de óxidos.

Tabela 16: Análise semi-quantitativa, realizada pela técnica analítica fluorescência de raio $\mathrm{x}$ (WDXRF) - método dos parâmetros fundamentais, de alguns insumos de decoração utilizados na monoqueima e na biqueima. Resultados em porcentagem de óxidos. Coleta 15/01/98.

Tabela 17: Análise semi-quantitativa, realizada pela técnica analítica fluorescência de raio x (WDXRF) - método dos parâmetros fundamentais, dos resíduos sólidos decantados dos respectivos efluentes líquidos. Resultados em porcentagem de óxidos. Coleta 15/01/98.

Tabela 18: Análise semi-quantitativa, realizada pela técnica analítica fluorescência de raio $\times$ (WDXRF) - método dos parâmetros fundamentais, em alguns insumos de decoração da monoqueima e da biqueima e do resíduo sólido do tanque de decantação da etapa de preparação de tintas e vidrados da monoqueima. Resultados em porcentagem de óxidos. Coleta 24/08/99.

Tabela 19: Resultado dos testes de toxicidade aguda com Daphnia similis - data da coleta 24/09/99.

Tabela 20: Resultado dos testes de toxicidade aguda com Daphnia similis - data da coleta $26 / 10 / 99$

Tabela 21: Resultado dos testes de toxicidade aguda com Daphnia similis - data da coleta 23/11/99.

Tabela 22: Comparação das análises químicas realizadas por espectrometria de absorção atômica no efluente líquido do Ponto B-1 (efluente da seção de moagem). Amostras coletadas em diferentes dias. Valores expressos em $\mathrm{mg} \cdot \mathrm{L}^{-1}$ 
Tabela 23: Comparação das análises químicas realizadas por espectrometria de absorção atômica no efluente líquido do ponto B-2 (preparação de tintas e vidrados). Amostras coletadas em diferentes dias. Valores expressos em mg. $\mathrm{L}^{-1}$

Tabela 24: Comparação das análises químicas realizadas por espectrometria de absorção atômica no efluente líquido do ponto B-3 (efluente líquido da linha de decoração do setor de monoqueima). Amostras coletadas em diferentes dias. Valores expressos em mg. $\mathrm{L}^{-1}$

Tabela 25: Comparação das análises químicas realizadas por espectrometria de absorção atômica no efluente líquido do ponto B-4 (efluente líquido do setor de biqueima ponto de liberação para a rede pública de esgoto). Amostras coletadas em diferentes dias. Valores expressos em mg. $\mathrm{L}^{-1}$

Tabela 26: Comparação das análises químicas realizadas por espectrometria de absorção atômica no efluente líquido do ponto B-5 (ponto de liberação para a rede pública de esgoto). Amostras coletadas em diferentes dias. Valores expressos em mg. $\mathrm{L}^{-1}$

Tabela 27: Comparação das análises químicas realizadas por espectrometria de absorção atômica no efluente líquido do ponto B-6 (água de abastecimento) e os limites máximos permissíveis para água potável Portaria $\mathrm{n}^{\circ}$ 36/GM - Secretaria de Estado da Saúde. Amostras coletadas em diferentes dias. Valores expressos em $\mathrm{mg} \cdot \mathrm{L}^{-1}$

Tabela 28: Comparação das análises químicas realizadas por espectrometria de absorção atômica no efluente líquido do ponto B-7 (efluente líquido do laboratório do controle de qualidade). Amostras coletadas em diferentes dias. Valores expressos em mg. $\mathrm{L}^{-1}$

Tabela 29: Comparação das análises químicas realizadas por espectrometria de absorção atômica no efluente líquido do ponto B-8 (efluente líquido da linha de decoração do setor de biqueima). Amostras coletadas em diferentes dias. Valores expressos em $\mathrm{mg} \cdot \mathrm{L}^{-1}$

Tabela 30: Comparação dos resultados obtidos nos pontos críticos identificados pela metodologia das matrizes e pelos dados analíticos 
Tabela 31: Análise química por espectrometria de absorção atômica nos efluentes líquidos da indústria cerâmica. Amostras com ácido nítrico e sem ácido nítrico. Data de coleta 01/02/2000. Valores expressos em $\mathrm{mg} \cdot \mathrm{L}^{-1}$.

Tabela 32: Capacidade de Troca lônica de alguns grupos de argilominerais. Em pH 7.

Tabela 33: Níveis de tolerância à exposição dos elementos químicos mais utilizados na indústria de placas de revestimentos cerâmicos.

Tabela 34: Níveis de tolerância à exposição dos elementos químicos mais utilizados na indústria de placas de revestimentos cerâmicos (continuação tabela 33)

Tabela 35: Níveis de tolerância à exposição dos elementos químicos mais utilizados na indústria de placas de revestimentos cerâmicos (continuação das tabelas $33 \mathrm{e}$ 34)

Tabela 36: Planilha de detalhamento dos aspectos ambientais e processos tecnológicos - Normas - ABNT das atividades da etapa de preparação da massa do corpo cerâmico, monoqueima (continuação - TAB 4).

Tabela 37: Planilha de detalhamento dos aspectos ambientais e processos tecnológicos - Normas - ABNT das atividades da etapa de preparação da massa do corpo cerâmico, monoqueima (continuação).

Tabela 38: Planilha de detalhamento dos aspectos ambientais e processos tecnológicos - Normas - ABNT das atividades da etapa de preparação da massa de decoração do revestimento cerâmico, monoqueima.

Tabela 39: Planilha de detalhamento dos aspectos ambientais e processos tecnológicos - Normas - ABNT das atividades da etapa de decoração do revestimento cerâmico, monoqueima.

Tabela 40: Planilha de detalhamento dos aspectos ambientais e processos tecnológicos - Normas - ABNT das atividades da etapa de queima e seleção do revestimento cerâmico, monoqueima.

Tabela 41: Planilha de detalhamento dos aspectos ambientais e processos tecnológicos - Normas - ABNT das atividades da etapa de preparação da massa do revestimento cerâmico / Biscoito, biqueima. 
Tabela 42: Planilha de detalhamento dos aspectos ambientais e processos tecnológicos - Normas - ABNT das atividades da etapa de preparação da massa de decoração do biscoito, biqueima.

Tabela 43: Planilha de detalhamento dos aspectos ambientais e processos tecnológicos - Normas - ABNT das atividades da etapa de decoração do biscoito, biqueima.

Tabela 44: Planilha de detalhamento dos aspectos ambientais e processos tecnológicos - Normas - ABNT das atividades da etapa de embalagem, seleção e estoque das peças cerâmicas, biqueima.

Tabela 45 Registro de dados da água de diluição para os testes de toxicidade aguda com Daphnia similis. 


\section{ÍNDICE DE FIGURAS}

Figura 1 Processo de urbanização ocorrido no Brasil entre 1940 até 1995.

Figura 2: Relações de causa-efeito de agressões ambientais na extração de matérias-primas minerais para indústria de revestimento cerâmico.

Figura 3: Caracterizações físicas (cor de queima; dilatação / retração; absorção de água) de corpos de prova formados a partir das matérias-primas amostradas em: (A) - detalhamento de uma jazida, amostras coletadas em diversas profundidades; (B) - amostras diversas, coletadas em datas e jazidas diferentes.

Figura 4: Efeitos do lançamento de dióxido de enxofre $\left(\mathrm{SO}_{2}\right)$ por uma indústria.

Figura 5: Representação esquemática do processo de fabricação de revestimentos cerâmicos por via úmida e por via seca.

Figura 6: Fluxograma do processo produtivo - matérias-primas e insumos utilizados e os resíduos gerados.

Figura 7: Matriz de Risco

Figura 8: Exemplo de teste de toxicidade agudo: (A) teste preliminar: identificação do intervalo de concentrações para realização do teste definitivo; (B) teste definitivo: identificação da concentração do efluente que causa a imobilidade de $\mathbf{5 0} \%$ dos organismos (Concentração Efetiva - CE50\%).

Figura 9: Localização dos pontos de amostragem do processo de fabricação de revestimentos cerâmicos. Identificação dos pontos de amostragem dos efluentes líquidos

Figura 10: Avaliação das etapas do processo de fabricação de placas de revestimentos cerâmicos pelo método da matriz de avaliação de impactos ambientais

Figura 11: Curva termodiferencial - argila cinza padrão (ACP). .................77

Figura 12: Curva termogravimétrica - argila cinza padrão (ACP).............. 77

Figura 13: Curva termodiferencial - argila azul teste (AAT) ....................... 78 
Figura 14: Curva termogravimétrica - Argila Azul Teste (AAT).

Figura 15: Interface $\triangle$ - corpo cerâmico(I) -engobe(II) -esmalte (III) de um piso - setas indicam os poros na camada de esmalte com diâmetros variando entre 5 a $50 \mu \mathrm{m}$.

Figura 16: Interface $\nabla$ - corpo cerâmico (I) - esmalte de um azulejo (III) - setas indicam os poros na camada do esmalte com diâmetros variando entre 5 a $50 \mu \mathrm{m}$

Figura 17: Corpo cerâmico (I) - material vítreo, ação dos cátions modificadores: seta branca - poro; seta preta - grão de calcita; estrela - grãos de quartzo.

Figura 18: Difratogramas de raio $X$ demonstrando 0 comportamento térmico da massa de revestimento cerâmico.

Figura 19: Representação gráfica dos resultados das análises químicas por espectrometria de absorção atômica realizadas no efluente líquido do setor de moagem das matérias-primas naturais ( $B-1)$

Figura 20: Representação gráfica dos resultados das análises químicas por espectrometria de absorção atômica realizadas no efluente líquido do setor de preparação de tintas e vidrados (B-2) .

Figura 21: Representação gráfica dos resultados das análises químicas por espectrometria de absorção atômica realizadas no efluente líquido da linha de decoração da monoquiema (B-3)

Figura 22: Representação gráfica dos resultados das análises químicas por espectrometria de absorção atômica realizadas no efluente líquido do setor de biqueima (B-4)

Figura 23: Representação gráfica dos resultados das análises químicas por espectrometria de absorção atômica realizadas no efluente líquido da caixa de coleta dos efluentes líquidos da linha de decoração da monoqueima e do laboratório de controle de qualidade (B-5)

Figura 24: Representação gráfica dos resultados das análises químicas por espectrometria de absorção atômica realizadas na água de abastecimento (B-6). 
Figura 25: Representação gráfica dos resultados das análises químicas por espectrometria de absorção atômica realizadas no efluente líquido do laboratório de controle de qualidade (B-7).

Figura 26: Representação gráfica dos resultados das análises químicas por espectrometria de absorção atômica realizadas no efluente líquido da linha de decoração da biqueima (B-8)

Figura 27: Difratograma realizado nos sólidos presentes no efluente líquido do ponto B-4.

Figura 28: Difratograma realizado nos sólidos presentes no efluente líquido do ponto B-5.

Figura 29: Difratograma realizado nos sólidos presentes no efluente líquido do ponto B-1.

Figura 30: Comparação das caracterizações de alguns elementos presentes na poeira total em suspensão na atmosfera do Município de Santa Gertrudes e do Parque Dom Pedro / São Paulo 


\section{GLOSSÁRIO}

Aspecto Ambiental: Segundo a ISO 14000 - Treinamento de Auditores Ambientais da P-E Batalas (1996) aspecto ambiental é uma atividade cujo resultado gera impacto ambiental e podem ser: diretos - aqueles que a organização tem controle; indiretos - aqueles os quais a organização pode ter influência para alcançar controle limitado; existentes - aspectos que atualmente já se manifestam (inclusive no passado); e aspectos ambientais a serem gerados por novos desenvolvimentos aqueles que podem vir a existir com a inclusão de novos produtos, serviços e atividades.

Atomizador:

Equipamento utilizado para secagem e granulação (atomização) da barbotina. A barbotina é bombeada para dentro do atomizador onde, por um bico dosador, esta massa líquida é borrifada e as gotículas entram em contato com o ciclone de ar quente (aproximadamente $150^{\circ} \mathrm{C}$ ). As gotículas são secadas formando grânulos de forma esférica com umidade entre 6,3 a 6,8\%. Estes grânulos são armazenados em silos para posterior prensagem. A massa cerâmica atomizada apresenta melhor escoamento e preenchimento homogêneo das matrizes de prensagem.

Barbotina:

Massa líquida obtida após a moagem a úmido das matérias-primas naturais.

Biqueima:

Processo de queima realizado em duas etapas. A primeira ocorre a sinterização das placas de revestimentos cerâmicos, formando 0 biscoito. A segunda etapa de queima ocorre após a decoração do biscoito para vitrficação dos esmaltes e estabilização das cores.

Chamote:

Placas de revestimentos cerâmicos quebradas no decorrer do processo, antes da etapa de queima (monoqueima ou biqueima)

Diagnóstico: Conjunto de medidas e controles realizado para determinar ou verificar as características técnicas de um sistema, afim de garantir a manutenção ou a melhoria das condições ambientais. 
Engobe:

Esmalte:

Fritas:

Listelos:

Massa cerâmica:

Massa de decoração:

Monoporosa:

Monoqueima:

Peças a verde:

Prognóstico:
Composto, basicamente, de misturas de massa do corpo cerâmico com material vítreo, aplicado numa camada intermediária entre o corpo cerâmico e a decoração, cuja função é proporcionar a aderência do esmalte ao corpo cerâmico e minimizar os defeitos ocasionados pelos diferentes comportamentos térmicos do corpo cerâmico e do esmalte. $O$ engobe também tem função opacificante, proporcionando o recobrimento das imperfeições do corpo cerâmico impedindo que elas interfiram na camada de decoração.

Cobertura vítrea altamente opacas devido à presença de silicato de zircônio, óxido de titânio,e óxido de estanho, entre outros

Material vítreo fundido é um tipo especial de esmalte denominado frita transparente, são aplicadas em finas camadas sobre as decorações proporcionando brilho à peça. As fritas são compostas, basicamente, de carbonato de chumbo, carbonato de cálcio, fundentes, caulim e quartzo. Podem ser utilizadas também como veículo de constituintes corantes, permitindo a obtenção de uma variedade maior de texturas e superfícies coloridas.

Placas de revestimentos cerâmicos para incremento decorativo de paredes. Após assentadas formam faixas decorativas.

Mistura de diversas matérias-primas naturais (Caulinita, Talco, Filito, Calcita, Taguá, e outras)

Pasta obtida após a moagem a úmido de diferentes tipos de matérias-primas sintéticas (fritas, esmaltes, corantes, feldspatos, carbonatos, entre outros)

Tipo de placa de revestimento cerâmico com alto volume de poros, portanto de baixa resistência mecânica e de menor peso utilizada para revestimento de paredes.

Processo de queima de placas de revestimento cerâmico onde ocorre numa única etapa a sinterização do corpo cerâmico, a vitrificação dos esmaltes e estabilização das cores.

Placas de revestimento cerâmico (decoradas ou não) antes de passar pelo processo de queima (monoqueima ou biqueima)

Previsão, suposição sobre o que deve acontecer em relação aos impactos ambientais 
Sinterização: $\quad$ Processo de queima que promove a densificação do material (aumento da massa sem alterar o volume), por meio de transformações de fases cristalinas, formação de material vítreo e recobrimento de poros.

Vascas: Recipiente utilizado para transporte de massa de decoração para abastecimento das linhas de decoração 


\section{CAPÍTULO I}

\section{INTRODUÇÃO}

\section{I.1. DESENVOLVIMENTO ECONÔMICO EM HARMONIA COM MEIO AMBIENTE, UMA RESPONSABILIDADE GLOBAL}

Segundo dados da Fundação Instituto Brasileiro de Geografia e Estatística - IBGE (GUSMÃO et al., 1990), no Brasil, as primeiras preocupações com o meio ambiente surgiram, sobretudo, a partir da década de 30, quando teve início, no país, o processo de industrialização e de intervenção do Estado, na economia nacional. As primeiras medidas sobre a questão ambiental tinham caráter esporádico e atingiam o saneamento de áreas urbanas e a conservação e preservação do patrimônio natural, com a criação de parques nacionais, ao mesmo tempo em que, periodicamente, voltavam-se para o atendimento dos problemas causados pela ocorrência de secas e de enchentes que assolavam o país.

Segundo GUSMÃO et al. (op. cit.) com a expansão da industrialização intensificavam-se os problemas ligados à poluição do ar e das águas nas áreas urbanas, os quais foram agravados pelo rápido processo de urbanização, 
ilustrado pela figura 1, ocorrido no País, responsável pela deterioração das condições de saneamento.

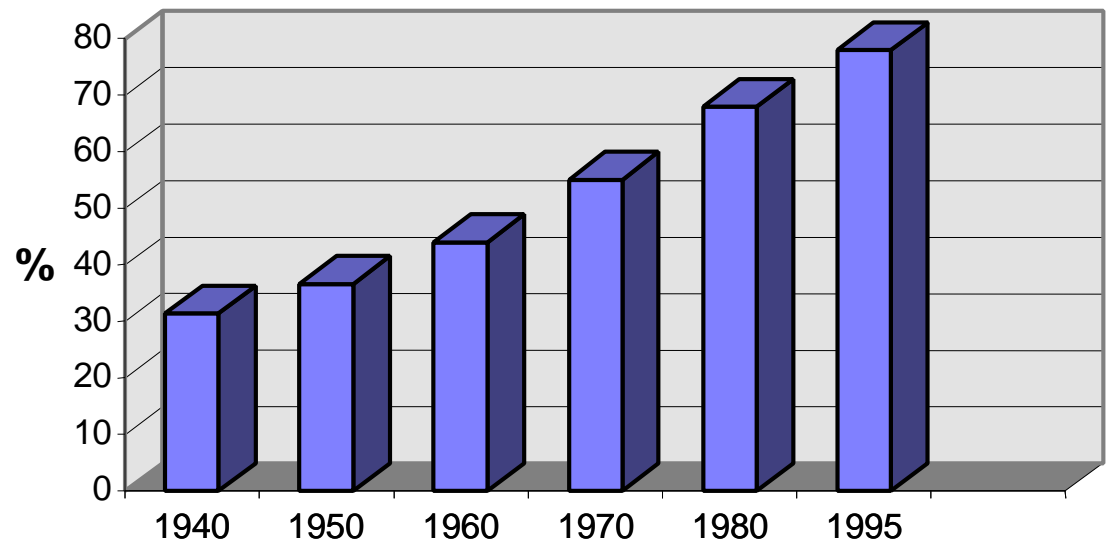

Figura 1: Processo de urbanização ocorrido no Brasil entre 1940 até 1995. Fonte: PASCHOAL, 1997

As áreas de maior concentração da atividade industrial, conseqüentemente, são as que apresentam maiores problemas de degradação ambiental cuja gravidade irá depender do volume de sua produção, da composição de sua estrutura industrial e das medidas de controle adotadas.

Neste sentido, cabe ressaltar que a Política Nacional do Meio Ambiente, fundamentada nos termos da Lei Federal $n . \stackrel{0}{6.938}$, de 31 de Agosto de 1981, artigo $2^{\circ}$ (BRASIL, 1981), "tem por objetivo a preservação, melhoria e recuperação da qualidade ambiental propícia à vida, visando assegurar, no País, condições ao desenvolvimento sócio-econômico, aos interesses da segurança nacional e à proteção da dignidade humana". 
Enquanto que a Legislação Estadual, em seu artigo $2^{\circ}$ da Lei $n^{\circ} 997$, de 31 de maio de 1976 do Estado de São Paulo (SÃO PAULO, 1976f), considera poluição do meio ambiente "a presença, o lançamento ou a liberação, nas águas, no ar ou no solo, de toda e qualquer forma de matéria ou energia, com intensidade, em quantidade de concentração ou com características em desacordo com as que forem estabelecidas em decorrência desta Lei, ou que tornem ou possam tornar as águas, ar ou solo:

I. Impróprios, nocivos ou ofensivos à saúde;

II. inconvenientes ao bem estar público;

III. danosos aos materiais, à fauna e à flora;

IV. prejudiciais à segurança, ao uso e gozo da propriedade e às atividades normais da comunidade".

A elaboração de normas e políticas de proteção ao meio ambiente são especificamente orientadas por três princípios básicos:

- Princípio da Prevenção: estabelecido pelo artigo 2ํo da Lei Federal 6.938/81 (BRASIL, 1981).

De acordo com suas disposições a "política nacional do meio ambiente tem por objetivo a preservação, melhoria e recuperação da qualidade ambiental propícia à vida". De acordo com tal princípio, as medidas que visem à prevenção de danos ao meio ambiente devem ter prioridade sobre aquelas que visem sua reparação. 
- Princípio do Poluidor-Pagador: estabelecido pela Lei Federal 6.938/81 (BRASIL, 1981), em seu artigo 4ํㅜ, vii.

Pode ser definido como obrigação do poluidor de recuperar e indenizar danos por ele causados ao meio ambiente.

Tal princípio deve ser analisado em conjunto com o artigo 14, iv, parágrafo $1^{\circ}$, da mencionada lei, segundo o qual:

"sem obstar a aplicação das penalidades previstas neste artigo, é o poluidor obrigado, independentemente da existência de culpa, a indenizar ou reparar os danos causados ao meio ambiente e a terceiros, afetados por suas atividades. O Ministério Público da União e dos Estados terá legitimidade para propor ação de responsabilidade civil e criminal por danos causados ao meio ambiente".

Em vista de tal princípio, e da noção de responsabilidade objetiva e solidária, os sucessores, e qualquer um que direta ou indiretamente contribua para a prática de um ato danoso ao meio ambiente, pode ser por tal ato responsabilizado.

- Princípio da Cooperação

De acordo com este princípio, genericamente previsto no artigo 225 da Constituição Federal, o Estado e a sociedade devem trabalhar lado a lado para solucionar problemas ambientais (TOZZINI et al., 1999). 
PLANTENBERG e AB'SABER (1994) chamaram a atenção que a compatibilidade ambiental e social é o problema primário dessa e das futuras gerações. Os efeitos das atividades humanas que atuam em detrimento ao meio ambiente vêm, de forma abrangente, preocupando a sociedade moderna. Fica claro que as parcerias são fundamentais para tornar autêntico o desenvolvimento sustentável de um programa de gerenciamento ambiental que apresente um processo sistemático de revisão e controle. Sob este aspecto de responsabilidade global, os países industrializados adquiriram uma espécie de "dívida ecológica", que tem como desafio propiciar a melhoria e recuperação da qualidade ambiental essencial à sadia qualidade de vida.

O panorama do comércio internacional também está sofrendo forte influência da pressão social causada pela conscientização da preservação do meio ambiente. Segundo REPETTO (1996) a abertura do comércio internacional pretende atingir a otimização dos recursos disponíveis, admitindo que determinados países se especializem em produtos e serviços nos quais encontrem alguma vantagem competitiva sobre os demais, permitindo que os consumidores adquiram bens e serviços de países que os produzam com mais eficiência. $\mathrm{O}$ autor explica que a proteção ambiental tende a atingir o mesmo nível de eficiência, assegurando que o incremento total dos custos da produção e do consumo estarão refletidos nas políticas das indústrias. O que já pode ser observado é que o resultado desta busca pela conquista de novos mercados, empreendida pelos diversos setores produtivos, está ditando um desenvolvimento com maior harmonia com o meio ambiente. 
CORSON (1996) destacou que desenvolvimento econômico e meio ambiente interagem. $\mathrm{O}$ crescimento de um em detrimento do outro resulta no colapso de ambos. É comum observar pessoas responsáveis pela administração dos recursos naturais e proteção ao meio ambiente organizadas separadamente daqueles responsáveis pela direção da economia.

Visando a mudança deste quadro, economistas do mundo inteiro discutem regras de mercado para o livre comércio, buscando coadunar concorrência, qualidade e eficiência dos produtos, estabilidade econômica dos países em desenvolvimento, com aspectos de proteção ambiental.

De acordo com BARBIERI (1999) os entendimentos a respeito dos impactos do comércio internacional sobre o meio ambiente encontram-se envoltos em controvérsias e polêmicas acirradas. O autor destacou ainda, que a expansão deste comércio é visto por uns como condição para resolver os problemas ambientais, constituindo uma oportunidade única para universalizar a adoção de padrões ambientais rigorosos, enquanto para outros ela intensifica a degradação ambiental. O resultado final seria o afrouxamento desses padrões ou a permanência de padrões diferenciados, de um lado os países limpos e de outro, os paraísos dos poluidores.

Independente destas posições extremadas, e que ainda irão se estender por mais alguns anos para atingirem um denominador comum, o mercado internacional já apresenta uma postura clara, não aceitando produtos e/ou serviços de empresas que, para reduzir os preços, faltam com as regras de 
controle de poluição, segurança no trabalho, entre outros. Esta postura intensifica a importância de uma abordagem ambiental para a indústria do setor de revestimento cerâmico em função àquelas diferenciações de matériasprimas, processos e produtos.

Segundo ALMEIDA (1998) o debate, inicialmente concentrado nos países desenvolvidos, incorporou crescentemente a problemática ambiental dos países em desenvolvimento, culminando com o reconhecimento mútuo da necessidade de um esforço conjunto, de ações integradas entre os povos para construção desse novo modelo de desenvolvimento.

A lucratividade e a rentabilidade das empresas são fortemente influenciadas pela sua capacidade em antecipar e reagir frentes às mudanças sociais e políticas que ocorrem em seu ambiente de negócios (DONAIRE, 1995). Atualmente, as empresas estão sendo compelidas a assumir essas novas responsabilidades, diferentes daquelas referentes a "o que produzir", "como produzir" e "para quem produzir", atingindo um espectro muito mais amplo, envolvendo preocupações de maior amplitude, tais como controle da poluição, segurança e qualidades de produtos. Essa visão é resultado de uma mudança de enfoque no sentido de prevenção à poluição.

Obviamente, a importância do desenvolvimento de estudos ambientais, seja de prognóstico ou controle para mitigação ou neutralização dos efeitos impactantes, é clara (ALVES, 1993; HEMENWAY e GILDERSLEEVE, 1995). Contudo, há um enfoque que deve ser destacado: as medidas corretivas que 
asseguram a redução do impacto ambiental são específicas a cada setor, devendo-se considerar as particularidades e os aspectos pontuais, tanto para a região de instalação como para o processo produtivo da indústria. Para tanto, um amplo estudo deve ser efetuado para determinar as causas e proporcionar um relacionamento mais harmônico entre empresa e meio ambiente (MORIN, 1993; LIPIETZ, 1994; PLANTENBERG e AB'SABER, 1994).

Segundo a pesquisa realizada pela Gazeta Mercantil (GESTÃO, 1996), em relação aos países desenvolvidos, a gestão ambiental responde à existência de barreiras à aceitação de produtos ambientalmente inadequados, e à atitude de militância dos consumidores dispostos a pagar mais pelos ecoprodutos. Desta forma, a definição de qualidade é ampliada com a incorporação da variável ambiental, sendo o novo passo no ajuste competitivo das empresas face às imposições advindas da abertura de mercado.

WATHEN (1996) demonstrou que a rápida industrialização do último século aumentando, exponencialmente, as emissões tóxicas, geração de resíduos, extinção de espécies, alto consumo dos recursos naturais, entre outros, nos obriga buscar soluções imediatas ao conflito entre crescimento econômico e a proteção ambiental. Segundo SCHWARTZ e PRATT (1990) o volume de resíduos perigosos gerados por empreendimentos de pequeno porte correspondem de $20 \%$ a $65 \%$ do volume total de resíduos perigosos gerados em alguns estados e cidades dos Estados Unidos. É evidente o reconhecimento da importância dos acordos e medidas comerciais para 
ampliar a proteção ambiental, mas estas ações só serão efetivas se forem apoiadas no comprometimento de todos.

No Brasil observa-se que o processo de concentração da atividade industrial nos grandes centros urbanos não foi acompanhado de uma política que procurasse harmonizar os objetivos de crescimento econômico e o equilíbrio dos ecossistemas existentes (GUSMÃO et al., 1990). O interesse estava no crescimento econômico do País, na geração de empregos e não na proteção ao meio ambiente, originando um quadro de degradação ambiental, que em alguns casos é de difícil reversão. O panorama atual reflete esta falta de harmonia entre o desenvolvimento e o meio ambiente. No entanto, seja por aspectos econômicos (assegurar a competitividade) ou por pressão legal, muitos setores industriais estão buscando sua adequação ambiental.

ALMEIDA (1998) evidenciou, como um dos pontos importantes de seu estudo, que as teses mais pessimistas sobre a possibilidade de conciliar desenvolvimento econômico com proteção ao meio ambiente foram sendo superadas por aquelas que defendem a conciliação possível entre crescimento econômico, justiça social e prudência ecológica, sintetizadas por um único conceito: o desenvolvimento sustentável. Este final de milênio está marcado pela busca da harmonização das regras ambientais e de negócios e com a participação cada vez maior da sociedade, exigindo dos empresários atitudes inovadoras, inteligentes e eficazes, fatores essenciais para a permanência e abertura de novos mercados. 


\section{I.2. O SETOR DE REVESTIMENTO CERÂMICO E O MEIO AMBIENTE}

Apesar da posição invejável no cenário industrial brasileiro e mundial, a indústria brasileira de revestimento cerâmico ainda apresenta algumas deficiências, inclusive com relação às questões ambientais. A execução do projeto PADCT/CNPq, coordenado pelo Centro Cerâmico do Brasil - CCB, intitulado "Plataforma para a Indústria Brasileira de Revestimento Cerâmico“ (PASCHOAL, 1999), possibilitou a avaliação da Cadeia Produtiva da Indústria Cerâmica, dando ênfase às questões relacionadas ao desenvolvimento da massa e produto, "design" e ao sistema produtivo. Além dos problemas gerais, foram identificados também alguns problemas específicos, entre os quais aqueles relativos aos aspectos ambientais da cadeia produtiva traçando uma inter-relação destas dificuldades com as do processo de fabricação de placas de revestimento cerâmico.

As questões ambientais da cadeia produtiva, demonstradas pelo projeto Plataforma, demonstraram que os problemas diagnosticados na extração de matérias-primas naturais e nos colorifícios contribuem significativamente com os aspectos ambientais das indústrias que fabricam placas de revestimentos cerâmicos.

Da extração mal planejada às extrações balizadas em estudos da potencialidade da jazida, com caracterizações das matérias-primas, existe uma 
grande lacuna. A deficiência de critérios únicos, que promovam o fornecimento de matérias-primas com características suficientes para tornar desprezíveis as variações da massa que constitui o corpo cerâmico e que garantam a constância de qualidade na produção de placas de revestimentos cerâmicos, prejudicam o melhor aproveitamento das matérias-primas e a minimização de impactos ambientais.

A pesquisa geológica com dados geológicos insuficientes é mais regra do que exceção (FIGUEIREDO FILHO et al., 1999a). A figura 2 esquematiza as relações de causa e efeito que levam a agressões desnecessárias ao meio ambiente devido ao conhecimento insuficiente das jazidas. 


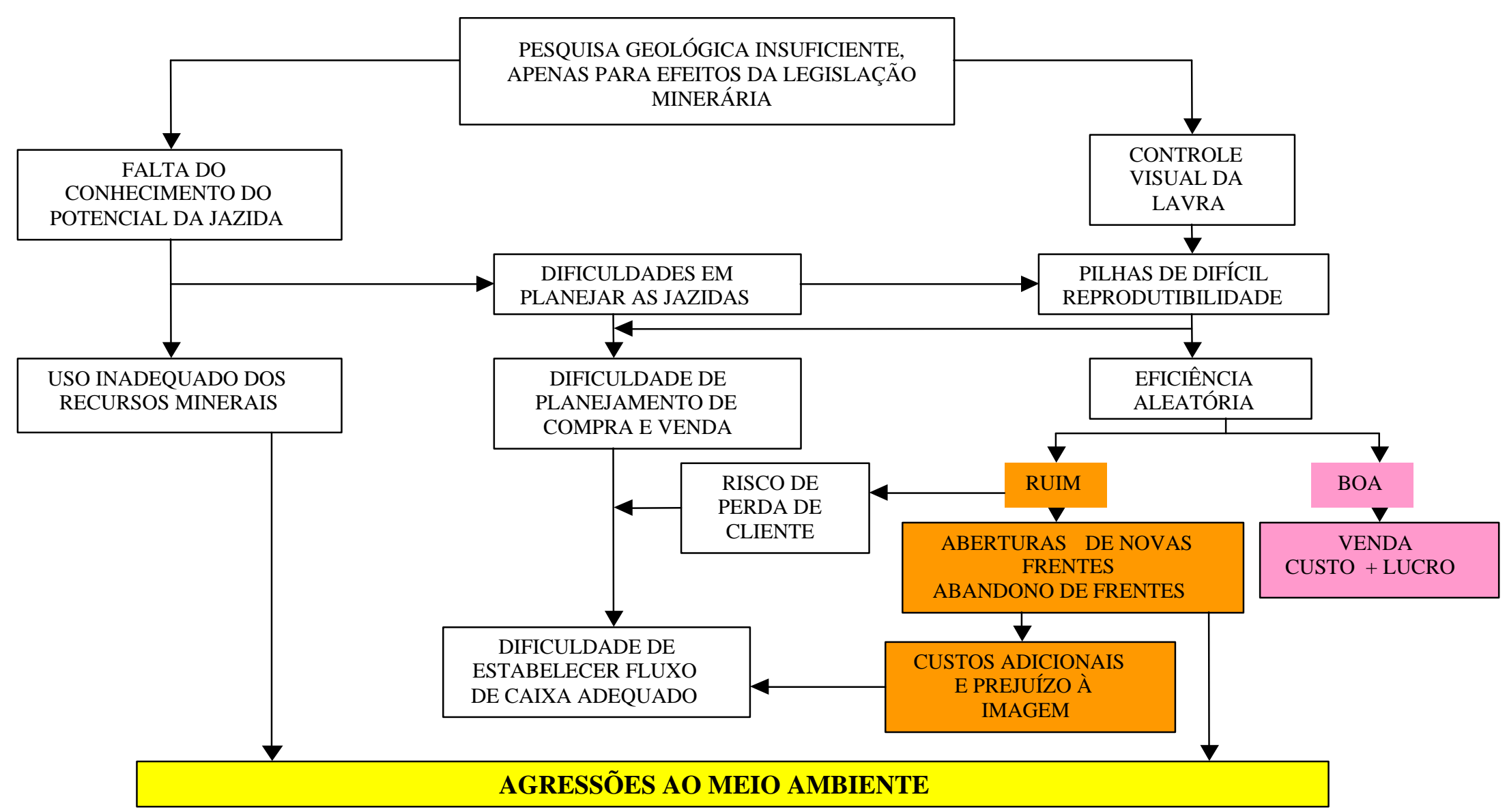

Figura 2: Relações de causa-efeito de agressões ambientais na extração de matérias-primas minerais para indústria de revestimento cerâmico.

Fonte: FIGUEIREDO FILHO et al., 1999a 
Interpretando a figura 2, verifica-se que a falta de conhecimento do papel das matérias-primas minerais nas propriedades do produto final, faz com que a classificação dos componentes da massa seja restrita a critérios empíricos. As minas são abertas a partir de dados insuficientes para o planejamento da lavra. Isto pode levar a indústria a mudar de fornecedores de matérias-primas naturais devido à falta de homogeneidade deste material, que altera a qualidade dos produtos fabricados. Esta variação nas especificações das matérias-primas naturais pode gerar desperdícios no processo, pois o novo lote deve ser analisado e testado; a formulação de massa deve ser adaptada e, geralmente, ocorrem adaptações na linha de produção, como alterações na quantidade de água necessária para a moagem, no tempo de moagem, no tempo e/ou na temperatura de queima, entre outros.

Observadas pelos aspectos ambientais, verifica-se que algumas jazidas possuem plano de recuperação de área degradada, com reflorestamento de mata nativa; sistemas de drenagens com tratamento de floculação dos efluentes líquidos, devolvendo, ao corpo receptor, água sem argila em suspensão. No entanto, este correto procedimento não se aplica na totalidade das atividades de extração de matérias-primas naturais para fabricação de placas de revestimentos cerâmicos.

A etapa de extração das matérias-primas naturais apresenta diversos problemas: mão-de-obra desqualificada e de alta rotatividade, extração sem planejamento e predatória, pesquisa geológica incipiente, entre outras. As 
jazidas mais estruturadas operam de forma mais organizada, enquanto que as de menor porte operam mais precariamente, com preços mais baixos e comprometimento dos custos de investimento. As dificuldades enfrentadas neste primeiro elo da cadeia produtiva atingem diretamente as etapas produtivas que ocorrem na indústria cerâmica (FIGUEIREDO FILHO et al., 2000). A solução para um sistema produtivo eficiente está na interação destes segmentos.

Muitas ações já estão sendo realizadas neste sentido, a figura 3 apresenta corpos de prova formados a partir das matérias-primas amostradas em diversas profundidades de uma jazida. As amostras foram caracterizadas segundo cor de queima; dilatação / retração e absorção de água. Estes dados ainda são insuficientes para garantir a eficiência destas matérias-primas durante o processo de fabricação, mas servem de referência ao setor para estabelecimento de procedimentos que resultem em melhorias, tanto sob aspectos ambientais como de mercado, aumentando a eficiência e competitividade do setor.

Segundo GRECO (1998) em virtude de um ineficaz controle do processo, desde a matéria-prima até o produto acabado, verifica-se uma elevada perda de produção (de até $15 \%$ ), devido a quebras, presença de trincas, irregularidades de cor, queimas indevidas ou bolhas nas superfícies das peças. Além disso, defeitos relacionados à dimensão das peças, 
empenamento, expansão por umidade, entre outros, acarretam problemas adicionais, com menor valorização dos produtos.

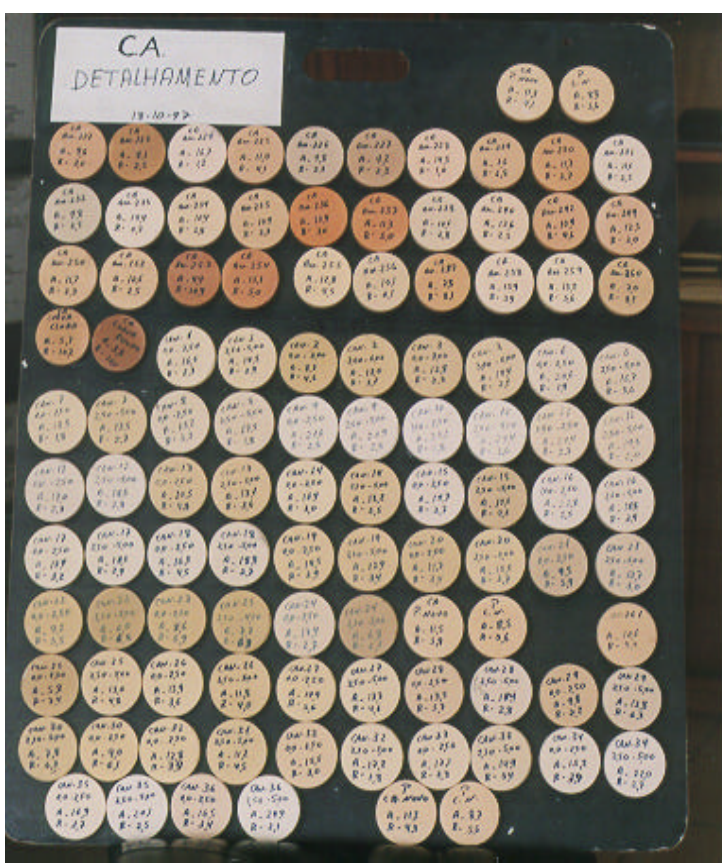

(A)

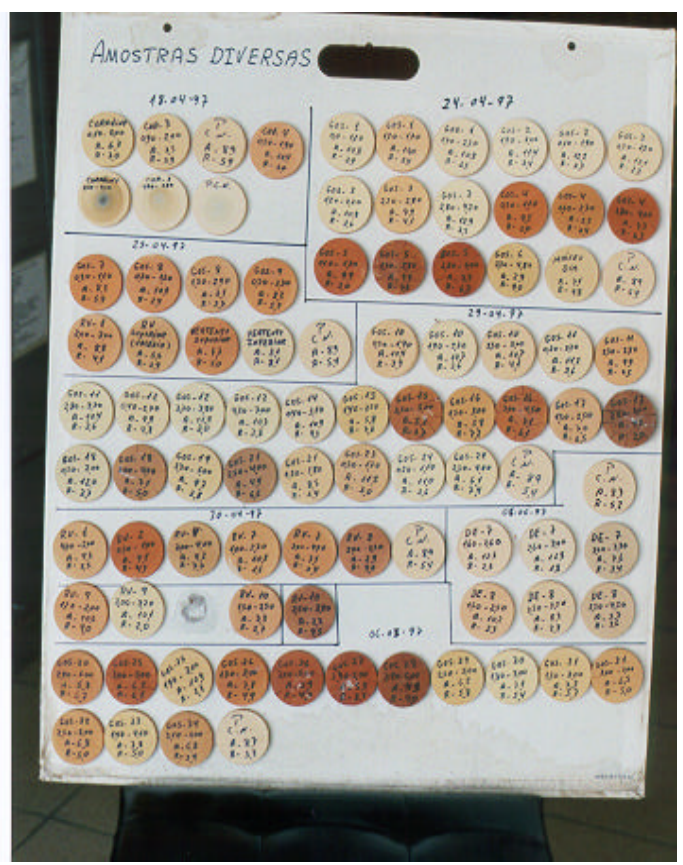

(B)

Figura 3: Caracterizações físicas (cor de queima; dilatação / retração; absorção de água) de corpos de prova formados a partir das matérias-primas amostradas em: (A) - detalhamento de uma jazida, amostras coletadas em diversas profundidades; (B) - amostras diversas, coletadas em datas e jazidas diferentes.

FONTE: Informação pessoal

Nos colorifícios, FIGUEIREDO FILHO et al. (1999b) constataram o elevado consumo de água durante a fabricação de fritas e o uso de metais tóxicos na composição dos insumos para decoração. Este último contribui negativamente nas condições ambientais das indústrias de fabricação de placas de revestimentos cerâmicos, pois acarretam a geração de resíduos 
tóxicos nas etapas de preparação e aplicação dos insumos de decoração nas placas cerâmicas.

Uma das conclusões obtidas pelo levantamento do perfil da indústria de cerâmica para revestimento, realizado pelo Banco Nacional de Desenvolvimento Econômico e Social - BNDES (GORINI e CORREA, 1999) foi que grande parte das empresas de cerâmica está investindo na melhoria de seu processo produtivo, seja na substituição de equipamentos, na ampliação da capacidade produtiva ou no desenvolvimento de novos produtos. Nesse sentido, o BNDES apoiou investimentos da ordem de 200 milhões de dólares na década de 90. No entanto, investimento semelhante para aquisição de tecnologias limpas e melhoria das condições ambientais ainda não ocorre de forma representativa neste setor.

Contrariamente ao que ocorre no Brasil, como conseqüência da evolução tecnológica, da pressão social e da concorrência, as indústrias de placas de revestimentos cerâmicos européias, principalmente as italianas e espanholas, investem em centros de pesquisa e desenvolvimento, visando melhorar o desempenho produtivo de suas instalações. Na questão ambiental diversos estudos são desenvolvidos objetivando a descontaminação de efluentes gasosos, água residual e resíduos sólidos gerados por estas indústrias, visando sempre manter as características de qualidade do produto ou incluindo melhorias. Estes estudos também visam um alto rendimento na 
descontaminação com um consumo mínimo de insumos e energia (BUSANI et al., 1995; BLASCO et al., 1997).

Todavia, no Brasil, já existem esforços pontuais no sentido da busca da melhoria ambiental do setor de revestimento cerâmico. Tanto na indústria cerâmica como na extração das matérias-primas minerais, os estudos relacionados à melhoria ambiental também visam a qualidade do produto e o aumento da competitividade deste setor. Destes estudos pode-se evidenciar o de RIPOLI FILHO (1997), o qual visou a utilização do chamote em tijolos e telhas, conferindo-lhes melhorias de qualidade, sendo uma alternativa econômica e eficiente para a diminuição de problemas de poluição. 0 revestimento cerâmico também pode ser utilizado como solução de resíduos de outros processos produtivos, podendo ser inertizados na massa do corpo cerâmico ou como substituto de matérias-primas naturais. OLIVEIRA (1999) verificou que a introdução de lama de cal, proveniente da fabricação de celulose, pode ser utilizada em massas para fabricação de peças do tipo monoporosa substituindo totalmente a calcita comercial e, além de ser economicamente viável, contribui para a redução do impacto ambiental.

O conhecimento técnico-científico de toda a cadeia produtiva de placas de revestimento cerâmico, estudado sob o ponto de vista ambiental, permitirá reduzir a quantidade de resíduos a um nível abaixo do atualmente praticado, além de permitir a reutilização da água, melhor aproveitamento de energia e matérias-primas, diminuindo, sobremodo, os volumes de resíduos e praticando 
custos competitivos. No entanto, para se alcançar estes resultados, cada elo que compõe esta cadeia produtiva deverá ser estudado separadamente, considerando suas características específicas em relação aos impactos ambientais gerados e só então implantar ações para controle e prevenção à poluição, diminuindo os desperdícios e aumentando os lucros.

\section{I.3. AVALIAÇÃO DOS IMPACTOS AMBIENTAIS NEGATIVOS}

Nos últimos anos, técnicas e métodos específicos para a análise de riscos industriais e ambientais passaram a ser amplamente empregadas, pois são importantes instrumentos de gerenciamento e planejamento, promovendo o conhecimento da extensão do problema, possibilitando o desenvolvimento de programas específicos que o contemplem de forma objetiva e eficaz (AMORIM, apud MAKARON, 1997). Segundo MOURA (1998) a análise de riscos e estudos de confiabilidade de instalações industriais são excelentes instrumentos para a determinação de impactos ambientais, e que os órgãos ambientais aprovam suas realizações, pois estes instrumentos demonstram, em termos probabilísticos, os riscos de acidentes ambientais.

Sob este aspecto, para se obter o conhecimento das características ambientais de um empreendimento, MOURA (1998) propõe que os impactos ambientais devem ser identificados, classificados e priorizados, levando-se em consideração as condições normais de operação, as condições anormais e as condições de riscos ambientais. 
TOMMASI (1994) apresentou diversos modelos que buscam este objetivo, tais como: listagem de controle, para identificação de impactos relevantes; matriz de ações e conseqüências, que permite identificar os impactos ambientais resultantes do empreendimento; rede de interação, que organiza uma seqüência de efeitos provocados pelos empreendimentos, entre outros. Um exemplo de rede de interação é apresentado na figura 4.

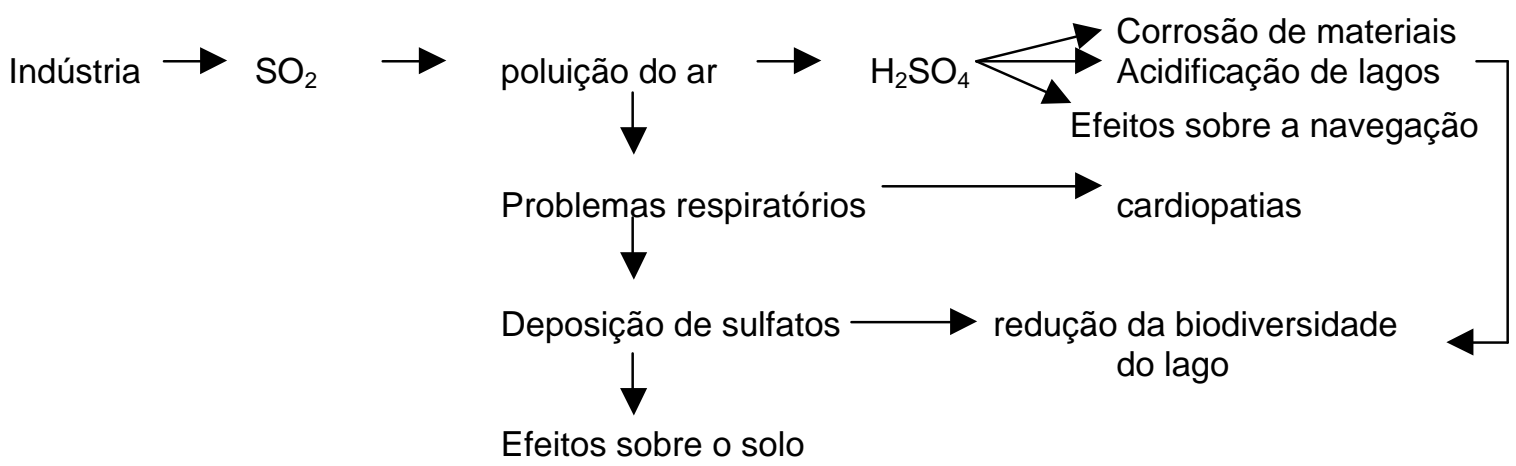

Figura 4: Efeitos do lançamento de dióxido de enxofre $\left(\mathrm{SO}_{2}\right)$ por uma indústria. Fonte: TOMMASI, (1994)

Outro modelo de avaliação de impactos ambientais é a matriz de interação desenvolvida por Leopold et al. (apud TOMMASI, 1994). Esta matriz correlaciona as atividades de um empreendimento com os impactos ambientais negativos resultantes. Desta forma, são marcadas todas as interações, as quais são avaliadas quanto à extensão e à significância do efeito de cada ação sobre a característica ambiental considerada. Este critério de avaliação pode apresentar um alto conteúdo de subjetividade, pois baseia-se nas observações e interpretações pessoais do avaliador. 
O modelo de matriz de risco, sugerida por MOURA (1998), identifica e registra os impactos ambientais do empreendimento. Em seguida, realiza a qualificação de cada efeito ambiental negativo identificado, quanto à severidade do efeito em função da freqüência de ocorrência. Para tanto, são estabelecidas as categorias de gravidade (severidade), indicando uma medida qualitativa do pior evento que esteja ocorrendo ou com risco de ocorrer, resultantes de procedimentos inadequados, falhas e mau funcionamento de sistemas, entre outros. Estabelece-se, também, a freqüência ou probabilidade de ocorrência de impactos ambientais, determinada por pesquisa, análise e avaliação do empreendimento. A associação dos dados de freqüência com os de gravidade dos impactos ambientais, obtida pela matriz de risco, identificará as ocorrências com maior e menor expressão, subsidiando as ações para gerenciar os riscos e modificar sistemas.

Todavia, a presença de agentes químicos, nos vários ecossistemas, representa sempre um risco aos seres vivos, não existindo, praticamente o "risco zero", ou seja, $100 \%$ de segurança quando ocorre exposição a estas substâncias. Nessa perspectiva, o conceito de segurança passa a ser entendido como o julgamento ponderado da aceitabilidade de risco (GOLDSTEIN et al., 1990).

O controle da carga poluidora de efluentes líquidos industriais pode ser realizado pela identificação e caracterização de variáveis físicas e químicas, considerando os limites pré-estabelecidos pela legislação. No entanto, os 
efluentes líquidos industriais são compostos por substâncias complexas que podem interagir, dificultando a caracterização química de efluentes líquidos complexos e, não fornecendo informações sobre os efeitos tóxicos para os organismos aquáticos. Os testes de toxicidade, no entanto, fornecem informações importantes para a disposição segura de efluentes líquidos, complementado com dados analíticos (COMPANHIA DE TECNOLOGIA DE SANEAMENTO AMBIENTAL - CETESB, 1997).

A avaliação da toxicidade aguda das águas, por meio de testes de toxicidade com organismos aquáticos, constitui-se numa primeira tentativa de avaliar e alertar para um problema de qualidade ambiental de águas que recebem despejos domésticos e industriais. A CETESB vem realizando, desde 1977, testes de toxicidade com organismos aquáticos tais como peixes, microcrustáceos e algas. A escolha adequada do método a ser utilizado em cada estudo depende dos objetivos do trabalho. A utilização do microcrustáceo Daphnia similis em testes de toxicidade teve início em 1981. A sua implementação foi preconizada pelo microscrustáceo Daphnia magna, que é um organismo de regiões temperadas e considerado padrão em testes de toxicidade. O primeiro lote deste organismo foi enviado à CETESB pelo Institut National de Recherche Chimique Appliquée (IRCHA), da França, em 1978. No final deste mesmo ano foi isolada e iniciada a cultura de uma outra espécie de Daphnia, cujos exemplares foram obtidos de uma casa de aqüicultura e identificada por um especialista da Checoslováquia, Dr. J. Hrbaceck, como 
Daphnia similis. Outra cultura de Daphnia similis foi iniciada em 1981, originada de um organismo isolado de uma lagoa de estabilização da Estação de Tratamento de Esgotos da cidade de Valinhos. Após diversos testes realizados pela CETESB, foi verificado que ambas as espécies de Daphnia possuíam praticamente a mesma sensibilidade frente a substâncias químicas e a efluentes líquidos. Desta forma, deu-se continuidade aos testes para avaliação da toxicidade aguda de agentes tóxicos utilizando-se Daphnia similis, pois esta

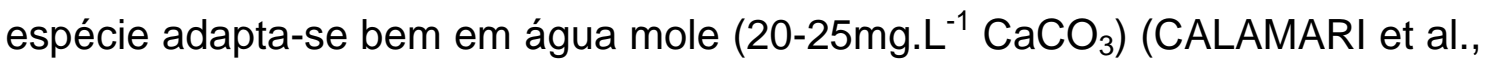
1979; MAYER et al. 1992; CETESB, 1997).

\section{I.4. OBJETIVOS}

O presente trabalho teve por finalidade desenvolver uma metodologia para a realização da avaliação de impacto ambiental, adaptada às características da indústria cerâmica de revestimento, procurando identificar os agentes impactantes do processo produtivo desde as atividades ligadas às matérias-primas até a eliminação dos efluentes líquidos e resíduos gerados, registrando seus níveis de criticalidade e fatores de risco. Com esta metodologia realizou-se um prognóstico dos aspectos ambientais do processo de fabricação, o qual auxiliou a elaboração um planejamento para monitoramento e controle dos impactos ambientais negativos identificados, atendendo aos padrões estipulados pela legislação vigente, permitindo a 
adequada gestão dos aspectos ambientais da indústria de placas de revestimento cerâmico. 


\section{CAPÍTULO II}

\section{A INDÚSTRIA DE PLACAS DE REVESTIMENTOS CERÂMICOS}

\section{II.1. PANORAMA DA INDÚSTRIA DE PLACAS DE REVESTIMENTOS CERÂMICOS NO BRASIL}

O impacto nas relações comerciais internacionais resultante da utilização maciça das normas de sistema da qualidade série ISO 9000, não deixa dúvidas de que as empresas devem se adaptar aos novos tempos. $O$ rápido crescimento do número de certificações, desde a publicação das normas de qualidade em 1987 até hoje, mostra o grau de importância da implantação de procedimentos gerenciais que garantam a qualidade. A difusão destas normas técnicas acabou por uniformizar a linguagem entre clientes e fornecedores. Assim, o mercado, cada vez mais competitivo e globalizado, ganhou agilidade e versatilidade nos negócios e nas relações comerciais.

Segundo PASCHOAL et al. (1997) a cadeia produtiva do revestimento cerâmico se constitui num setor da indústria da construção (Construbusiness) que tem uma forte presença na economia brasileira. Representando $14,8 \%$ do 
PIB brasileiro (segundo maior no ranking nacional), e empregando cerca de 13,5 milhões entre empregos diretos, indiretos e induzidos, a indústria da construção é constituída pelos setores de materiais de construção (2\% do PIB), bens de capital ( $1 \%$ do PIB), construção propriamente dita, incluindo habitações, edificações e construção pesada ( $9,8 \%$ do PIB) e serviços diversos ( $2 \%$ do PIB). O Construbusiness também possibilita um grande encadeamento com outros setores, como por exemplo as indústrias de matérias-primas, mobiliários, eletro-eletrônicos, têxtil, agentes financeiros, entre outros, aumentando ainda mais a sua importância na economia brasileira.

O setor de revestimento cerâmico brasileiro, apesar do seu grande dinamismo empresarial, no sentido de se manter atualizado tecnologicamente, tem baseado a sua estratégia de modernização na aquisição de tecnologia de processo e produto, principalmente, da Itália e Espanha. Estes dois países representam o que há de mais adiantado no estado-da-arte em revestimento cerâmico no mercado internacional, tanto em qualidade como em "design" de produto (GORINI e CORREA, 1999; PASCHOAL, 1999). Essa política de aquisição tecnológica no exterior teve, como conseqüência, um total afastamento entre esse setor e a comunidade científica e tecnológica brasileira (Universidades, Institutos de Pesquisas e outros), o que tem dificultado o estabelecimento no país de uma capacitação para inovação tecnológica, diminuindo a competitividade deste setor no mercado mundial (PASCHOAL, 1999). Analisando-se os números levantados pela Associação Nacional dos 
Fabricantes de Cerâmica para Revestimento - ANFACER, com relação a exportação de placas de revestimentos cerâmicos, e comparando-os aos principais exportadores mundiais, Itália e Espanha, nota-se que o Brasil teve um aumento pouco expressivo nas exportações no período de 1994 a 1997, de apenas 1\%, contra 40,4\% da Itália e $84 \%$ da Espanha (PASCHOAL, 1999). Em 1997, o Brasil ocupava o $4^{\circ}$ lugar como país exportador. Já os dados de 1998 revelam que a França ultrapassou o Brasil, que passou a ocupar o $5^{\circ}$ lugar, embora permaneça em $4^{\circ}$ lugar no "ranking" dos maiores países produtores de placas de revestimento cerâmico (ANFACER, 2000).

A implantação da qualidade de produto e sistema da qualidade empresarial, proporcionou ao setor uma retomada no crescimento das exportações de placas de revestimentos cerâmicos, passando de 30 milhões de $\mathrm{m}^{2}$ em 1997 para 34 milhões de $\mathrm{m}^{2}$ em 1998 (GORINI e CORREA, 1999).

\section{II.2. O PROCESSO DE FABRICAÇÃO DE PLACAS DE REVESTIMENTOS CERÂMICOS}

O revestimento cerâmico tornou-se sinônimo de higiene e exigência explícita de vários códigos da construção civil, principalmente, em ambientes como banheiros e cozinhas residenciais, de restaurantes, de lojas, de indústrias e de hospitais (PASCHOAL et al., 1997).

Esta grande difusão em aplicações bastante diversificadas do ponto de 
vista cultural, geográfico e econômico implicou em uma grande diferenciação de materiais e processos de fabricação. Como resultado destas diferenças nas características técnicas, estéticas, de custos e nas estratégias comerciais, verifica-se uma grande influência na configuração da indústria cerâmica. Além disto, as práticas no uso de materiais diversificados, utilizados no processo de fabricação, de produtos diferenciados e superiores em relação às suas qualidades intrínsecas, começaram a conflitar com os aspectos ambientais. A produção de placas de revestimentos cerâmicos apresenta impacto ambiental negativo no que se refere à emissão na atmosfera de pós e gases, a descarga de águas residuais, rejeitos e resíduos de fabricação e de tratamento (BUSANI et al., 1995; BLASCO et al., 1997).

As matérias-primas sintéticas constituem uma fonte importante de problemas ambientais, não só por serem fonte de metais tóxicos, mas também por determinarem uma série de problemas na comercialização causados, principalmente, pela falta de domínio da tecnologia para a utilização das matérias-primas sintéticas, resultando na falta de padronização de tons no produto final e gerando perdas (FIGUEIREDO FILHO et al., 1999b).

A figura 5 apresenta, esquematicamente, as etapas do processo de fabricação de placas de revestimentos cerâmicos, tanto por via seca como por via úmida. Nota-se que ambos os processos são muito semelhantes. As principais diferenças estão nos tipos de matérias-primas utilizadas e no tipo de moagem empregada. 


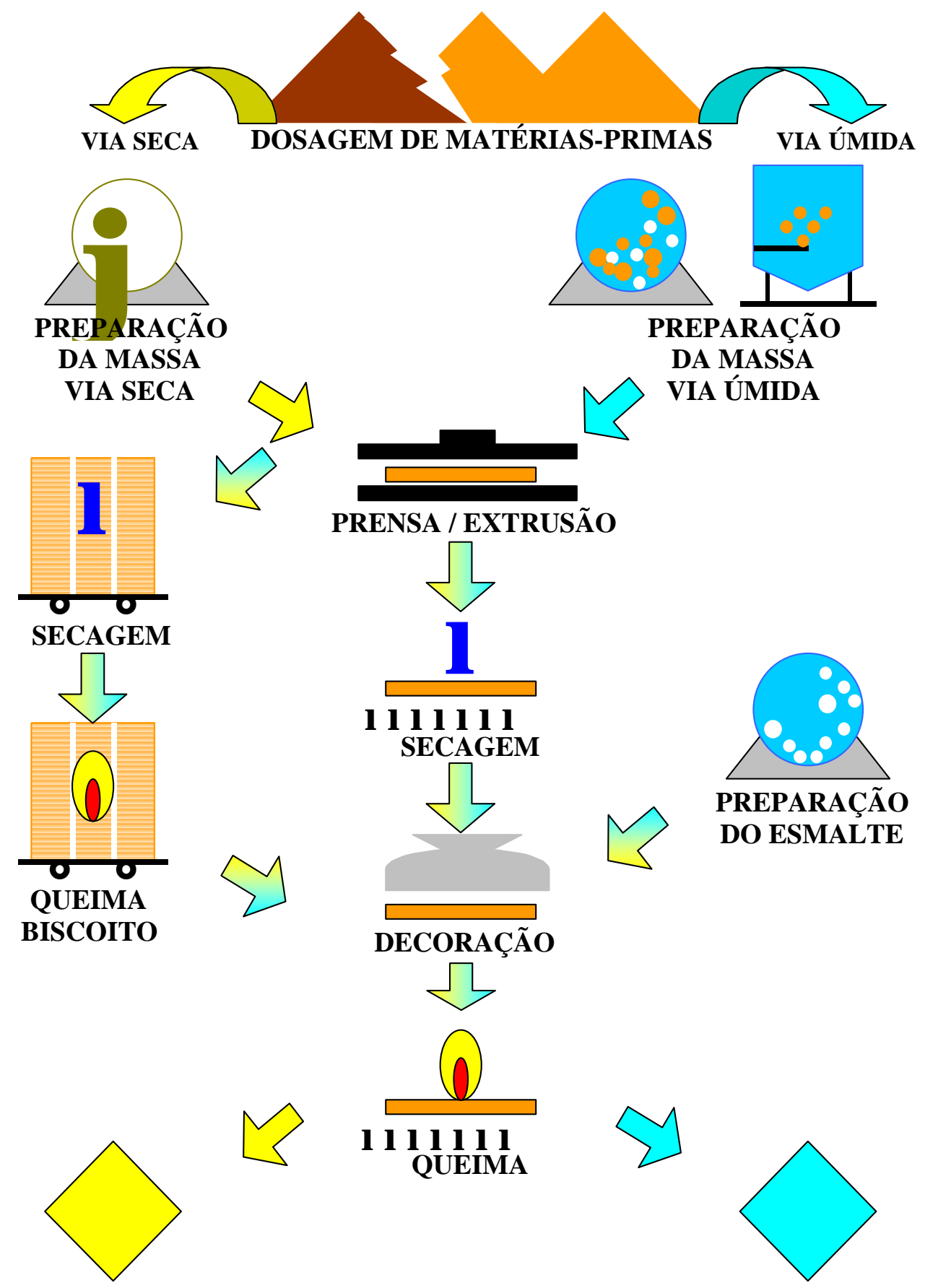

Figura 5: Representação esquemática do processo de fabricação de revestimentos cerâmicos por via úmida e por via seca. Fonte: BARBA et al, 1997 (Adaptado). 
Na via seca, a massa básica é formada pela mistura de dois ou três tipos diferentes de argilas, resultantes das alterações e "misturas" naturais associadas com a mineralogia da argila. Esta mineralogia depende intimamente das variantes geológicas ocorridas para sua gênese que, após a moagem, umidificação, prensagem e queima resultam em produtos de queima vermelha para a base produzida (COELHO, 1996; BARBA et al., 1997; BLASCO et al., 1997; MARINO, 1997).

No processo via úmida, quase sempre, a seleção de matéria-prima para a mistura busca obter uma cor de queima branca para a base produzida. 0 termo cerâmica branca está intimamente associado ao de via úmida (COELHO, 1996; BARBA et al., 1997; BLASCO et al., 1997; MARINO, 1997).

A preparação da massa cerâmica no "Processo Via Úmida", envolve a mistura de várias matérias-primas tais como filito, talco, calcita e alguns tipos de argilas plásticas e não plásticas. Em média, o consumo diário de matériasprimas naturais nas indústrias de revestimento cerâmico chega a 478 mil quilos $^{(1)}$ para uma produção de mais de $7.000 \mathrm{~m}^{2}{ }^{(1)}$. Algumas indústrias adicionam a esta formulação até $10 \%$ de material recuperado nas prensas (peças verdes quebradas) e nos tanques de decantação das linhas de decoração (resíduos de esmaltes e corantes) ${ }^{(1)}$.

\footnotetext{
${ }^{1}$ Dados obtidos em indústria de revestimento cerâmico de médio porte
} 
A esta composição é adicionado um defloculante e, o conjunto, vai para os moinhos, cuja capacidade individual é entre 15 e 20 mil quilos ${ }^{(1)}$. A moagem desta formulação da massa do corpo cerâmico é efetuada em meio aquoso, por um período que varia de cinco a seis horas, promovendo a interação mais efetiva entre os diversos componentes da massa. Em seguida, esta massa líquida, denominada barbotina, é depositada em tanques com capacidade média de 100 mil litros cada um ${ }^{(1)}$, e então é homogeneizada e passada em peneiras para a retirada de grãos mais grosseiros, geralmente acima de 325 mesh ${ }^{(1)}$. O padrão utilizado para o controle de qualidade referente a porcentagem de resíduo retido na peneira é de $9,5 \pm 0,5 \%{ }^{(1)}$. A massa de barbotina, com características consideradas dentro das condições normais no controle de qualidade, deve apresentar $150 \pm 50 \mathrm{cp}$ de viscosidade e densidade aparente $1,70 \pm 0,20 \mathrm{~g} \cdot \mathrm{cm}^{-3(1)}$.

Atendendo às especificações do controle de qualidade, a barbotina é bombeada para a parte superior do atomizador onde, por um bico dosador, esta massa líquida é borrifada entrando em contato com o ciclone de ar quente a uma temperatura de, aproximadamente, $150^{\circ} \mathrm{C}{ }^{(1)}$. Desta forma ocorre a secagem e a granulação da massa, cuja umidade varia de 6,3 a 6,8\% ${ }^{(1)}$.

Esta massa atomizada segue para prensagem. O conjunto de prensas pode produzir cerca de $7 \mathrm{mil}^{2}$ de peças por dia ${ }^{(1)}$. Em condições normais de produção pode ocorrer cerca de $5 \%$ de quebra de peças, porém, o resíduo gerado nas prensas retorna à massa antes da moagem ${ }^{(1)}$. As peças assim 
produzidas seguem para o secador, no qual permanecerão por um período de uma hora sob a temperatura de $100^{\circ} \mathrm{C}$, perdendo cerca de $80 \%$ da umidade contida na peça ${ }^{(1)}$. Após a secagem, as peças seguem para a linha de decoração.

Para a decoração das peças cerâmicas, as massas de decoração devem ser preparadas. Este procedimento é realizado pela mistura de diferentes tipos de insumos tais como esmaltes, fritas, corantes e argilas, feldspatos, carbonatos, entre outros minerais. A fabricação destes insumos é realizada pelo colorifício. É comum, também, o colorifício prestar serviço no que concerne ao desenvolvimento de cores, estamparias e outros serviços relativos à decoração personalizada para cada indústria de revestimento cerâmico da qual é fornecedor ${ }^{(1)}$.

$\mathrm{Na}$ indústria cerâmica estes insumos são misturados, de acordo com a formulação pré-estabelecida, e moídos juntamente com um defloculante. A capacidade dos moinhos para preparação das massas de decoração varia muito, podendo ser de 500 quilos ou 12 mil quilos ${ }^{(1)}$, pois a produção dos tipos de massas de decoração irá depender do "design" estabelecido para cada lote de peças cerâmicas a ser produzido. O consumo diário destes insumos pode ser superior a 10 mil quilos ${ }^{(1)}$. Após a moagem as massas de decoração são armazenadas em tanques com capacidades que podem variar de 2 mil litros até 12 mil litros ${ }^{(1)}$. O abastecimento da linha de decoração ocorre por meio de recipientes denominados vascas. Para a decoração de $1000 \mathrm{~m}^{2}$ de peças são 
necessárias cerca de quatro vascas ${ }^{(1)}$. O custo destas matérias-primas chega a ser mais de 20 vezes maior do que o custo das matérias-primas naturais ${ }^{(1)}$.

O processo de decoração é, basicamente, a aplicação da camada de engobe e camadas de massas de decoração, que geralmente são aplicadas com telas serigráficas, com diferentes estampas, promovendo, no produto final, a característica estética desejada, em cores e texturas. O tempo de duração da etapa de decoração é, em média, de uma hora. Os efluentes líquidos resultantes das lavagens das linhas de decoração, das vascas, moinhos e tanques da preparação das massa de decoração, são coletados em tanques de decantação. Os tanques são projetados de acordo com o volume de efluentes líquidos gerados, além da quantidade de sólidos em suspensão neles presentes. Em alguns casos, tanques com capacidade total de $4,5 \mathrm{~m}^{3}$ já atendem às necessidades de retenção dos efluentes líquidos gerados, em outros casos é necessário um volume total de $40 \mathrm{~m}^{3}$ para atingir esta finalidade (1). O consumo mensal de água no processo de fabricação de revestimento cerâmico, pode chegar a mais de 7 milhões de litros ${ }^{(1)}$.

Após a decoração, as peças seguem para a etapa de queima. A queima das peças cerâmicas, tanto por via seca como por via úmida, pode ser de dois tipos:

- Monoqueima: a sinterização do corpo cerâmico, a vitrificação dos esmaltes e estabilização das cores ocorrem numa única etapa, ou 
- Biqueima: a sinterização das peças a verde ocorre antes da decoração, formando o biscoito e, após a decoração, as peças passam por uma segunda queima, a qual vitrifica os esmaltes e estabiliza as cores. (COELHO, 1996; BARBA et al., 1997; MARINO, 1997).

Nos fornos, a permanência é de 55 minutos ${ }^{(1)}$, incluindo préaquecimento, queima e resfriamento. A temperatura na região de queima está entre 1100 a $1200^{\circ} \mathrm{C}^{(1)}$. A produção diária de um forno é cerca de $7.200 \mathrm{~m}^{2}$ de peças ${ }^{(1)}$. Em média, 0,6\% das peças produzidas em um mês são perdidas devido a quebras após a queima ${ }^{(1)}$.

\section{II.2.1. Matérias-Primas Naturais}

As matérias-primas naturais utilizadas para a fabricação de placas de revestimentos cerâmicos podem ser classificadas de plásticas e não-plásticas. Embora ambas exerçam funções ao longo de todo o processo cerâmico, as matérias-primas plásticas são essenciais na fase de conformação, enquanto que as não-plásticas atuam mais na fase do processamento térmico. As principais matérias-primas plásticas utilizadas no preparo das massas de placas de revestimentos cerâmicos são argilas plásticas (queima branca ou clara) e caulim e argilas fundentes (queima vermelha). Dentre as matériasprimas não-plásticas destacam-se os filitos, fundentes feldspáticos (feldspato, granito, sienito entre outros), talco e carbonatos (calcário, dolomito), sendo que 
o filito e o talco apresentam também características plásticas (MOTTA et al. apud TOMI et al., 1999).

De todos os estágios deste processo de produção, o de queima é o mais importante. Aliado a ele está a composição da massa do corpo cerâmico, pois as interações entre os diferentes componentes da massa ocorridas durante 0 tratamento térmico irá determinar as características do produto final (NORTON, 1973; BARBA et al., 1997; MARINO, 1997).

Durante o processo de queima da peça cerâmica, os fundentes aceleram a formação dos materiais vítreos que recobrirão uma certa quantidade de poros, resultando num produto com qualidades intrínsecas melhores, como por exemplo maior estanqueidade à água, maior resistência mecânica entre outras melhorias (NORTON, 1973). É comum a adição de fundentes para a formação de um corpo cerâmico compacto e melhoria de algumas qualidades intrínsecas do produto final. Porém, é importante salientar que as quantidades devem ser controladas, pois uma vez que os poros são fechados podem gerar tensões internas no material resultando no surgimento de trincas e, conseqüentemente, diminuindo a resistência mecânica do corpo cerâmico. Podem, também, resultar em alterações dimensionais, como retração causada pela aproximação das partículas (NORTON, 1973; SANTOS, 1975).

As matérias-primas não plásticas (feldspatos, feldspatóides, quartzo, carbonatos, talcos, entre outros) atuam reduzindo a plasticidade e facilitando a 
defloculação da barbotina. Além disso, aumentam o tamanho do poro, e portanto, a permeabilidade da peça, facilitando a secagem e a desgaseificação durante o pré-aquecimento. Proporcionam, ainda, uma série de óxidos que durante a queima podem reagir com o restante dos componentes ou permanecerem inertes, trazendo diferentes propriedades ao produto. Os óxidos originados da decomposição dos carbonatos são capazes de reagir com a sílica e com a alumina, provenientes da desidroxilação dos argilominerais para formar fases cristalinas estáveis (MOTTA et al. apud TOMI et al., 1999).

Os feldspatos, normalmente sódicos e/ou potássicos, ao fundirem proporcionam as primeiras fases líquidas, diminuindo a temperatura de queima. O papel do talco é muito semelhante ao dos feldspatos, sendo utilizado para favorecer a fusão das massas cerâmicas ao formar misturas eutéticas com as demais matérias-primas habitualmente utilizadas. O quartzo atua como inerte, aumentando a refratariedade da composição e seu coeficiente de dilatação, diminuindo a contração da queima (SANTOS, 1975; MOTTA et al. apud TOMI et al., 1999).

Todo cristal tem associado uma estrutura cristalina ou um reticulado uniforme com uma unidade repetida (célula unitária) regularmente em todas as direções, enquanto a estrutura do material vítreo é caracterizado por um reticulado irregular, variando aleatoriamente com apenas o tetraedro silíciooxigênio, com a unidade quase invariável. Neste reticulado, ao acaso, existem vazios de vários tamanhos nos quais podem se localizar outros íons tais como 
$\mathrm{Ca}^{2+} ; \mathrm{Ba}^{2+} ; \mathrm{Li}^{+} ; \mathrm{Na}^{+} ; \mathrm{K}^{+} ; \mathrm{Rb}^{+} ; \mathrm{Cs}^{+} ; \mathrm{Pb}^{2+}$, denominados modificadores. Os modificadores não podem formar material vítreo, mas ao entrarem nos interstícios do reticulado do material vítreo, enfraquecendo as ligações, provocam a diminuição da temperatura de fusão dos vidrados. Por facilitarem a fusão do material vítreo, estes cátions são denominados fundentes. Outro grupo de óxidos, formados pelos cátions $\mathrm{Ti}^{4+} ; \mathrm{S}^{4+} ; \mathrm{Zr}^{4+} ; \mathrm{Al}^{3+}$, por si só não podem formar material vítreo, mas são capazes de substituir isomorficamente o $\mathrm{Si}^{4+}$, sendo então conhecidos como íons intermediários. Os cátions $\mathrm{Fe}^{3+} ; \mathrm{Be}^{2+}$; $\mathrm{Mg}^{2+} ; \mathrm{Ni}^{2+} ; \mathrm{Zn}^{2+} ; \mathrm{Fe}^{2+}$, se comportam parcialmente como formadores de material vítreo e parcialmente como modificadores (KIRSCH, 1972; NORTON, 1973).

Porém, este comportamento térmico está intimamente relacionado com outras variáveis. A temperatura e intensidade de reação estão diretamente relacionadas, por exemplo, com o tamanho das partículas e a cristalinidade dos argilominerais. Os picos de um termograma serão da ordem de $20^{\circ} \mathrm{C}$ ou $30^{\circ} \mathrm{C}$ menos intensos na caulinita mal cristalizada (ou com defeitos) do que nas bem cristalizadas. Segundo NORTON (1973), a seqüência de reações pode ser representada da seguinte maneira: 


\section{CERÂMICOS}

$\mathrm{Al}_{2} \mathrm{O}_{3} \cdot 2 \mathrm{SiO}_{2} \cdot 2 \mathrm{H}_{2} \mathrm{O}$

Caulinita

$2\left[\mathrm{Al}_{2} \mathrm{O}_{3} \cdot 2 \mathrm{SiO}_{2}\right]$

Metacaulinita

$2 \mathrm{Al}_{2} \mathrm{O}_{3} \cdot 3 \mathrm{SiO}_{2}$

Espinélio $\mathrm{Al}: \mathrm{Si}$

$3\left[\mathrm{Al}_{2} \mathrm{O}_{3} \cdot \mathrm{SiO}_{2}\right]$

Mulita 1:1 $\overrightarrow{500{ }^{\circ} \mathrm{C}}$

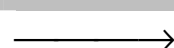

$925^{\circ} \mathrm{C}$

$\longrightarrow$

$1100^{\circ} \mathrm{C}$

Acima de $1400{ }^{\circ} \mathrm{C}$
$\mathrm{Al}_{2} \mathrm{O}_{3} \cdot 2 \mathrm{SiO}_{2}+2 \mathrm{H}_{2} \mathrm{O}$

Metacaulinita

$2 \mathrm{Al}_{2} \mathrm{O}_{3} \cdot 3 \mathrm{SiO}_{2}+\mathrm{SiO}_{2}$

Espinélio $\mathrm{Al}: \mathrm{Si}$

$2\left[\mathrm{Al}_{2} \mathrm{O}_{3} \cdot \mathrm{SiO}_{2}\right]+\mathrm{SiO}_{2}$ Mulita $1: 1+$ Cristobalita

$3 \mathrm{Al}_{2} \mathrm{O}_{3} \cdot 2 \mathrm{SiO}_{2}+\mathrm{SiO}_{2}$

Mulita 3:2 + Cristobalita

A variação dos constituintes da massa do corpo cerâmico influi na qualidade do produto final. Fazendo-se uma rápida analogia, verifica-se que esta influência começa com a concentração dos compostos majoritários, a alumina $\left(\mathrm{Al}_{2} \mathrm{O}_{3}\right)$ e a sílica $\left(\mathrm{SiO}_{2}\right)$. Pequenas variações de uma matéria-prima para outra indicam propriedades cerâmicas diferentes. A variação quantitativa destes elementos está associada com a mineralogia da argila, a qual depende intimamente das variantes geológicas ocorridas durante sua gênese. A presença de ferro e titânio na composição dos minerais pode proporcionar características positivas (catalisar a ação dos fundentes) ou negativas (surgimentos de manchas escuras na peça acabada), dependendo das concentrações apresentadas. Os níveis de metais alcalinos e alcalinos terrosos, como já observado, representam um papel importantíssimo como fundentes, como é o caso do sódio e do potássio, influindo na resistência mecânica do produto final. O cálcio e o magnésio podem ser indicadores da presença de carbonatos que, devido a liberação de $\mathrm{CO}_{2}$, podem aumentar a porosidade do material. Eles influenciam também na estabilidade dimensional das placas de revestimentos cerâmicos (NORTON, 1973; SANTOS, 1975). 
Por meio de diversas ferramentas analíticas foi possível acompanhar o comportamento destes materiais durante a etapa de queima, identificando as alterações mineralógicas e as contribuições na qualidade do produto final. Estes dados, sob o ponto de vista ambiental, também contribuem para a avaliação do processo produtivo, pois eles revelam a eficiência de queima dos fornos, podendo ser controlado o uso de insumos energéticos evitando perdas, além de proporcionarem a produção de peças de maior qualidade, diminuindo também as perdas provocadas por quebra das peças cerâmicas e, conseqüentemente, dos insumos utilizados para a fabricação das mesmas.

\section{II.2.2. Matérias-Primas Sintéticas}

A decoração é realizada pela aplicação de finas camadas de uma suspensão aquosa, obtida pela moagem das fritas e seus componentes principais, que cobrem a superfície das peças que podem estar previamente queimadas (processo de biqueima) ou ainda cruas (processo de monoqueima) (AMARANTE Jr., 1995; MENDES et al., 1995; SANTOS, 1995). O termo esmalte se refere a todas as coberturas vítreas altamente opacas devido à presença de silicato de zircônio, óxido de titânio e óxido de estanho. Já a frita (material vítreo fundido) é um tipo especial de esmalte denominado "frita transparente", que é empregado em camadas finas sobre as decorações e o esmalte, proporcionando brilho à peça cerâmica. Segundo NORTON (1973), este material vítreo é composto, basicamente, de carbonato de chumbo, 


\section{CERÂMICOS}

carbonato de cálcio, fundentes, caulim e quartzo. As fritas também podem ser utilizadas como veículo de constituintes corantes, permitindo a obtenção de uma variedade maior de texturas e superfícies coloridas à peça cerâmica (NORTON, 1973; AMARANTE Jr., 1995; MENDES et al., 1995; SANTOS, 1995).

Os corantes são, normalmente, os óxidos de ferro, de cobalto, de manganês, de cobre, de cádmio, de chumbo e de selênio. Antes da adição do esmalte é comum a adição de misturas compostas de massa do corpo cerâmico com material vítreo, cuja função é proporcionar a aderência do esmalte ao suporte, minimizar os defeitos ocasionados pelos diferentes comportamentos térmicos do corpo cerâmico e do esmalte, entre outros. A esta composição dá-se o nome de engobe, que também tem função opacificante, proporcionando o recobrimento das imperfeições do corpo cerâmico impedindo que elas interfiram na camada de decoração (ALBARO, 1993; AMARANTE Jr., 1995; MENDES et al., 1995; SANTOS, 1995; PASCHOAL et al., 1997;).

Os constituintes básicos dos esmaltes cerâmicos são:

a) Agentes vitrificantes $-\mathrm{SiO}_{2} ; \mathrm{B}_{2} \mathrm{O}_{3}$

b) Fundentes - $\mathrm{Na}_{2} \mathrm{O} ; \mathrm{K}_{2} \mathrm{O} ; \mathrm{PbO} ; \mathrm{B}_{2} \mathrm{O}_{3} ; \mathrm{Li}_{2} \mathrm{O}$

c) Estabilizadores - $\mathrm{CaO} ; \mathrm{BaO} ; \mathrm{MgO} ; \mathrm{PbO} ; \mathrm{Al}_{2} \mathrm{O}_{3} ; \mathrm{ZnO}$

d) Opacificantes - $\mathrm{ZrO}_{2} ; \mathrm{SnO}_{2} ; \mathrm{TiO}_{2}$

e) Devitrificantes - ZnO; $\mathrm{CaO}$; $\mathrm{BaO} ; \mathrm{MgO}_{\mathrm{TiO}_{2}}$ 
Das etapas que compreendem o processo de fabricação de placas revestimentos cerâmicos, tanto por via seca como por via úmida, as fases de preparação de tintas e vidrados (PTV) e de decoração, seja por monoqueima ou por biqueima, produzem resíduos e efluentes com características tóxicas, devido à composição das matérias-primas sintéticas utilizadas (BURZACCHINI, 1991; COELHO, 1996; BARBA et al., 1997; MARINO, 1997). 


\section{CAPÍTULO III}

\section{METODOLOGIA}

\section{III.1. PROGNÓSTICO DOS ASPECTOS AMBIENTAIS}

\section{III.1.1. Desenvolvimento da Metodologia de Avaliação de Impactos Ambientais}

\section{III.1.1.1. Caracterização do Processo Produtivo}

Para o desenvolvimento da metodologia de avaliação de impactos ambientais, foi importante o conhecimento do processo produtivo e suas peculiaridades, afim de que os critérios de avaliação que seriam estipulados fossem compatíveis com os riscos e a complexidade das instalações avaliadas.

Para a caracterização preliminar das etapas do processo de fabricação de placas de revestimentos cerâmicos foram aplicados alguns métodos de avaliação. Nesta etapa realizou-se a identificação dos resíduos gerados, a freqüência que são produzidos e a gravidade, para que posteriormente fossem definidos os critérios para hierarquização das etapas do processo produtivo 
quanto ao seu efeito poluidor. Além destes aspectos, deve-se ressaltar que estas metodologias passaram também a ser empregadas como instrumentos para o planejamento analítico do monitoramento das atividades e para nortear as ações propostas para minimização dos impactos ambientais negativos na indústria de placas de revestimentos cerâmicos.

\section{III.1.1.2. Identificação dos Aspectos Ambientais}

Para a identificação dos aspectos ambientais, foi elaborada uma planilha relacionando as etapas do processo produtivo com o tipo de resíduo gerado, adaptando-se o modelo utilizado por BRAGA et al. (1996). Para cada etapa foi elaborada uma planilha, obtendo-se assim uma análise pormenorizada do processo produtivo (Apêndice 1). Após a seleção e hierarquização das etapas do sistema produtivo, de acordo com o tipo e o volume de resíduo gerado, fezse a identificação e a seleção de normas da Associação Brasileira de Normas Técnicas - ABNT. Estas Normas determinam as metodologias de amostragem, caracterizações, monitoramento e tratamento dos resíduos sólidos e efluentes líquidos e gasosos (TAB.1; 2). Também foram selecionados os diplomas legais federal e estadual pertinentes aos tipos de resíduos gerados, (TAB.3; $4 ; 5 ; 6)$. 
Tabela 1: Exemplo de planilha de detalhamento dos aspectos ambientais e processos tecnológicos - Normas - ABNT ${ }^{(2)}$ das atividades da etapa de preparação da massa do corpo cerâmico - Monoqueima

Fonte: Modelo planilha adaptada de BRAGA et al., 1996; Normas fonte ANBT, 1995.

\begin{tabular}{|c|c|c|c|c|c|}
\hline \multirow{3}{*}{$\begin{array}{cc} & \begin{array}{c}\text { Processo de } \\
\text { Fabricação }\end{array} \\
\text { Tipo de } & \end{array}$} & \multicolumn{5}{|c|}{ 1. MONOQUEIMA } \\
\hline & \multicolumn{5}{|c|}{1.1 SETOR DE PREPARACÁO DA MASSA DO CORPO DO REVESTIMENTO CERÁMICO } \\
\hline & 1.1 .1 & 1.1 .2 & 1.1 .3 & 1.1 .4 & 1.1 .5 \\
\hline Resíduo gerado & depósito & balança/formulação massa & esteira & moagem & peneiramento \\
\hline \multirow{6}{*}{ SÓLIDOS } & NBR10004 & NBR 10004 & & NBR10004 & \multirow{4}{*}{ NBR 10007} \\
\hline & NBR 10005 & NBR 10005 & & NBR 10005 & \\
\hline & NBR 10006 & NBR 10006 & & NBR 10006 & \\
\hline & NBR 10007 & NBR 10007 & & NBR 10007 & \\
\hline & NBR 11174 & NBR 11174 & & NBR 11174 & NBR 11174 \\
\hline & NBR 13463 & NBR 13463 & & NBR 13463 & NBR 13463 \\
\hline \multirow{9}{*}{ LÍQUIDOS } & & & & NBR 9800 & \\
\hline & & & & NBR 9897 & \\
\hline & & & & NBR 9898 & \\
\hline & & & & NBR 10561 & \\
\hline & & & & NBR 10664 & \\
\hline & & & & NBR 12988 & \\
\hline & & & & NBR 13035 & \\
\hline & & & & NBR 13042 & \\
\hline & & & & NBR 13403 & \\
\hline \multirow{4}{*}{ PARTÍCULAS SUSPENSÃO } & NBR 9547 & NBR 9547 & NBR 9547 & & \\
\hline & NBR 10736 & NBR 10736 & NBR 10736 & & \\
\hline & NBR12065 & NBR12065 & NBR12065 & & \\
\hline & NBR 12085 & NBR 12085 & NBR 12085 & & \\
\hline \multicolumn{6}{|l|}{ GASES DE EXAUSTÃO } \\
\hline PEÇAS QUEBRADAS & & & & & \\
\hline
\end{tabular}

${ }^{2}$ Títulos NBR Tabela 2 
Tabela 2: Relação de algumas das normas da ABNT - Associação Brasileira de Normas Técnicas relativas às metodologias de coleta e preservação de amostras, ensaios e classificação aplicáveis à poluição do ar, solo e líquidos (ABNT,1995).

\begin{tabular}{|c|c|}
\hline \multicolumn{2}{|r|}{ AR } \\
\hline NBR - 9546 & $\begin{array}{l}\text { Dióxido de enxofre no ar ambiente - determinação da concentração - método de } \\
\text { ensaio }\end{array}$ \\
\hline NBR - 9547 & $\begin{array}{l}\text { Material particulado em suspensão no ar ambiente - determinação da } \\
\text { concentração total pelo método do amostrador de volume - método de ensaio }\end{array}$ \\
\hline NBR - 10700 & $\begin{array}{l}\text { Planejamento de amostragem em dutos e chaminés de fontes estacionárias - } \\
\text { procedimentos. }\end{array}$ \\
\hline NBR - 10736 & $\begin{array}{l}\text { Material particulado em suspensão na atmosfera - determinação da concentração } \\
\text { de fumaça pelo método de refletância da luz - método de ensaio }\end{array}$ \\
\hline NBR - 12065 & $\begin{array}{l}\text { Atmosfera - determinação da taxa de poeira sedimentável total - método de } \\
\text { ensaio }\end{array}$ \\
\hline NBR - 12085 & $\begin{array}{l}\text { Agentes químicos no ar - coleta de aerodispersóides por filtração - método de } \\
\text { ensaio }\end{array}$ \\
\hline NBR - 12979 & $\begin{array}{l}\text { Atmosfera - determinação da concentração de dióxido de enxofre pelo método do } \\
\text { peróxido de hidrogênio - método de ensaio. }\end{array}$ \\
\hline NBR - 13157 & $\begin{array}{l}\text { Atmosfera - determinação da concentração de monóxido de carbono por } \\
\text { espectrofotometria de infravermelho não dispersivo - método de ensaio. }\end{array}$ \\
\hline \multicolumn{2}{|r|}{ SOLO } \\
\hline NBR - 10004 & Resíduos sólidos - classificação \\
\hline NBR -10005 & Lixiviação de resíduos - procedimento \\
\hline NBR - 10006 & Solubilização de resíduos - procedimento \\
\hline NBR -10007 & Amostragem de resíduos - procedimento \\
\hline NBR - 11174 & Armazenamento de resíduos classe II (não inertes) e III (inertes) - procedimento. \\
\hline NBR -13463 & Coleta de resíduos sólidos - classificação \\
\hline \multicolumn{2}{|r|}{ LÍQUIDO } \\
\hline NBR -9800 & $\begin{array}{l}\text { Critérios para lançamento de efluentes líquidos industriais no sistema coletor } \\
\text { público de esgotos sanitários. }\end{array}$ \\
\hline NBR - 9897 & $\begin{array}{l}\text { Planejamento de amostragem de efluentes líquidos e corpos receptores - } \\
\text { procedimento }\end{array}$ \\
\hline NBR - 9898 & $\begin{array}{l}\text { Preservação e técnicas de amostragem de efluentes líquidos e corpos receptores } \\
\text { - procedimento }\end{array}$ \\
\hline NBR - 10561 & $\begin{array}{l}\text { Águas - determinação de resíduo sedimentável (sólidos sedimentáveis) - método } \\
\text { do cone imhoff }\end{array}$ \\
\hline NBR - 10664 & Água - determinação de resíduos (sólidos) - método gravimétrico \\
\hline NBR - 12988 & ãa em amostras de resíduos - método de ensaio. \\
\hline NBR - 13035 & $\begin{array}{l}\text { Planejamento e instalação de laboratórios para análises e controle de águas - } \\
\text { procedimento }\end{array}$ \\
\hline 13042 & $\begin{array}{l}\text { Caracterização de cargas poluidoras em efluentes líquidos industriais e } \\
\text { domésticos - procedimento }\end{array}$ \\
\hline NBR - 13403 & $\begin{array}{l}\text { Medição de vazão em efluentes líquidos e corpos receptores - escoamento livre - } \\
\text { procedimento }\end{array}$ \\
\hline
\end{tabular}

Fonte: Associação Brasileira de Normas Técnicas (ABNT 1995) 
Tabela 3: Exemplo de planilha de detalhamento dos aspectos ambientais e processos tecnológicos - Diplomas Legais Federal $^{(3)}$ das atividades da etapa de preparação da massa do corpo cerâmico.

Fonte: Modelo planilha adaptada de BRAGA et al., 1996; Diplomas Legais Federal BRASIL, 1986; BRASIL, 1990a; BRASIL, $1990 \mathrm{~b}$ BRASIL, 1993.

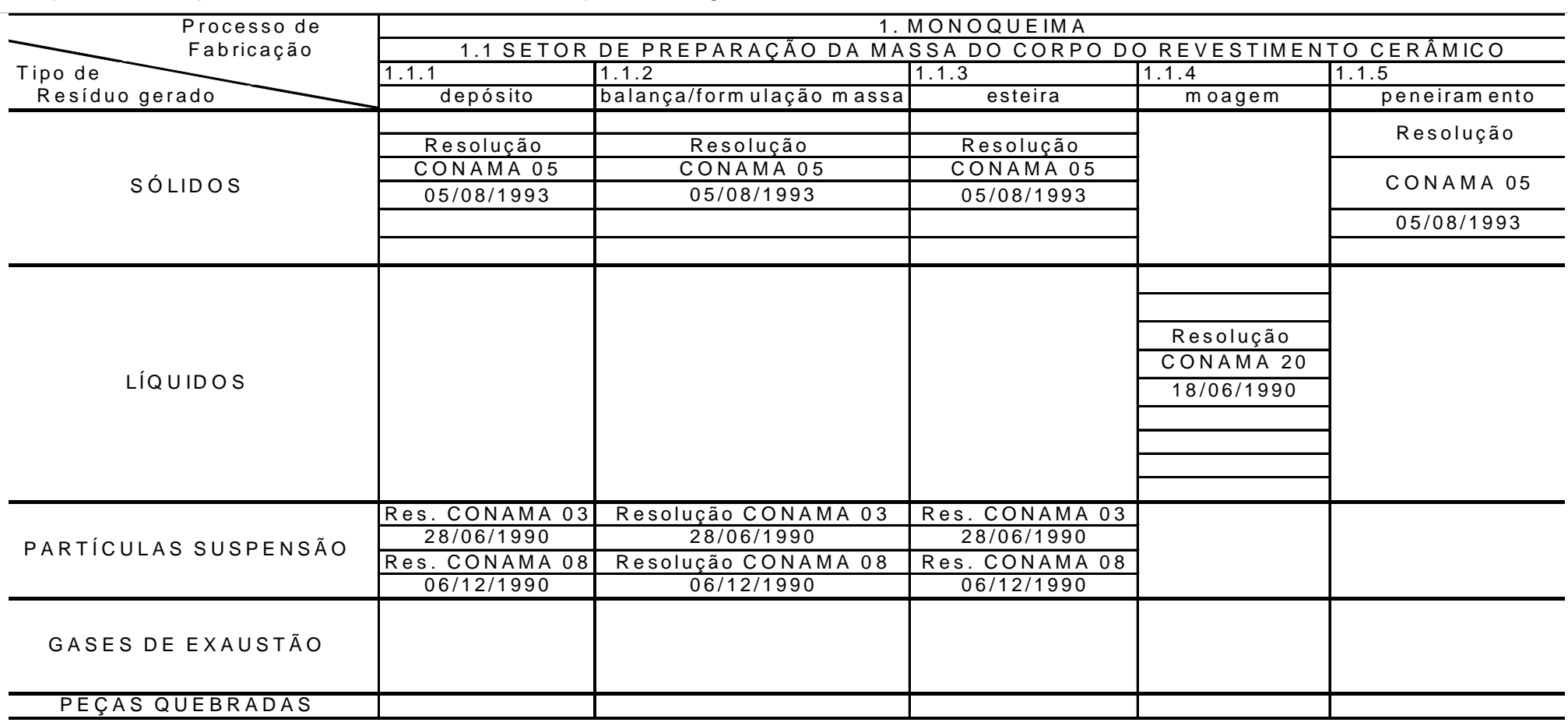

\footnotetext{
${ }^{3}$ Títulos Resoluções CONAMA Tabela 4
} 
Tabela 4: Legislação Federal - resoluções CONAMA sobre controle de poluição ambiental.

\begin{tabular}{|c|c|c|}
\hline \multicolumn{2}{|c|}{ Resolução CONAMA } & \multirow{2}{*}{ Descrição } \\
\hline Número & Data & \\
\hline 20 & $18 / 06 / 1986$ & $\begin{array}{l}\text { Classifica águas doces, salobras e salinas do Território } \\
\text { Nacional em nove classes, segundo seus usos } \\
\text { preponderantes (Esta resolução revogou as Portarias } \\
\text { MINTER } n^{\circ} 0013 \text {, de } 15 / 01 / 76 \text {, e } 536 \text {, de } 07 / 12 / 76 \text { ). }\end{array}$ \\
\hline 03 & $28 / 06 / 1990$ & $\begin{array}{l}\text { Estabelece os Padrões de Qualidade do Ar (Publicada } \\
\text { no D.O U. de 16/08/90, pág. 15.518). }\end{array}$ \\
\hline 08 & 06/12/1990 & $\begin{array}{l}\text { Estabelece limites máximos de emissão de poluentes } \\
\text { do ar para processos de combustão externa em fontes } \\
\text { novas fixas como: caldeiras, geradores de vapor, } \\
\text { centrais para a geração de energia elétrica, fornos, } \\
\text { fornalhas, estufas e secadores para geração e uso de } \\
\text { energia térmica, incineradores e gaseificadores. }\end{array}$ \\
\hline 05 & 05/08/1993 & $\begin{array}{l}\text { Dispõe sobre a destinação final de Resíduos Sólidos. } \\
\text { Define normas mínimas para tratamento de resíduos } \\
\text { sólidos oriundos de serviços de saúde, portos e } \\
\text { aeroportos. Estende exigências aos terminais } \\
\text { rodoviários e ferroviários. Define: Resíduos Sólidos, } \\
\text { Plano de Gerenciamento, Sistema de Tratamento, } \\
\text { Sistema de Disposição Final. Classificação de resíduos } \\
\text { GRUPO A - Presença de agentes biológicos; GRUPO } \\
\text { B - Características químicas; GRUPO C - Rejeitos } \\
\text { radioativos; GRUPO D - Resíduos comuns que não se } \\
\text { enquadrem nos demais grupos. }\end{array}$ \\
\hline
\end{tabular}

Fonte: BRASIL, 1986; BRASIL, 1990a; BRASIL, 1990b e BRASIL, 1993. 
Tabela 5: Exemplo de planilha de detalhamento dos aspectos ambientais e processos tecnológicos - Diplomas Legais Estadual $^{(4)}$ das atividades da etapa de preparação da massa do corpo cerâmico.

Fonte: Modelo planilha adaptada de BRAGA et al., 1996; Diplomas Legais Estadual SÃO PAULO, 1976 (a, b, c, d, e, f); SÃO PAULO, 1977.

\begin{tabular}{|c|c|c|c|c|c|}
\hline \multirow{4}{*}{ 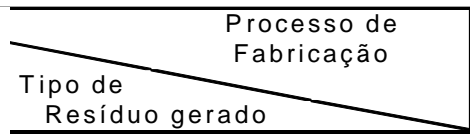 } & \multicolumn{5}{|c|}{ 1. MONOQUEIMA } \\
\hline & \multicolumn{5}{|c|}{1.1 SETOR DE PREPARAÇÃO DA MASSA DO CORPO DO REVESTIMENTO CERÁMICO } \\
\hline & 1.1 .1 & 1.1 .2 & 1.1 .3 & 1.1 .4 & 1.1 .5 \\
\hline & depósito & balança/formulação massa & esteira & moagem & peneiramento \\
\hline \multirow{4}{*}{ SÓLIDOS } & DECRETO no & DECRETO no. & DECRETO no. & & DECRETO no. \\
\hline & 8.468 & 8.468 & 8.468 & & 8.468 \\
\hline & Título IV & Título IV & Título IV & & Título IV \\
\hline & de $08 / 09 / 1976$ & de $08 / 09 / 1976$ & de $08 / 09 / 1976$ & & de $08 / 09 / 1976$ \\
\hline \multirow{8}{*}{ LÍQUIDOS } & & & & DECRETO no. & \\
\hline & & & & 10.755 & \\
\hline & & & & $22 / 11 / 1977$ & \\
\hline & & & & DECRETO no. & \\
\hline & & & & 8.468 & \\
\hline & & & & Art. 7o e & \\
\hline & & & & Seção II, Art. 18 & \\
\hline & & & & de $08 / 09 / 1976$ & \\
\hline \multirow{4}{*}{ PARTÍCULAS SUSPENSÃO } & DECRETO no. & DECRETO no. & DECRETO no. & & \\
\hline & 8.468 & 8.468 & 8.468 & & \\
\hline & Anexos 6 e 8 & Anexos 6 e 8 & Anexos 6 e 8 & & \\
\hline & $08 / 09 / 1976$ & $08 / 09 / 1976$ & $08 / 09 / 1976$ & & \\
\hline \multicolumn{6}{|l|}{ GASES DE EXAUSTÃO } \\
\hline PEÇAS QUEBRADAS & & & & & \\
\hline
\end{tabular}

${ }^{4}$ Títulos Legislação Estadual Tabela 6 
Tabela 6: Legislação Estadual - Decretos sobre controle de poluição ambiental do Estado de São Paulo.

\begin{tabular}{|c|c|c|}
\hline \multicolumn{2}{|c|}{ Decreto } & \multirow{2}{*}{ Descrição } \\
\hline Número & Data & \\
\hline $\begin{array}{c}8.468 \\
\text { Anexo } 6\end{array}$ & 08/09/76 & $\begin{array}{l}\text { Dispõe sobre os padrões de emissão para material } \\
\text { particulado - Padrão de Emissão (PE) a que se } \\
\text { refere o Art. } 33-A \text {, acrescentado pelo Art. } 6^{\circ} \text { do } \\
\text { Decreto } n^{\circ} 15.425 \text { de } 23 / 07 / 80\end{array}$ \\
\hline $\begin{array}{c}8.468 \\
\text { Anexo } 8\end{array}$ & 08/09/76 & $\begin{array}{l}\text { Dispõe sobre os padrões de emissão para material } \\
\text { particulado a que se refere o Art. } 33-B \text {, acrescentado } \\
\text { pelo Art. } 3^{\circ} \text { do Decreto } n^{\circ} 18.386 \text { de } 22 / 01 / 82\end{array}$ \\
\hline 8.468 & 08/09/76 & $\begin{array}{l}\text { O Art. } 7^{0} \text { do referido decreto classifica os corpos } \\
\text { d'água receptores do território do Estado. }\end{array}$ \\
\hline $\begin{array}{l}8.468 \\
\text { Seção II }\end{array}$ & 08/09/76 & $\begin{array}{l}\text { O Art. } 18 \text { do referido decreto dispõe sobre os } \\
\text { padrões de emissão de efluentes líquidos de } \\
\text { qualquer fonte poluidora. }\end{array}$ \\
\hline $\begin{array}{c}8.468 \\
\text { Título IV }\end{array}$ & 08/09/76 & $\begin{array}{l}\text { Os Art. } 51 ; 52 ; 53 ; 55 ; 56 \text { do referido decreto } \\
\text { dispõem sobre a poluição do solo, disposição final, } \\
\text { acumulação temporária e tratamento de resíduos de } \\
\text { qualquer natureza. }\end{array}$ \\
\hline 10.755 & $22 / 11 / 77$ & $\begin{array}{l}\text { Dispõe sobre o enquadramento dos corpos de água } \\
\text { receptores na classificação prevista no Decreto } n^{\circ} \\
8.468 \text { de } 08 / 09 / 76 \text { e dá providências correlatas }\end{array}$ \\
\hline
\end{tabular}

Fonte: Diplomas Legais Estadual SÃO PAULO, 1976 (a, b, c, d, e, f); SÃO PAULO, 1977.

O detalhamento promovido pelas planilhas representadas pelas tabelas

1 , 3 e 5 foram utilizados na elaboração de um fluxograma (FIG.6), que, esquematicamente, correlaciona, nos processos de monoqueima e de biqueima, as diferentes etapas do processo com as matérias-primas e insumos usados e os resíduos gerados. 


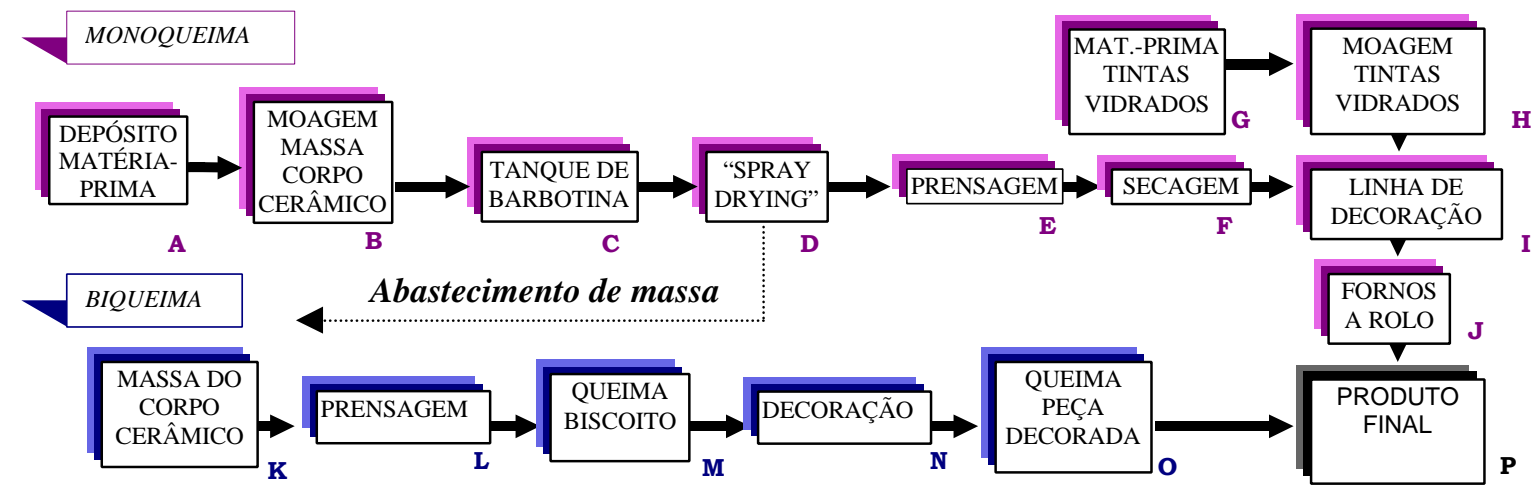

\begin{tabular}{l|l|l}
\hline \multicolumn{1}{c|}{ ETAPAS } & \multicolumn{1}{|c}{ MATERIAS-PRIMAS/INSUMOS } & \multicolumn{1}{c}{ RESÍDUOS GERADOS } \\
\hline A & Argila; Filito; Taguá; Talco; Feldspato & Partículas em Suspensão \\
\hline B & Água; Massa Corpo Cerâmico; Óleo & Efluente Líquido; Sedimentos \\
\hline $\mathbf{C}$ & Água; Massa do Corpo Cerâmico & Resíduo do Peneiramento da Barbotina \\
\hline $\mathbf{D}$ & Gás Natural; Massa Corpo Cerâmico & Partículas em Suspensão; Gases Exaustão \\
\hline $\mathbf{E}$ & Energia; Óleo; Massa Cerâmico Atomizada & Peças cerâmicas; Partículas Suspensão \\
\hline $\mathbf{F}$ & Gás Natural; Massa Cerâmico Atomizada & Partículas em Suspensão; Gases Exaustão \\
\hline $\mathbf{G}$ & Esmaltes; Corantes; Engobe & Partículas em Suspensão \\
\hline $\mathbf{H}$ & Água; Esmalte; Corantes; Engobe; Óleo & Efluente Líquido; Sedimentos \\
\hline $\mathbf{I}$ & Peças cerâmica; Massa Decoração; Água & Efluente Líquido; Sedimentos; Partíc. Suspensão; Peças Cerâmicas \\
\hline $\mathbf{J}$ & Gás Natural; Energia; Peças cerâmicas & Gases de Exaustão \\
\hline $\mathbf{L}$ & Argila; Filito; Taguá; Talco; Feldspato & Partículas em Suspensão \\
\hline $\mathbf{M}$ & Energia; Óleo; Massa Cerâmica Atomizada & Peças Cerâmicas; Partículas Suspensão \\
\hline $\mathbf{N}$ & Gás Natural; Energia; Peças cerâmicas & Gases de Exaustão \\
\hline $\mathbf{O}$ & Água; Esmalte; Corantes: Fritas; Óleo & Efluente Líquido; Sedimentos \\
\hline $\mathbf{P}$ & Gás Natural; Energia; Peças cerâmicas & Gases de Exaustão \\
\hline
\end{tabular}

Figura 6: Fluxograma do processo produtivo - matérias-primas e insumos utilizados e os resíduos gerados

Fonte: FERRARI et al., 1999. 
A reunião e organização destas diferentes informações obtidas não possibilitavam a hierarquização das etapas com relação aos resíduos gerados. Para tanto, foi elaborada Matriz de Avaliação de Impactos Ambientais que, com informações anotadas in loco e a realização de testes de toxicidade aguda com Daphnia similis (Cladocera, Crustacea) nos efluentes líquidos das diferentes etapas de fabricação, foram estabelecidos critérios para promover a classificação de cada etapa de acordo com o grau de contribuição do seu efeito poluidor nos aspectos ambientais do processo produtivo, possibilitando, também, a proposição de ações pontuais, visando minimizar os impactos ambientais negativos, sem alterar significativamente o processo como um todo. A Matriz de Avaliação de Impactos Ambientais foi desenvolvida com a associação da Matriz de Interação de Leopold (TOMMASI, 1994), com a Matriz de Riscos (MOURA, 1998).

\section{III.1.2. Desenvolvimento da Matriz de Avaliação de Impacto}

\section{Ambiental}

A matriz de interação desenvolvida por Leopold é um método simples mas de grande valia para a orientação dos estudos. Esta matriz é montada na forma de uma tabela, sendo que na primeira linha são apresentadas todas as ações que serão desenvolvidas pelo empreendimento e na primeira coluna as características ambientais que poderão ser afetadas. Ela apresenta uma série de aspectos ambientais e suas relações com as ações impactantes de um 
projeto. Estas matrizes foram adaptadas às indústrias cerâmicas enumerando na horizontal os fatores ambientais e na vertical as etapas do processo produtivo.

A Matriz de Riscos sugerida por MOURA (1998) classifica e prioriza os impactos ambientais com a combinação dos dados de freqüência ou probabilidade com os de gravidade ou grau de severidade dos riscos. Os dados obtidos desta matriz são os mais importantes para a avaliação das etapas do processo produtivo, pois é neste momento que são estabelecidos os critérios de gravidade, possibilitando a hierarquização das etapas do processo produtivo, de acordo com seu grau poluidor. Para evitar a definição de critérios rijos em demasia ou, ao contrário, que minimizem um efeito poluidor, utilizaram-se os resultados de testes de toxicidade realizados nos efluentes líquidos de cada etapa, os quais, para este processo produtivo, forneceram parâmetros confiáveis para a avaliação.

As categorias de gravidade (TAB.7) foram definidas levando-se em consideração os resultados dos testes de toxicidade aguda com Daphnia similis (Cladocera, Crustacea), desperdícios de matérias-primas e a geração de resíduos sólidos, observados nas etapas do processo produtivo. Os números atribuídos representam o peso de cada categoria de gravidade e cada nível de freqüência, os quais serão correlacionados na matriz de risco definindo o efeito poluidor das etapas avaliadas (FIG.7). 
Tabela 7: Categorias de Gravidade

\begin{tabular}{c|c|c|l|}
\hline Definição & Categoria & Peso & \multicolumn{1}{|c}{ Descrição } \\
\hline ALTA & I & 4 & $\begin{array}{l}\text { Toxicidade positiva / Desperdício de } \\
\text { matérias-primas }\end{array}$ \\
\hline MÉDIA/ALTA & II & 3 & $\begin{array}{l}\text { Desperdício notável de matéria-prima / } \\
\text { insumos / tóxico eventualmente }\end{array}$ \\
\hline MÉDIA/BAIXA & III & 2 & $\begin{array}{l}\text { Geração moderada de resíduos / } \\
\text { reaproveitamento dos resíduos / toxicidade } \\
\text { negativa d }\end{array}$ \\
\hline BAIXA & IV & 1 & $\begin{array}{l}\text { Geração desprezível de resíduos / } \\
\text { reaproveitamento dos resíduos / toxicidade } \\
\text { negativa }\end{array}$ \\
\hline
\end{tabular}

A freqüência de ocorrência de impactos ambientais negativos (TAB.8) foi determinada pela observação das etapas do processo produtivo.

Tabela 8: Níveis de freqüência ou probabilidade de ocorrência de impactos ambientais negativos.

\begin{tabular}{c|c|c|l}
\hline Definição & Nível & Peso & \multicolumn{1}{c}{ Descrição } \\
\hline FREQÜENTE & A & 5 & $\begin{array}{l}\text { Ocorre permanentemente quando iniciada a } \\
\text { atividade. }\end{array}$ \\
\hline PROVÁVEL & B & 4 & $\begin{array}{l}\text { Irá ocorrer várias vezes no decorrer do } \\
\text { processo. }\end{array}$ \\
\hline OCASIONAL & C & 3 & $\begin{array}{l}\text { Irá ocorrer algumas vezes no decorrer do } \\
\text { processo. }\end{array}$ \\
\hline REMOTA & D & 2 & $\begin{array}{l}\text { Não se espera que ocorra (embora haja } \\
\text { alguma expectativa) ao longo do processo. }\end{array}$ \\
\hline IMPROVÁVEL & E & 1 & $\begin{array}{l}\text { Pode-se assumir que não irá ocorrer durante } \\
\text { o processo. }\end{array}$ \\
\hline
\end{tabular}

Assim, de acordo com MOURA (1998), para cada ponto, foram correlacionados freqüência $x$ gravidade (FIG.7), e o produto indicou uma das quatro classificações de efeitos: 
- Efeito Crítico: igual ou superior a 9 pontos;

- Efeito Significativo: inferior a 9 e superior a 6 pontos;

- Efeito Reduzido: igual ou inferior a 6 e igual ou superior a 4 pontos

- Efeito Marginal: igual ou inferior a 4 pontos

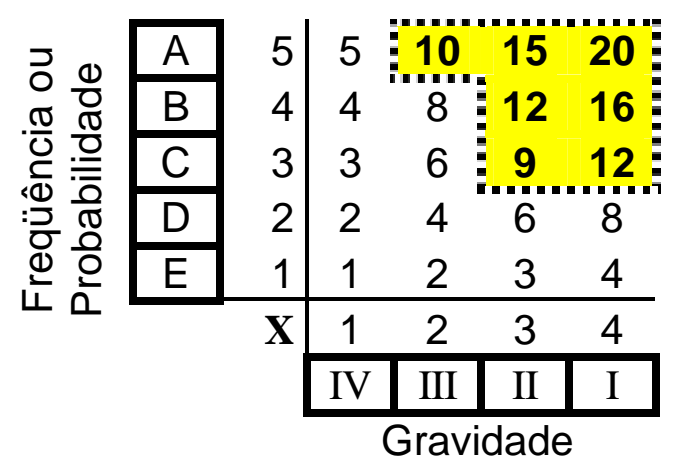

Figura 7: Matriz de Risco

Fonte - (MOURA, 1998)

Em alguns casos encontrava-se, numa única etapa produtiva, mais de um efeito poluidor. Nestes casos, a metodologia utilizada foi a de classificar cada efeito individualmente e a classificação da etapa era a repetição do efeito maior. Desta forma, o fato de apresentar pelo menos um efeito crítico, seja na água, no ar ou no solo, conduziu à mesma classificação para a etapa, mas com a identificação dos efeitos poluidores.

\section{III.1.3. Teste de Toxicidade}

Os testes de toxicidade aguda com Daphnia similis (Cladocera, Crustacea), foram realizados no Centro de Recursos Hídricos da Universidade de São Paulo campus de São Carlos, pela responsável técnica MSc. Clarice 
Maria Rispoli Botta Paschoal e no Departamento de Engenharia Química e Ambiental do IPEN sob a supervisão e orientação das responsáveis técnicas Dra. Mônica Beatriz Mathor e MSc. Silvia Gonçalves Egler. Estes testes visam determinar a relação dose-resposta entre concentração do poluente e comportamento do organismo exposto por 24 ou 48 horas. Com os resultados obtidos determina-se a concentração de poluente que induz a imobilidade de $50 \%$ dos organismos. Os organismos considerados imóveis são aqueles que não são capazes de nadar num intervalo de 15 segundos após a uma agitação suave do tubo. Utilizando-se este sistema diretamente nos pontos de geração dos efluentes líquidos, pode-se prever quais os pontos críticos, antes da emissão. Neste estudo com os efluentes líquidos da indústria de revestimento cerâmico, os testes de toxicidade revelaram os efeitos potenciais dos agentes poluidores do processo industrial.

O teste de toxicidade aguda, efetuado com Daphnia similis com idade entre 6 e 24 horas, é dividido em duas fases, o teste preliminar (FIG.8a) e o teste definitivo (FIG.8b). 


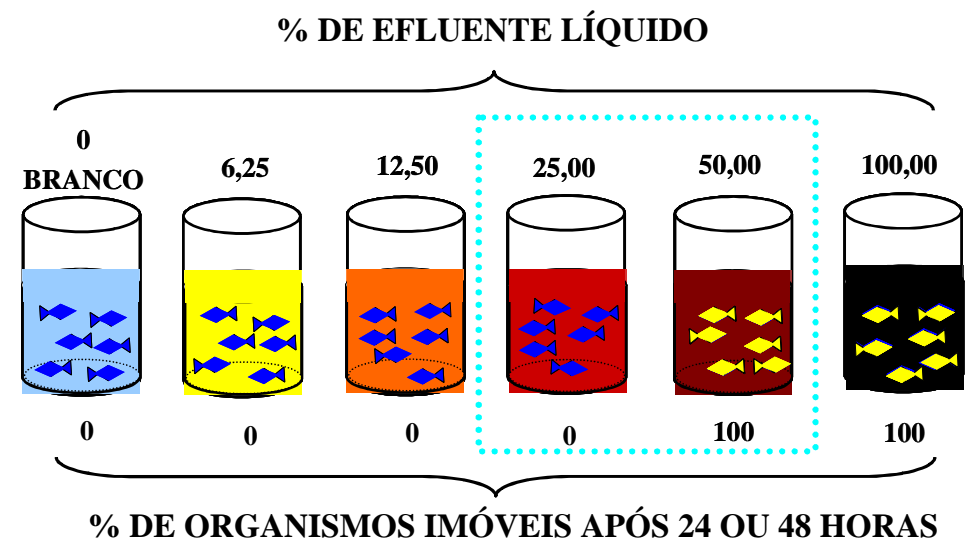

(A)

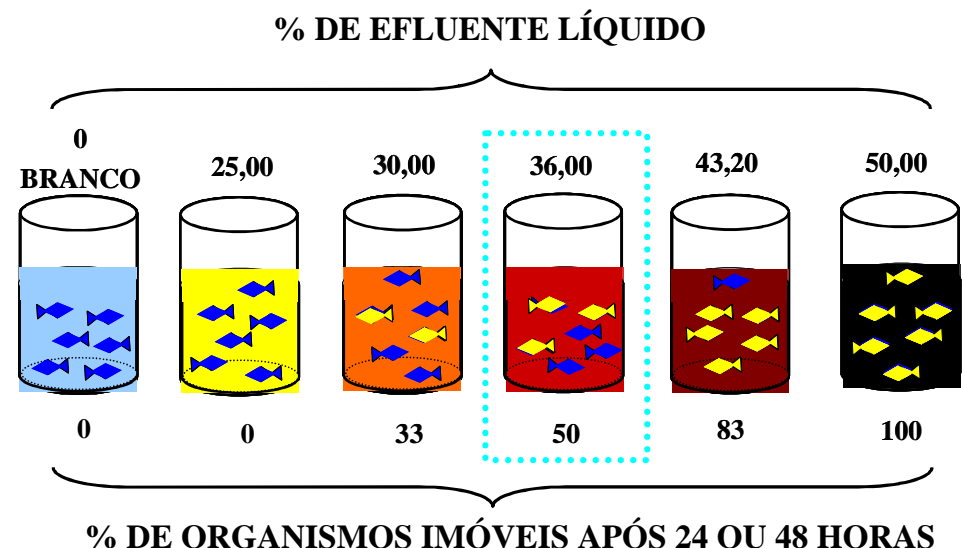

(B)

Figura 8: Exemplo de teste de toxicidade agudo: (A) teste preliminar: identificação do intervalo de concentrações para realização do teste definitivo; (B) teste definitivo: identificação da concentração do efluente que causa a imobilidade de $50 \%$ dos organismos (Concentração Efetiva - CE50\%)

O teste preliminar consiste na exposição dos organismos aquáticos em concentrações variadas do efluente líquido (\% volume). Nesta primeira fase foram preparadas quatro réplicas para cada concentração e, em cada tubo de ensaio foram colocados cinco organismos. Após o período de 12 horas, (em 
ambiente com ausência de luz, à temperatura constante de $20^{\circ} \mathrm{C}$ e sem alimentação) observou-se a quantidade de organismos imóveis em cada tubo. De acordo com o resultado do teste preliminar, foi estabelecido o intervalo de concentrações delimitado pela menor concentração que causa imobilidade a $100 \%$ dos organismos e pela concentração mais elevada na qual não se observa imobilidade dos organismos. Nesta fase definitiva, as observações foram realizadas em dois períodos, após 24 horas e após 48 horas de exposição, sob as mesmas condições citadas acima. Todas as fases do teste de toxicidade foram acompanhadas por um controle (branco), o qual é constituído por quatro réplicas contendo apenas os organismos e a água utilizada no seu cultivo (Apêndice 2) (CETESB, 1997). 


\section{III.2. DIAGNÓSTICO DOS ASPECTOS AMBIENTAIS}

\section{III.2.1. Ensaios Analíticos}

Para a validação da metodologia de avaliação dos impactos ambientais foi realizado um diagnóstico dos aspectos ambientais com a interpretação dos dados analíticos obtidos pelos ensaios realizados em amostras de matériasprimas naturais, sintéticas, resíduos sólidos e efluentes líquidos, do processo de fabricação de placas de revestimentos cerâmicos. Os resultados das análises químicas dos efluentes líquidos foram comparados com os padrões de emissão de efluentes líquidos estipulados pelo decreto $n^{0} 8.468$, Seção II, Art. $18^{\circ}$, de 08 de setembro de 1976 (SÃO PAULO, 1976d).

\section{III.2.1.1. Mapeamento do Processo de Produção}

A partir dos dados obtidos no prognóstico dos aspectos ambientais, foi possível realizar um mapeamento do processo produtivo com a identificação dos pontos de amostragem dos efluentes líquidos e dos resíduos sólidos neles contidos, gerados durante o processo de fabricação de placas de revestimentos cerâmicos (FIG.9). Estes dados também forneceram informações detalhadas das etapas de produção, contribuindo na elaboração de um planejamento de amostragem compatível com a dinâmica deste tipo de indústria. 


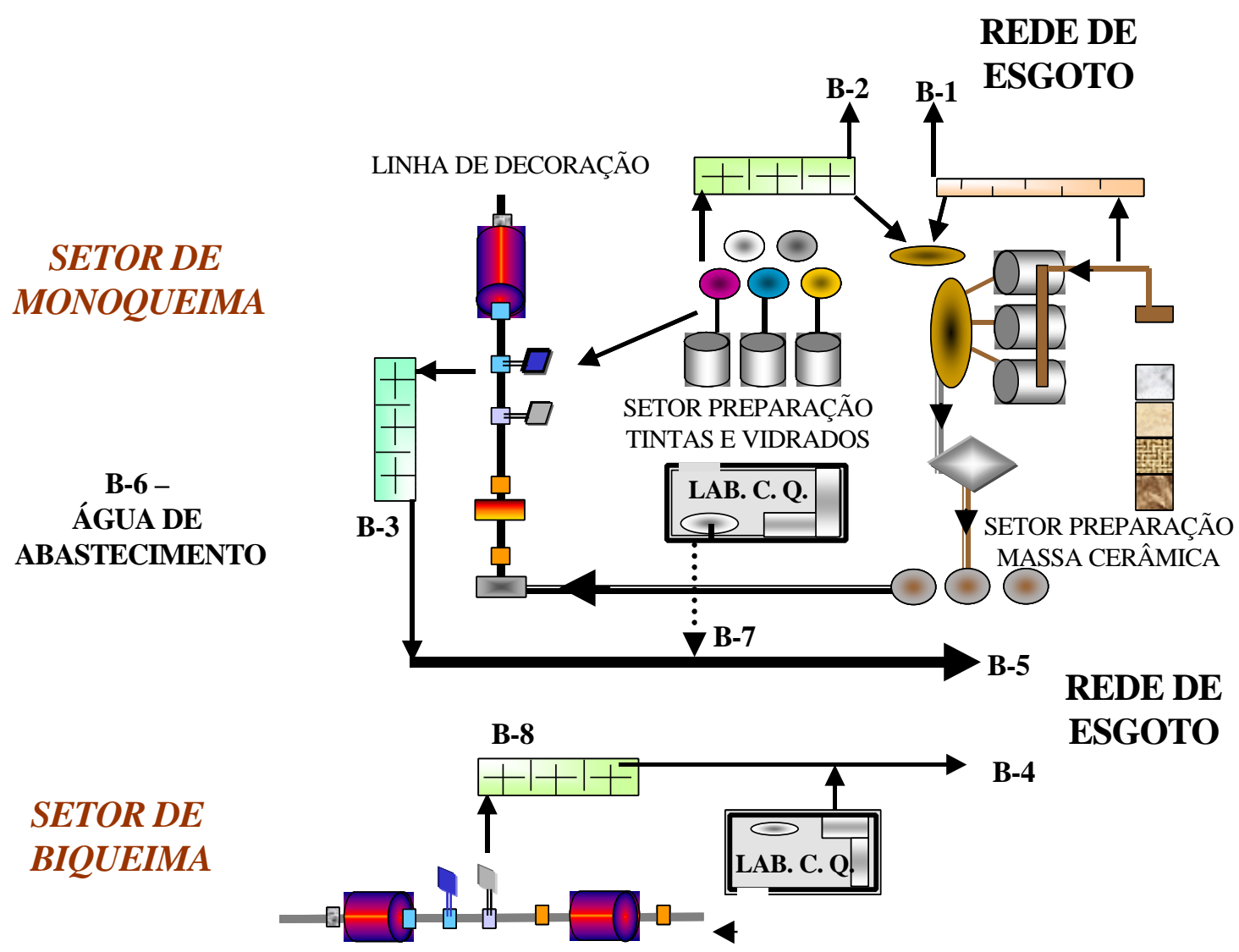

LEGENDA

\begin{tabular}{c|l}
\hline CODIGO & \multicolumn{1}{|c}{ SETOR } \\
\hline B-1 & Efluente líquido do setor de moagem da matéria prima natural; \\
\hline B-2 & Efluente líquido do setor de preparação de tintas e vidrados - PTV; \\
\hline B-3 & Efluente líquido da linha de decoração da monoqueima; \\
\hline B-4 & Efluente líquido total do setor de biqueima; \\
\hline B-5 & $\begin{array}{l}\text { Caixa de coleta dos efluentes líquidos da linha de decoração da } \\
\text { monoqueima e do laboratório de controle de Qualidade }\end{array}$ \\
\hline B-6 & Água de abastecimento; \\
\hline B-7 & Efluente líquido do laboratório de controle de qualidade \\
\hline B-8 & Efluente líquido da linha de decoração do setor de biqueima \\
\hline
\end{tabular}

Figura 9: Localização dos pontos de amostragem do processo de fabricação de revestimentos cerâmicos. Identificação dos pontos de amostragem dos efluentes líquidos 


\section{III.2.1.2. Coleta e Preservação das Amostras}

A confiabilidade e a representatividade de qualquer programa de amostragem dependem, fundamentalmente, da seleção criteriosa dos locais e da utilização correta das metodologias de coleta e preservação de amostras (AGUDO, 1987). Segundo DERISIO (1992), a determinação do número de amostras e da freqüência de amostragem estão diretamente ligados ao objetivo do trabalho de avaliação e estão, normalmente, ligados a alguma ferramenta estatística baseada nas variações de qualidade que ocorrem durante o período de interesse.

A indústria de revestimento cerâmico produz uma grande diversidade de produtos, seja por tamanho, tipo de decoração, processo de queima (monoqueima e biqueima), ou especificidade de uso (revestimentos de pisos, paredes, listelos). O planejamento de produção é definido de acordo com a demanda e é estabelecido mensalmente. Neste período podem ser produzidos diversos produtos com linhas de fabricação independentes e com lotes de peças que requeiram vários dias para completar a metragem solicitada, e também lotes cuja produção começa e termina no mesmo dia. No entanto, todos os resíduos gerados são dispostos num mesmo local, os efluentes líquidos em tanques de decantação e os resíduos sólidos em "boxes" de armazenagem. Desta forma, as coletas foram realizadas em períodos distintos, anotando-se data e hora da coleta, além dos tipos de produtos que estavam sendo produzidos no dia. Estas anotações permitiram identificar a linha que 
estava em produção no período de amostragem e, com os resultados das análises realizadas nas amostras, identificar, das matérias-primas utilizadas, as que produzem resíduos e efluentes líquidos tóxicos.

O uso de modelos estatísticos para determinação do número de amostras mínimo e da freqüência (DERISIO, 1992) dentro do processo produtivo não se justifica, devido à dificuldade de se obter repetitividade nas amostras, visto que dependem dos tipos de produtos que estão em produção.

De acordo com DERISIO (1992) e NUNES (1993), a coleta de amostras é, provavelmente, o passo mais importante para a caracterização de microconstituintes nas águas. É essencial que a amostragem seja realizada com precauções para evitar todas as fontes possíveis de contaminação e perdas.

A descontaminação dos frascos, utilizados para coleta de amostras líquidas para análises de metais, foi realizada pela sua lavagem com detergente neutro diluído (2\%) e enxágüe. Em seguida, lavou-se com ácido nítrico diluído (50\%) e enxaguou-se com água destilada. As tampas e batoques sofreram o mesmo tratamento. $O$ método de preservação das amostras líquidas foi o de adicionar, imediatamente após a coleta, ácido nítrico concentrado até a obtenção de um valor de $\mathrm{pH}<2$. Desta forma garante-se um tempo máximo de 180 dias entre a coleta e a análise. O volume coletado foi de um litro. (AGUDO, 1987; DERISIO, 1992; NUNES, 1993)

A coleta de amostras líquidas para realização dos testes de toxicidade e 
amostragem dos resíduos sólidos e insumos, utilizados na decoração das peças cerâmicas, foi realizada utilizando-se bolsas estéreis de polietileno.

De acordo com a norma técnica CETESB / L5.018 (CETESB, 1997) as amostras destinadas ao teste de toxicidade foram colocadas sob refrigeração a 4ำ, imediatamente após a coleta, proporcionando um tempo máximo de 36 horas entre amostragem e realização do teste. $O$ volume coletado foi de $500 \mathrm{~mL}$. Este volume foi suficiente para a preparação das diluições utilizadas para a realização dos testes.

A metodologia utilizada para a medição de vazão, cronometrar o tempo necessário para completar um recipiente com volume conhecido, sendo que o tempo mínimo recomendável é de 100 segundos, está de acordo com NUNES (1993).

\section{III.2.1.3. Técnicas Analíticas}

Os efluentes líquidos foram caracterizados por testes de toxicidade aguda, cuja metodologia já foi apresentada, e por análises químicas realizadas por espectrometria de absorção atômica. Para os insumos de decoração e resíduos sólidos foram realizadas análises químicas por fluorescência de raio X. Para a caracterização das matérias-primas naturais, que compõem a massa do corpo cerâmico, utilizaram-se as técnicas de difratometria de raio $\mathrm{X}$, análises termodiferencial e termogravimétrica, microscopia eletrônica de varredura e, também, fluorescência de raio $X$. 


\section{- Fluorescência de Raio X}

As análises foram realizadas no Laboratório de Fluorescência de Raio X da divisão de caracterização química do IPEN. As amostras foram preparadas em forma de pastilhas prensadas, que é a forma mais barata e rápida, consistindo basicamente nas seguintes etapas: moagem da amostra para reduzir a variação do tamanho de partícula e posteriormente misturadas com celulose (cera wax), obtendo-se uma diluição de 10\%. Após homogeneização, as amostras foram prensadas formando-se pastilhas e analisadas semiquantitativamente pelo método dos parâmetros fundamentais A preparação e a análise das amostras foram realizadas em conjunto com Wilson Santo Scapin Júnior e Marcos Antonio Scapin, sob a orientação de MSc. Vera Lucia Ribeiro Salvador.

Foram realizadas análises das matérias-primas naturais no Laboratório de Fluorescência de Raio X do Departamento de Engenharia de Minas da Escola Politécnica da USP, utilizando-se o equipamento da marca Philips para análise de argilominerais. As amostras analisadas foram preparadas na forma de pastilhas vitrificadas (pérolas), obtidas pela fusão da amostra.

\section{- Análise Termodiferencial/Termogravimétrica}

A análise foi realizada em aproximadamente $0,2 \mathrm{~g}$ de amostra, num equipamento ATD/TG marca Netzsch modelo STA 409C/7/E, com velocidade de aquecimento de $10^{\circ} \mathrm{C} /$ minuto até a temperatura de $1200^{\circ} \mathrm{C}$ em atmosfera de nitrogênio Super Seco. O equipamento utilizado encontra-se no Laboratório de 
Análises Térmicas do Departamento de Metalurgia do IPEN e as análises realizadas por Yone V. França.

\section{- Microscopia Eletrônica de Varredura}

As imagens das amostras de placas de revestimentos cerâmicos foram obtidas em um sistema combinado de Microscópio Eletrônico de Varredura Phillips XL30 e um microanalisador EDX provido de recursos para processamento e quantificação de imagens. As imagens obtidas foram selecionadas pelo responsável técnico do Laboratório de Microscopia Eletrônica do Departamento de Metalurgia do IPEN, Celso Vieira de Moraes. Foram coletadas imagens de elétrons retroespalhados (BSE) a um potencial de aceleração de $25 \mathrm{KV}$ com ampliações variando de 200X a 800X. A preparação das peças cerâmicas para análise no microscópio eletrônico de varredura foi realizada pelo responsável técnico do Laboratório de Microscopia Óptica do Departamento de Metalurgia do IPEN, Glauson Aparecido F. Machado. As peças foram aparadas em cortador de precisão com disco diamantado; embutidas em resina à base de poliéster; impregnadas a vácuo com resina a base de epoxi; lixadas em lixas de carbeto de silício, grana de 600 mesh; polimento grosso com pasta de diamante de $6 \mu \mathrm{m}$ e $3 \mu \mathrm{m}$ e o polimento fino com pasta de diamante até $1 \mu \mathrm{m}$ (MARIANO et al, 1994; MORAES et al, 1994).

\section{- Difratometria de Raios X}

Utilizou-se um equipamento de difração de raio X marca Siemens, modelo D5000, com capacidade de análises ininterruptas de 40 amostras, acoplado a 
um microcomputador com o software DiffracAT Plus para identificação das fases e tratamento de dados. O equipamento utilizado encontra-se no Laboratório de Difração de Raio X do Instituto de Geociências da USP. As amostras foram preparadas e analisadas sob a orientação do responsável técnico MSc. Flávio M. S. Carvalho. Foram analisadas amostras de massas cerâmicas secas à temperatura de $60^{\circ} \mathrm{C}$ por um período de 24 horas e amostras calcinadas às temperaturas de $900^{\circ} \mathrm{C}$ e $1000^{\circ} \mathrm{C}$, ambas pelos períodos de meia hora e uma hora. Os difratogramas de raio $\mathrm{X}$ foram obtidos com o ângulo inicial de varredura de $3^{\circ} 2 \theta$ e o final de $65^{\circ} 2 \theta$. $O$ ângulo do passo foi de $0.05^{\circ} 2 \theta$ e o tempo de 1 segundo, proporcionando a detecção da maior parte das reflexões dos argilominerais da massa do corpo cerâmico. A fonte de raio X foi CuKalfa, operando a $40 \mathrm{KW}$ e $40 \mu \mathrm{a}$, Gobel Mirror (Marca registrada Siemens/Bruker).

\section{- Espectrometria de Absorção Atômica}

O equipamento utilizado para realizar as análises químicas foi um espectrômetro de absorção atômica, marca Varian, modelo Spectraa 220FS (Fast Sequential). As análises foram efetuadas por Reinaldo Arbue Pini no Laboratório do Gálio do Departamento de Engenharia de Minas da Escola Politécnica da USP. As condições de leitura das amostra/padrão estão apresentadas na tabela 9: 
Tabela 9: Condições de leitura amostra/padrão para as análises químicas por espectrometria de absorção atômica.

\begin{tabular}{|c|c|c|c|}
\hline ELEMENTO & $\begin{array}{c}\text { GASES } \\
\text { UTILIZADOS }\end{array}$ & $\begin{array}{c}\text { CONDIÇÕES } \\
\text { AMOSTRA/PADRÃO }\end{array}$ & $\begin{array}{c}\text { COMPRIMENTO } \\
\text { DE ONDA ( }(\lambda)\end{array}$ \\
\hline $\mathrm{Cu}$ & $\begin{array}{l}\text { Acetileno/óxido } \\
\text { nitroso }\end{array}$ & & 324,8 \\
\hline $\mathrm{Ni}$ & $\begin{array}{l}\text { Acetileno/óxido } \\
\text { nitroso }\end{array}$ & Corretor de background & 232,0 \\
\hline $\mathrm{Cr}$ & $\begin{array}{l}\text { Acetileno/óxido } \\
\text { nitroso }\end{array}$ & & 357,9 \\
\hline Co & $\begin{array}{l}\text { Acetileno/óxido } \\
\text { nitroso }\end{array}$ & & 240,7 \\
\hline V & $\begin{array}{l}\text { Acetileno/óxido } \\
\text { nitroso }\end{array}$ & & 318,5 \\
\hline $\mathrm{Ca}$ & $\begin{array}{l}\text { Acetileno/óxido } \\
\text { nitroso }\end{array}$ & $\begin{array}{|lll|}\text { Adição de } & \mathrm{KCl} \\
\text { amostra/padrão } & \\
\end{array}$ & 422,7 \\
\hline $\mathrm{Pb}$ & Ar/acetileno & & 217,0 \\
\hline $\mathrm{Cd}$ & Ar/acetileno & & 324,8 \\
\hline $\mathrm{Zn}$ & Ar/acetileno & & 213,9 \\
\hline $\mathrm{Ba}$ & $\begin{array}{l}\text { Acetileno/óxido } \\
\text { nitroso }\end{array}$ & \begin{tabular}{|lll} 
Adição de & $\mathrm{KCl}$ \\
amostra/padrão &
\end{tabular} & 553,6 \\
\hline
\end{tabular}

Utilizou-se água destilada como branco e solução de ácido nítrico, 10\% em volume, como solução lavadora do sistema da absorção atômica. As amostras foram lidas diretamente, sem diluição, sendo utilizado padrões compostos de 10ppm de cobre, 10ppm de níquel, 20ppm de crômio, 10ppm de cobalto e 50ppm de vanádio, em ácido nítrico diluído a 10\% em volume e 5ppm de cálcio, 10ppm de chumbo, 3ppm de cádmio em ácido nítrico diluído a 10\% em volume. 


\section{CAPÍTULO IV}

\section{RESULTADOS E DISCUSSÃO}

\section{IV.1. PROGNÓSTICO DOS ASPECTOS AMBIENTAIS}

A Matriz de Avaliação de Impactos Ambientais, resultou na divisão dos dois processos em setores, sendo que 6 localizam-se na produção de peças por monoqueima, com 28 etapas no total e 4 na produção de peças por biqueima, com 13 etapas no total. Estas etapas abrangem as principais atividades que constituem os processos, sendo que cada etapa foi observada separadamente quanto ao desperdício de matérias-primas, e avaliada quanto à sua contribuição poluidora, tendo como base os resultados dos testes de toxicidade aguda apresentados nas tabelas 10 e 11.

Tabela 10: Resultado teste de toxicidade aguda com Daphnia similis - data da coleta 15/12/97.

\begin{tabular}{|c|c|c|c|c|c|c|c|c|}
\hline \multirow{2}{*}{ PARÂMETROS } & \multicolumn{8}{|c|}{ SETORES DE COLETA } \\
\hline & B - 1 & B - 2 & B - 3 & B -4 & B - 5 & B - 6 & B -7 & B - 8 \\
\hline $\mathrm{pH}$ & 8,5 & 7,5 & 7,8 & 7,1 & 8,3 & 7,0 & 7,5 & 7,5 \\
\hline Temperatura & $25^{\circ} \mathrm{C}$ & $25^{\circ} \mathrm{C}$ & $25^{\circ} \mathrm{C}$ & $25^{\circ} \mathrm{C}$ & $25^{\circ} \mathrm{C}$ & $25^{\circ} \mathrm{C}$ & $25^{\circ} \mathrm{C}$ & $25^{\circ} \mathrm{C}$ \\
\hline $\begin{array}{l}\text { Toxicidade } \\
\text { (CE 50\%) }\end{array}$ & n.d & $\begin{array}{l}\text { tóxico } \\
5,20 \% \\
\end{array}$ & n.d. & $\begin{array}{l}\text { tóxico } \\
8,64 \% \\
\end{array}$ & n.d. & n.d & \begin{tabular}{|c|} 
Tóxico \\
$12,90 \%$ \\
\end{tabular} & n.d. \\
\hline
\end{tabular}

n.d. - não detectado 
Tabela 11: Resultado dos testes de toxicidade aguda com Daphnia similis data da coleta 13/04/98.

\begin{tabular}{l|l|l|l|l|l|l|l|l}
\hline \multirow{2}{*}{ PARÂMETROS } & \multicolumn{7}{c}{ SETORES DE COLETA } \\
\cline { 2 - 9 } & $\mathbf{B ~ - 1}$ & $\mathbf{B}-\mathbf{2}$ & $\mathbf{B}-\mathbf{3}$ & $\mathbf{B}-\mathbf{4}$ & $\mathbf{B ~ - 5}$ & $\mathbf{B}-\mathbf{6}$ & $\mathbf{B}-\mathbf{7}$ & $\mathbf{B}-\mathbf{8}$ \\
\hline $\mathrm{pH}$ & 7,4 & 7,3 & 7,4 & 7,2 & 8,0 & 7,0 & 8,0 & 7,5 \\
\hline Temperatura & $25^{\circ} \mathrm{C}$ & $25^{\circ} \mathrm{C}$ & $25^{\circ} \mathrm{C}$ & $25^{\circ} \mathrm{C}$ & $25^{\circ} \mathrm{C}$ & $25^{\circ} \mathrm{C}$ & $25^{\circ} \mathrm{C}$ & $25^{\circ} \mathrm{C}$ \\
\hline $\begin{array}{l}\text { Toxicidade } \\
\text { (CE 50\%) }\end{array}$ & n.d. & $\begin{array}{c}\text { tóxico } \\
18,50 \%\end{array}$ & n.d. & $\begin{array}{c}\text { tóxico } \\
1,20 \%\end{array}$ & n.d. & n.d. & $\begin{array}{l}\text { Tóxico } \\
0,30 \%\end{array}$ & n.d. \\
\hline
\end{tabular}

n.d. - não detectado

As alíquotas de efluente líquido retiradas dos locais de coleta B-2 e B-4, produziram resultados positivos para toxicidade, além de apresentarem sólidos em suspensão, provenientes das massas de decoração dos setores que estes representam. O efluente do laboratório de controle de qualidade (B-7), também apresentou toxicidade positiva. Nos demais setores de coleta de efluente líquido, (B - 1, B - 3, B - 5, B - 6 e B - 8) a característica tóxica não foi detectada. Assim os setores da lavagem dos moinhos de decoração (B-2), o efluente líquido do laboratório de controle de qualidade (B-7) no processo de monoqueima e o efluente líquido do setor de biqueima (B-4) foram considerados críticos. Com os resultados dos testes de toxicidade e as observações do processo produtivo, foi executada a avaliação das condições ambientais da indústria, como demonstrado nas tabelas 12 e 13. 
Tabela 12: Matriz de Avaliação de Impactos Ambientais para Indústria de Revestimento Cerâmico / Processo via úmida - Setor de Monoqueima

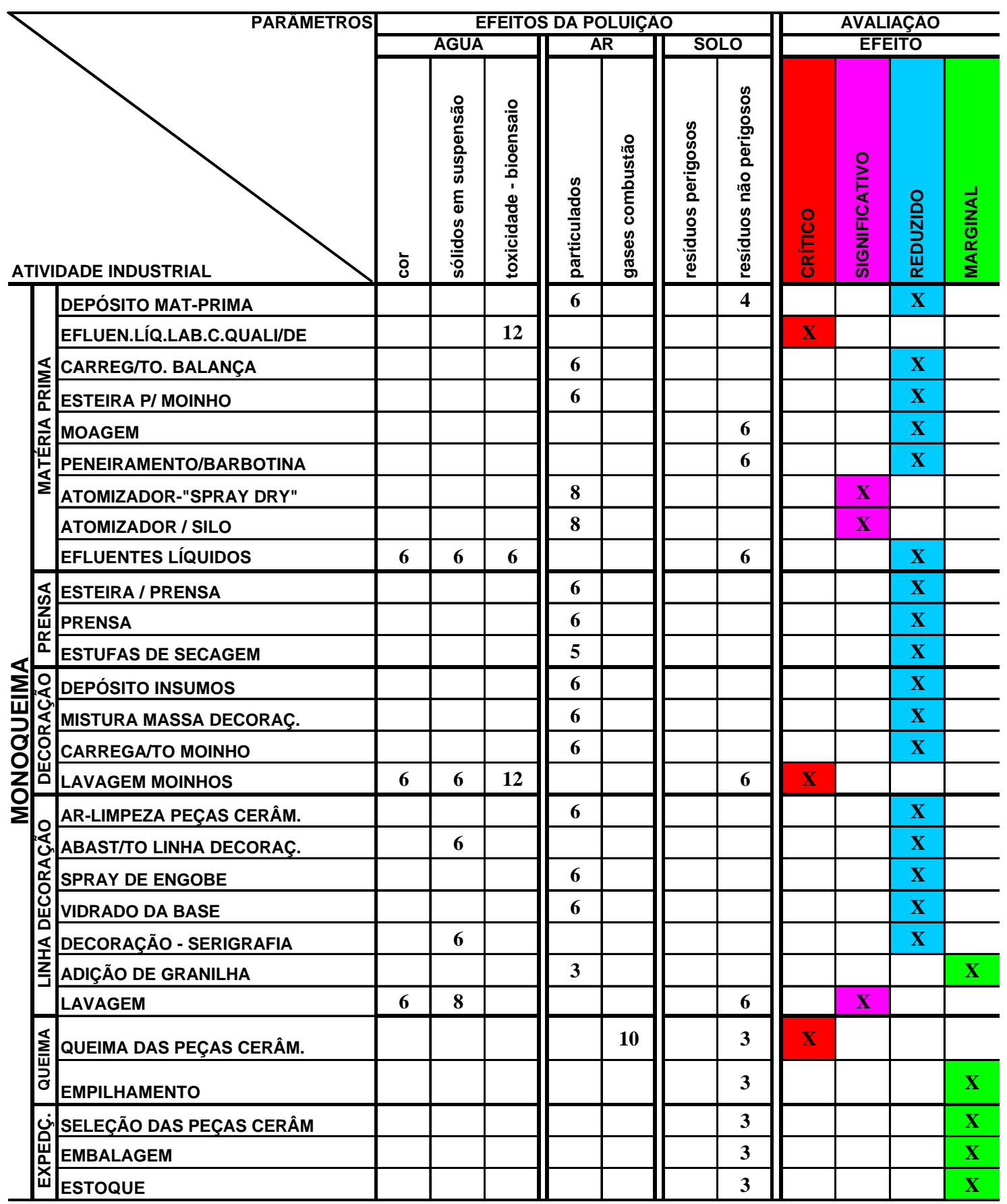


Tabela 13: Matriz de Avaliação de Impactos Ambientais para Indústria de Revestimento Cerâmico / Processo via úmida - Setor de Biqueima.

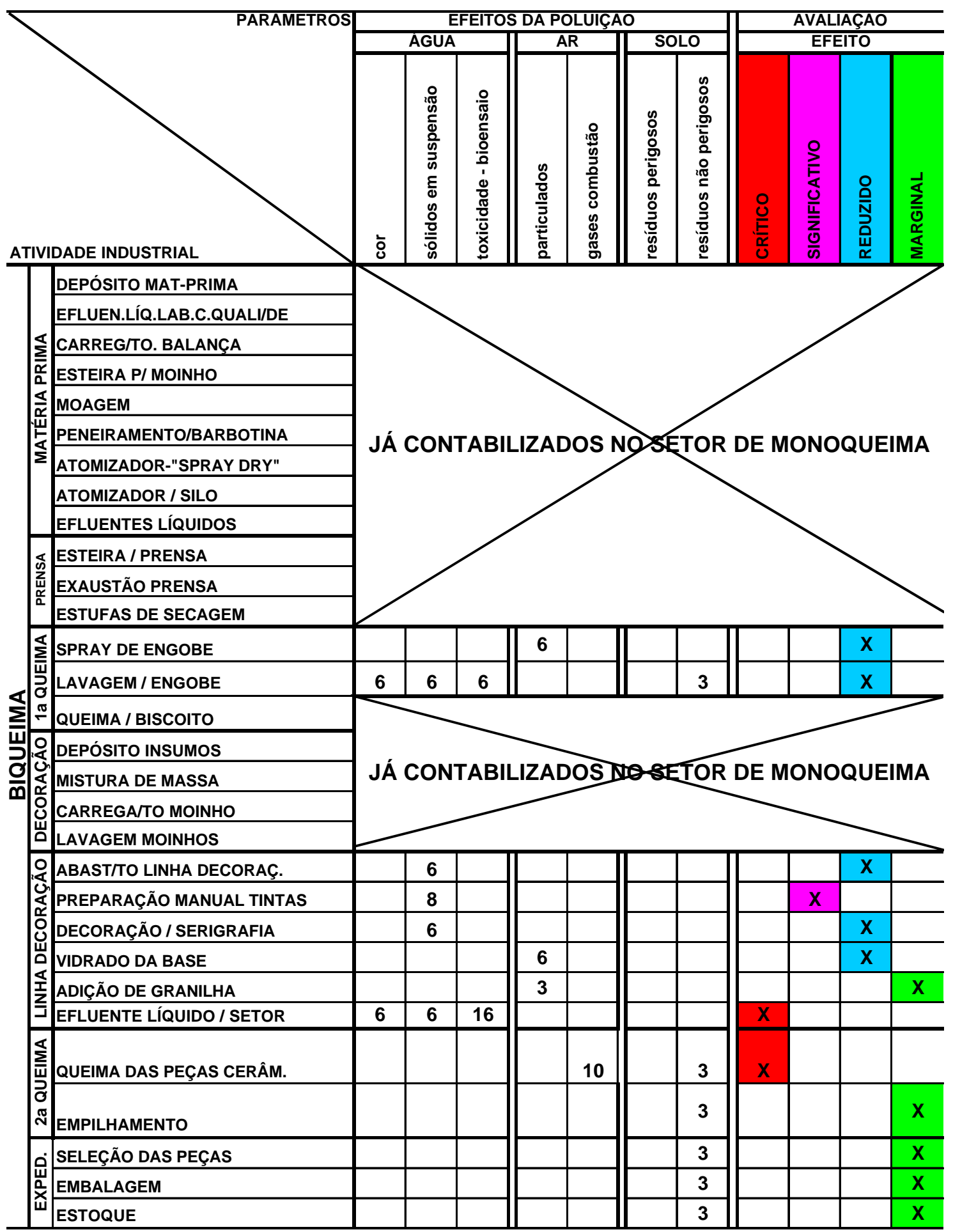


As avaliações dos impactos ambientais, obtidas a partir da metodologia das matrizes, promoveram uma primeira classificação das etapas do processo de fabricação de placas de revestimentos cerâmicos quanto ao seu efeito poluidor (crítico, significativo, reduzido ou marginal), de acordo com as correlações de gravidade (TAB.7) e de freqüência (TAB.8), destacadas com texto em negrito, realizadas em cada etapa do processo produtivo.

\section{a) Com Efeito Crítico}

\section{a.1.) Monoqueima}

- Efluente líquido do laboratório de controle de qualidade - efeito crítico com índice 12 (FIG.7), pois acusou toxicidade positiva (TAB.7) e é irá ocorrer algumas vezes no decorrer do processo (TAB.8).

- Lavagem dos moinhos da preparação da massa de decoração - efeito crítico com índice 12 (FIG.7), devido à toxicidade positiva (TAB.7) e é gerado algumas vezes no decorrer do processo (TAB.8). A esta etapa contabilizam-se, também, a presença de sólidos em suspensão e alterações na cor do efluente devido à presença dos corantes utilizados para decoração das peças, gerando um volume moderado de resíduos, pois parte é reutilizada no processo. A parte que não for reutilizada irá resultar num volume moderado de resíduos não perigosos que serão dispostos, posteriormente, no solo.

- Queima da placas de revestimentos cerâmicos - efeito crítico com índice 10 (FIG.7), resultante dos gases emitidos durante a queima ou sinterização das 
placas de revestimentos cerâmicos, que ocorre permanentemente quando iniciada a produção (TAB.8) com uma geração moderada de resíduos não tóxicos (TAB.7), resultantes das peças cerâmicas que se quebram no decorrer do processo de queima.

\section{a.2.) Biqueima}

- Efluente líquido do setor de biqueima - efeito crítico com índice 16 (FIG.7), devido à toxicidade positiva (TAB.7), além da alteração da cor do efluente líquido devido aos corantes utilizados e geração moderada de sólidos em suspensão, ocorrendo várias vezes no decorrer do processo (TAB.8).

- Queima das placas de revestimentos cerâmicos - efeito crítico com índice 10 (FIG.7), resultante dos gases emitidos durante a queima ou sinterização das placas de revestimentos cerâmicos, e ocorre permanentemente quando iniciada a produção (TAB.8) com uma geração moderada de resíduos não tóxicos (TAB.7), resultantes das peças cerâmicas que se quebram no decorrer do processo de queima.

\section{b) Com Efeito Significativo}

Os efeitos significativos são provocados, principalmente, pela emissão de material particulado, pois as matérias-primas e insumos utilizados estão, em sua maioria, na forma de pó provocando, durante seu manuseio, a suspensão na atmosfera interna da indústria. Em menor número, pela geração moderada de resíduos (TAB.7) provenientes das matérias-primas ou dos sólidos retidos nos tanques de decantação, os quais não foram reaproveitados no processo, 
ou ainda, das peças cerâmicas que se quebram após a sinterização, ocorrendo várias vezes no decorrer do processo (TAB.8).

\section{c) Com Efeito Reduzido}

Este efeito aparece em maior proporção que os demais efeitos identificados, tendo como principais aspectos ambientais os materiais particulados e os resíduos não perigosos, ocorrendo, ocasionalmente (TAB.8), com geração moderada de particulados e/ou resíduos (TAB.7). Este efeito é observado nas etapas: moagem, estufas de secagem, abastecimento de insumos para a linha de decoração e decoração / serigrafia.

\section{d) Com Efeito Marginal}

O efeito marginal é observado numa escala menor que os efeitos reduzidos, estando porém, em segundo lugar. Mesmo ocorrendo algumas vezes no decorrer do processo (TAB.8), a geração de resíduos observada, ou os particulados emitidos, foram considerados desprezíveis (TAB.7) em relação às demais etapas, pois trata-se de locais onde só ocorre o manuseio de peças cerâmicas acabadas.

Conforme ilustrado na figura 10, das 41 etapas observadas, foram identificadas cinco etapas com efeito crítico (12\%), quatro etapas com efeito significativo (10\%), vinte e duas etapas com efeito reduzido $(54 \%)$ e dez com efeito marginal (34\%). 


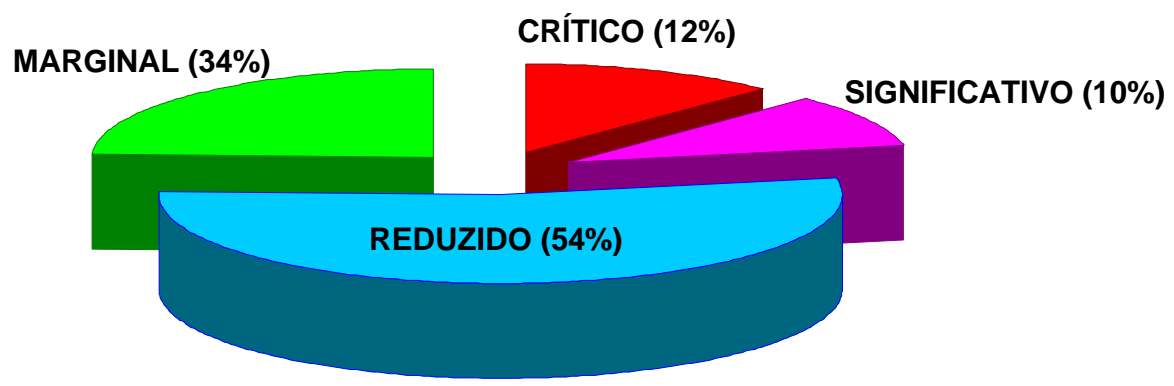

Figura 10: Avaliação das etapas do processo de fabricação de placas de revestimentos cerâmicos pelo método da matriz de avaliação de impactos ambientais

\section{IV.2. DIAGNÓSTICO DOS ASPECTOS AMBIENTAIS}

Com vistas a investigar as principais transformações das peças cerâmicas durante o processo de queima, foi realizada a caracterização química das matérias-primas naturais utilizadas no processo produtivo utilizando-se a técnica de fluorescência de raio $x$, além da combinação das técnicas ATD/TG e DRX em amostras de revestimento cerâmico, antes e após a queima, e a microscopia eletrônica de varredura, em peças queimadas.

\section{IV.2.1. Caracterização das Matérias-Primas Naturais}

Dois tipos de argilas foram utilizadas para a caracterização das matérias-primas naturais, e as massas cerâmicas com elas formuladas. A Argila Cinza Padrão - ACP foi assim denominada devido sua coloração e por já estar sendo utilizada na composição da massa do corpo cerâmico. A Argila 
Azul Teste - AAT, também assim denominada devido sua coloração, a qual estava em fase de teste para incorporação à massa do corpo cerâmico.

A tabela 14 apresenta os dados das análises químicas semiquantitativas para amostras de dois tipos de argila: a argila cinza padrão (ACP) e a argila azul teste (AAT). Verifica-se que, exceto o óxido de titânio, os demais óxidos estudados na argila AAT apresentam valores duas vezes maiores do que os da argila cinza padrão.

Tabela 14: Análise semi-quantitativa, realizada pela técnica analítica fluorescência de raio $\times$ (WDXRF) - método dos parâmetros fundamentais, de alguns óxidos presentes na argila cinza padrão (ACP) e na argila azul teste (AAT). Valores em porcentagem de óxidos.

\begin{tabular}{l|c|c|c|c|c|c}
\hline \multirow{2}{*}{ Amostra } & \multicolumn{7}{|c}{ Análise Química } \\
\cline { 2 - 7 } & $\begin{array}{c}\mathrm{TiO}_{2} \\
(\%)\end{array}$ & $\begin{array}{c}\mathrm{Fe}_{2} \mathrm{O}_{3} \\
(\%)\end{array}$ & $\begin{array}{c}\mathrm{CaO} \\
(\%)\end{array}$ & $\begin{array}{c}\mathrm{MgO} \\
(\%)\end{array}$ & $\begin{array}{c}\mathrm{K}_{2} \mathrm{O} \\
(\%)\end{array}$ & $\begin{array}{c}\mathrm{Na}_{2} \mathbf{O} \\
(\%)\end{array}$ \\
\hline ACP Seca & 6,24 & 6,08 & 0,53 & 0,09 & 3,68 & 0,17 \\
\hline AAT Seca & 3,83 & 11,10 & 0,93 & 0,19 & 6,17 & n.d. \\
\hline
\end{tabular}

Por outro lado, na composição da massa do corpo cerâmico (TAB.15), da qual as argilas fazem parte, esta diferença não interfere na composição final, pois são feitos acertos com outros componentes da formulação da massa cerâmica. 
Tabela 15: Análise química semi-quantitativa das massas cerâmicas usando a argila cinza padrão (ACP) e a argila azul teste (AAT), pela técnica fluorescência de raio $X$, método da pastilha fundida. Valores em porcentagem de óxidos.

\begin{tabular}{l|l|l|l|l|l|l|l|l|l|l}
\hline & \multicolumn{10}{c}{ Análise Química } \\
\cline { 2 - 10 } Amostra & $\begin{array}{l}\mathrm{SiO}_{2} \\
\mathrm{Si} \\
(\%)\end{array}$ & $\begin{array}{l}\mathrm{Al}_{2} \mathbf{O}_{3} \\
\mathbf{A l} \\
(\%)\end{array}$ & $\begin{array}{l}\mathrm{Fe}_{2} \mathbf{O}_{3} \\
\mathbf{F e} \\
(\%)\end{array}$ & $\begin{array}{l}\mathbf{M n O} \\
\mathbf{M n} \\
(\%)\end{array}$ & $\begin{array}{l}\mathbf{M g O} \\
\mathbf{M g} \\
(\%)\end{array}$ & $\begin{array}{l}\mathbf{C a O} \\
\mathbf{C a} \\
(\%)\end{array}$ & $\begin{array}{l}\mathbf{N a}_{2} \mathbf{O} \\
\mathbf{N a} \\
(\%)\end{array}$ & $\begin{array}{l}\mathbf{K}_{2} \mathbf{O} \\
\mathbf{K} \\
(\%)\end{array}$ & $\begin{array}{l}\mathbf{T i O}_{2} \\
\mathbf{T i} \\
(\%)\end{array}$ & $\begin{array}{l}\mathbf{P}_{2} \mathbf{O}_{5} \\
\mathbf{P} \\
(\%)\end{array}$ \\
\hline $\begin{array}{l}\text { Massa } \\
\text { C/ ACP }\end{array}$ & 60,64 & 16,39 & 2,73 & 0,03 & 1,61 & 2,43 & 0,20 & 3,59 & 1,10 & 0,05 \\
\hline $\begin{array}{l}\text { Massa } \\
\text { C/ AAT }\end{array}$ & 61,35 & 16,91 & 2,88 & 0,03 & 1,61 & 2,25 & 0,25 & 3,77 & 1,13 & 0,05 \\
\hline
\end{tabular}

Com as informações obtidas pelos termogramas, pode-se compreender as alterações no corpo cerâmico durante o aquecimento (NORTON, 1973). A água, juntamente com cátions orgânicos, são eliminados com absorção de calor (NORTON, 1973; GRIM, 1953), como pode ser observado nos picos endotérmicos a $108^{\circ} \mathrm{C}, 299^{\circ} \mathrm{C}$ e $547^{\circ} \mathrm{C}$ (FIG.11) e a $126^{\circ} \mathrm{C}$ e $550^{\circ} \mathrm{C}$ (FIG.13), e caracterizada pelas perdas de massa de $4,3 \%$ do início do aquecimento até a temperatura de $108^{\circ} \mathrm{C} ; 2 \%$ entre as temperaturas de $200^{\circ} \mathrm{C}$ e $299^{\circ} \mathrm{C} ; 5,9 \%$ entre as temperaturas de $500^{\circ} \mathrm{C}$ e $547^{\circ} \mathrm{C}$ (FIG.12), pelas perdas de massa de $6,2 \%$ do início do aquecimento até a temperatura de $126^{\circ} \mathrm{C}$ e $4,9 \%$ entre $400^{\circ} \mathrm{C}$ e $549^{\circ} \mathrm{C}$ demonstradas pela figura 14 .

Os hidróxidos que ocorrem nos argilominerais são os seguintes: $\mathrm{AlOOH}$ (diásporo, boemita); $\mathrm{Al}(\mathrm{OH})_{3}$ (gibsita, baierita, nordstrandita, cliaquita-amorfo); $\mathrm{FeOOH}$ (goetita, lepidocrocita); $\mathrm{Ca}(\mathrm{OH})_{2}$ (portlandita); $\mathrm{Mg}(\mathrm{OH})_{2}$ (brucita), (MACKENZIE, 1957; SANTOS, 1975). Estes hidróxidos originam bandas 
endotérmicas muito intensas de desidroxilação, geralmente entre $300^{\circ} \mathrm{C}$ e $550^{\circ} \mathrm{C}$, contribuindo para o aparecimento dos picos endotérmicos da argila ACP nas temperaturas de $299^{\circ} \mathrm{C}$ e de $547^{\circ} \mathrm{C}$ (FIG.11), e a $550^{\circ} \mathrm{C}$ para a argila AAT (FIG.13). Segundo SANTOS (1975), a desidroxilação da cliaquita $\left(\mathrm{Al}(\mathrm{OH})_{3}\right)$ pode originar um pico endotérmico máximo a $285^{\circ} \mathrm{C}$, e o máximo dos picos endotérmicos de desidroxilação do diásporo e da boemita (AIOOH) encontra-se em $550^{\circ} \mathrm{C}$.

Outra característica observada, entre $800^{\circ} \mathrm{C}$ a $1000^{\circ} \mathrm{C}$, tanto para a argila ACP como para a argila AAT (FIG.11, 13), foi a presença de um pico endotérmico pequeno, seguido por um pico exotérmico que representa a nucleação da mulita, caracterizando o comportamento térmico específico de argilas cauliníticas bem cristalizadas.

Nota-se, com a comparação das curvas termodiferenciais, que a formação da mulita para a argila ACP ocorre a $977^{\circ} \mathrm{C}$ (FIG.11) e para a argila AAT ocorre a $919^{\circ} \mathrm{C},(\mathrm{FIG} .13)$. Segundo SANTOS (1975), a presença de teores mais elevados de metais alcalinos e ferro resultam na diminuição da temperatura de formação da mulita. 


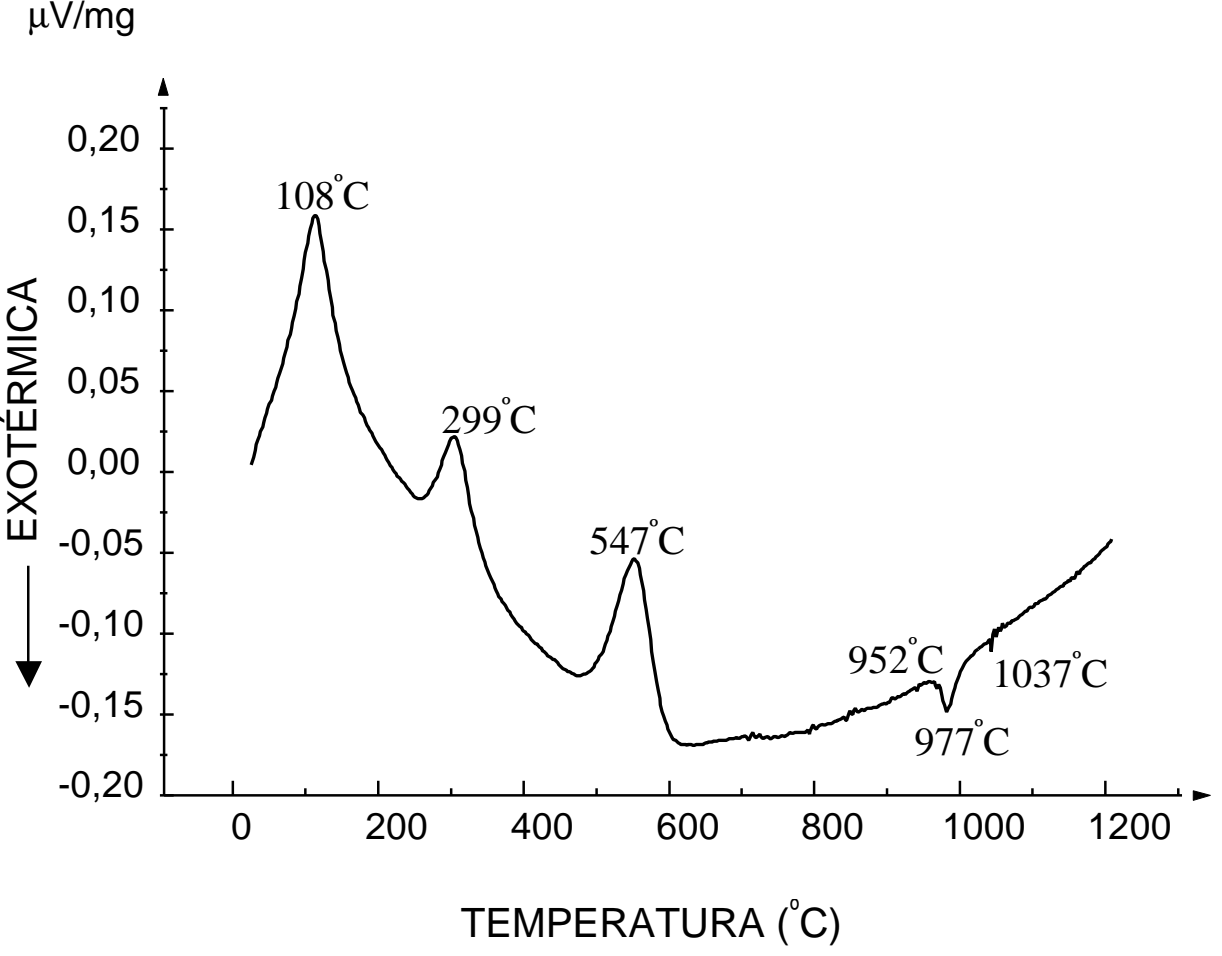

Figura 11: Curva termodiferencial - argila cinza padrão (ACP).

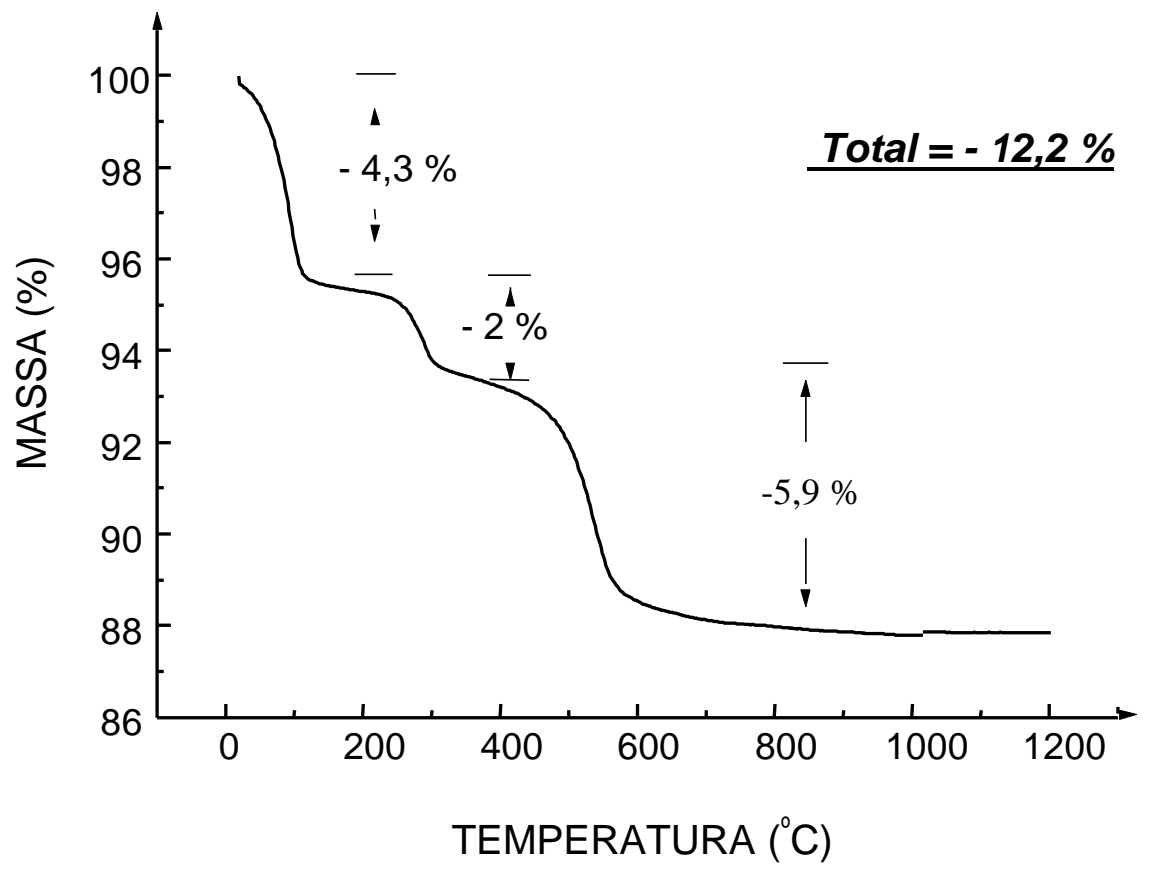

Figura 12: Curva termogravimétrica - argila cinza padrão (ACP). 


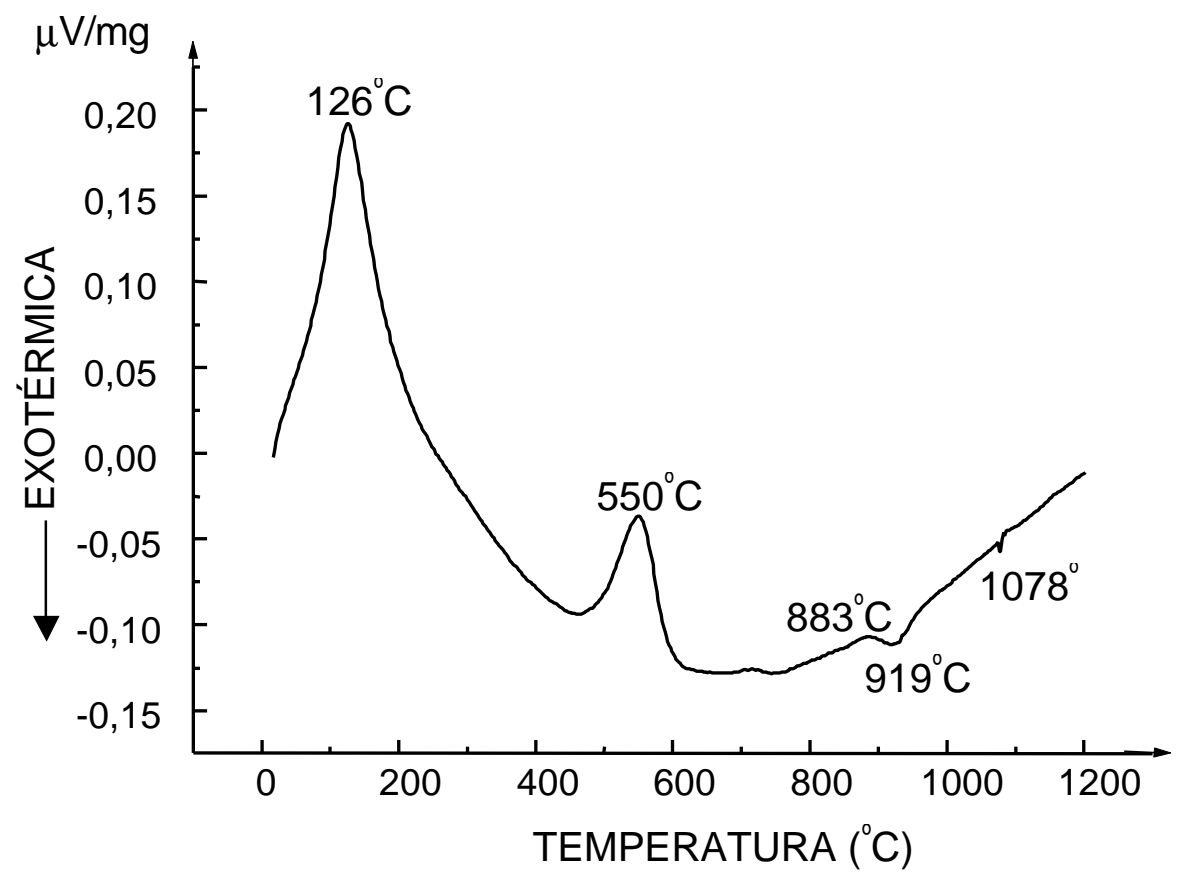

Figura 13: Curva termodiferencial - argila azul teste (AAT).

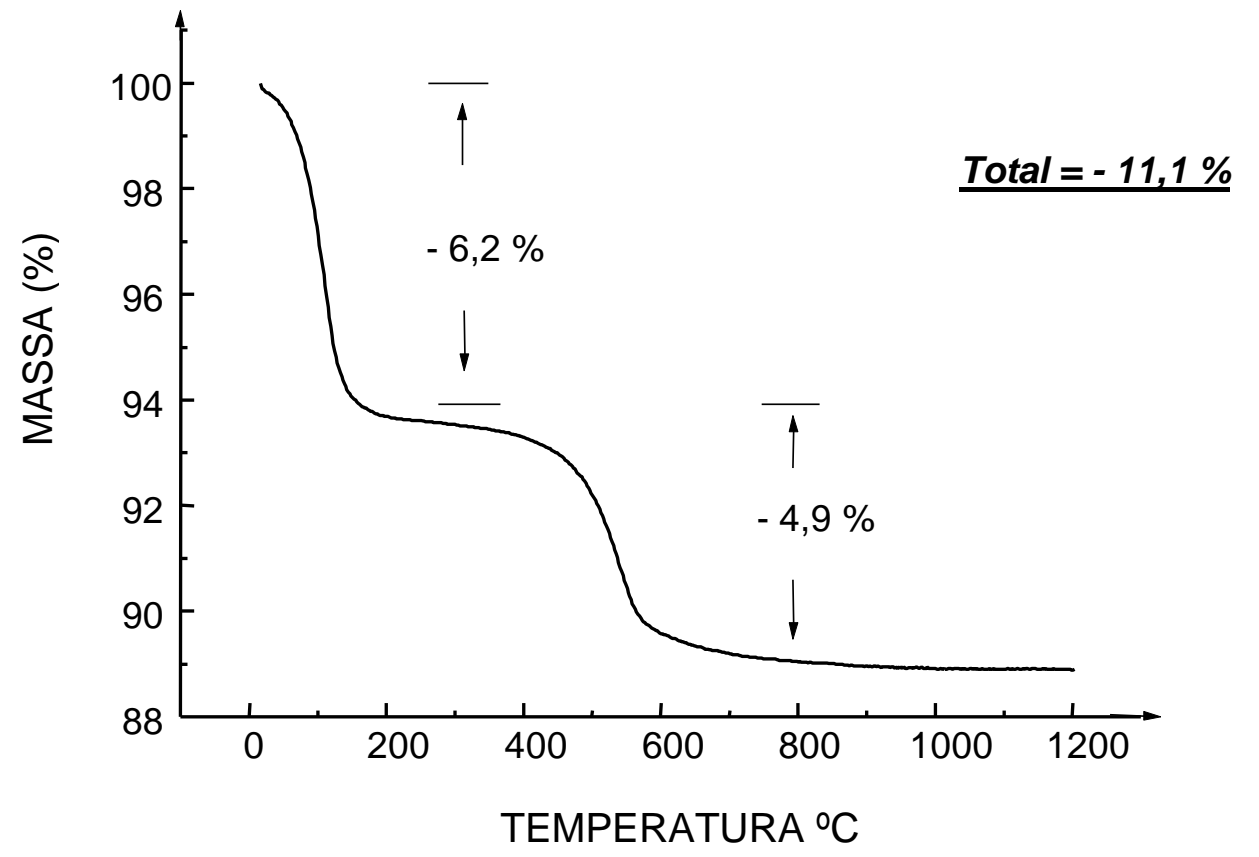

Figura 14: Curva termogravimétrica - Argila Azul Teste (AAT). 
As informações microestruturais obtidas pela microscopia eletrônica de varredura (FIG.15, 16, 17), orientam o desenvolvimento de critérios de preparação das peças cerâmicas, possibilitando a observação mais detalhada dos grãos e a identificação dos materiais vítreos (potencialmente tóxicos ou não). Estas informações também determinam a relação da variação destes parâmetros com a melhoria das qualidades intrínsecas das peças cerâmicas, bem como podem determinar a eficiência de inertização do revestimento cerâmico.

Além das perdas de massa, observadas nas curvas termogravimétricas das figuras 12 e 14 , durante o aquecimento (a partir de $350^{\circ} \mathrm{C}$ até $1150^{\circ} \mathrm{C}$ ) ocorrem também algumas decomposições, tais como as dos carbonatos e sulfatos (SANTOS, 1975), com liberação dos gases $\mathrm{CO}_{2}, \mathrm{SO}_{2}$ e $\mathrm{SO}_{3}$. Estes gases se deslocam à superfície, por forças de tensão superficial, e arrebentam, formando os poros. Se a temperatura máxima de queima ou o tempo de permanência sob esta temperatura forem insuficientes, estes gases são aprisionados na região do esmalte formando bolhas (NORTON, 1973). Estas regiões podem ser observadas por microscopia eletrônica de varredura (MEV), como as imagens obtidas pela análise de corpos de prova de um piso cerâmico (FIG.15) e de um azulejo (FIG.16), onde observam-se bolhas com diâmetros variando entre e $5 \mu \mathrm{m}$ e $50 \mu \mathrm{m}$. 
As regiões demarcadas nestas figuras são, respectivamente:

I. corpo cerâmico - podem apresentar vários componentes como por exemplo, a caulinita, o talco, o filito, o taguá verde e a calcita.

II. engobe - é uma mistura da massa do corpo cerâmico com o vidrado, sua função é a de proporcionar uma melhor aderência entre estas camadas.

III. vidrado ou esmalte - constituído por material vítreo coalescido, cujo objetivo é fornecer uma superfície dura, não-absorvente e de fácil limpeza.

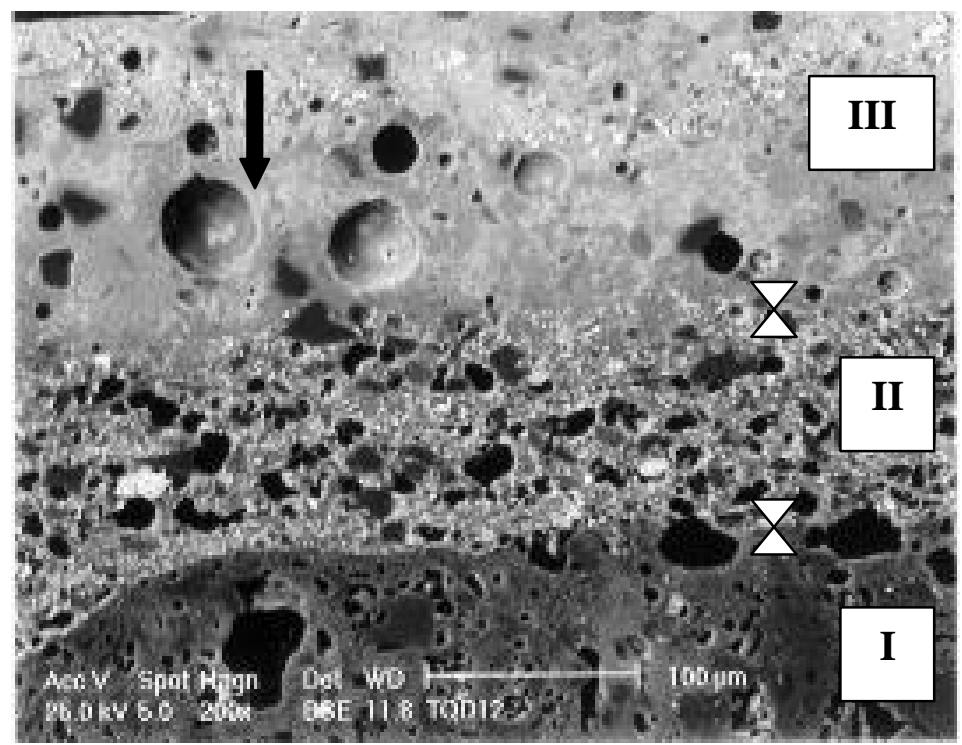

Figura 15: Interface 8 - corpo cerâmico(I) -engobe(II) -esmalte (III) de um piso - setas indicam os poros na camada de esmalte com diâmetros variando entre 5 a $50 \mu \mathrm{m}$. 


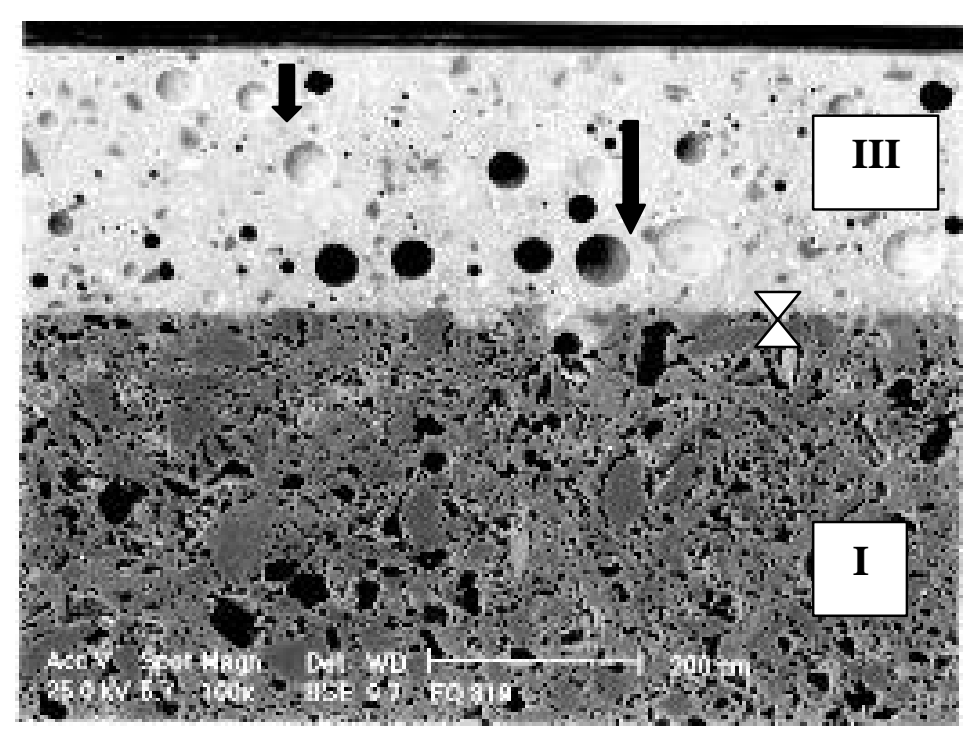

Figura 16: Interface 8 - corpo cerâmico (I) - esmalte de um azulejo (III) - setas indicam os poros na camada do esmalte com diâmetros variando entre 5 a $50 \mu \mathrm{m}$.

Segundo SANTOS (1975), em temperaturas elevadas, ocorrem as transformações nos cristais. Um exemplo deste tipo de transformação pode ser observada com a sílica. Há, pelo menos, seis formas cristalinas de sílica, além da possibilidade de ocorrer a dissolução dos seus grãos, formando uma fase vítrea. A retração de queima da caulinita atinge o valor máximo a cerca de $950^{\circ} \mathrm{C}$; a vitrificação se inicia entre $950^{\circ} \mathrm{C}$ e $1225^{\circ} \mathrm{C}$ devido à liberação de cristobalita $\left(\mathrm{SiO}_{2}\right)$, que irá reagir com óxidos metálicos livres, formando material vítreo. Este fenômeno pode ser observado na figura 17. 


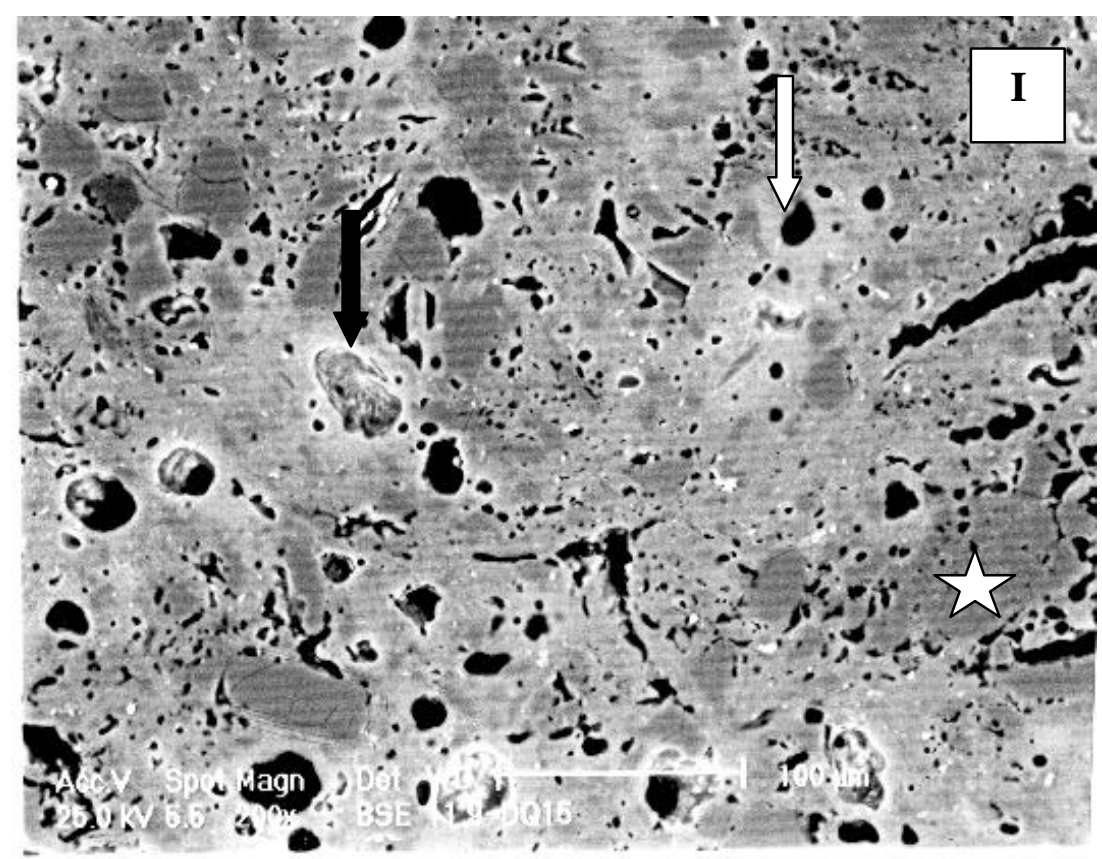

Figura 17: Corpo cerâmico (I) - material vítreo, ação dos cátions modificadores: seta branca - poro; seta preta - grão de calcita; estrela - grãos de quartzo.

As imagens da região do corpo cerâmico (FIG.17) proporcionam a visualização desta fase vítrea formada a partir dos silicatos. As regiões que apresentam cor uniforme (manchas), indicando uma superfície homogênea, caracterizam os arranjos cristalinos que estão fornecendo matéria para a formação da fase vítrea. A sílica passa, gradativamente, da fase cristalina, para a fase vítrea, com nuances cada vez mais claras a partir da região central (fase cristalina). Nota-se a influência do cálcio, em particular, como fornecedor de elementos que facilitam a formação da fase vítrea pela aura mais clara que contorna o grão, possivelmente grão de calcita. 
Com exceção das partículas que se soltaram durante o polimento das amostras, as figuras 15 e 16 evidenciam uma grande quantidade de poros com diâmetros que variam de $50 \mu \mathrm{m}$ a $70 \mu \mathrm{m}$, tanto na região do corpo cerâmico, como também nas regiões do engobe e do esmalte. Observa-se ainda, que na biqueima as bolhas aprisionadas são provenientes da decomposição de compostos existentes no esmalte, constituindo em mais de $20 \%$ da área analisada e que, possivelmente teriam sido eliminadas com um período de queima maior ou uma temperatura mais elevada.

Com auxilio da técnica de difratometria de raio $\mathrm{X}$ é possível constatar as transformações das substâncias cristalinas da massa do corpo cerâmico no processo de queima. A observação dos difratogramas de raio $\mathrm{X}$ das amostras nas diferentes temperaturas de calcinação (FIG.18), permitem observar que a destruição da estrutura cristalina da caulinita e da ilita ocorrem ainda em temperaturas abaixo da temperatura máxima de queima $\left(1175^{\circ} \mathrm{C}\right)$ e que a nucleação da mulita se intensifica após atingida a temperatura de $1000^{\circ} \mathrm{C}$. Observando-se a curva termodiferencial da figura 13, verifica-se que a nucleação da mulita ocorre a $919^{\circ} \mathrm{C}$. A nucleação da mulita também está relacionada com a cristalinidade da caulinita e impurezas. A presença de minerais como o ferro e o titânio, aumenta ou intensifica a formação da mulita. Minerais contendo boro e cálcio atuam da mesma forma, porém em menor intensidade, a relativa influência destes elementos varia de acordo com a temperatura (SANTOS, 1975). 


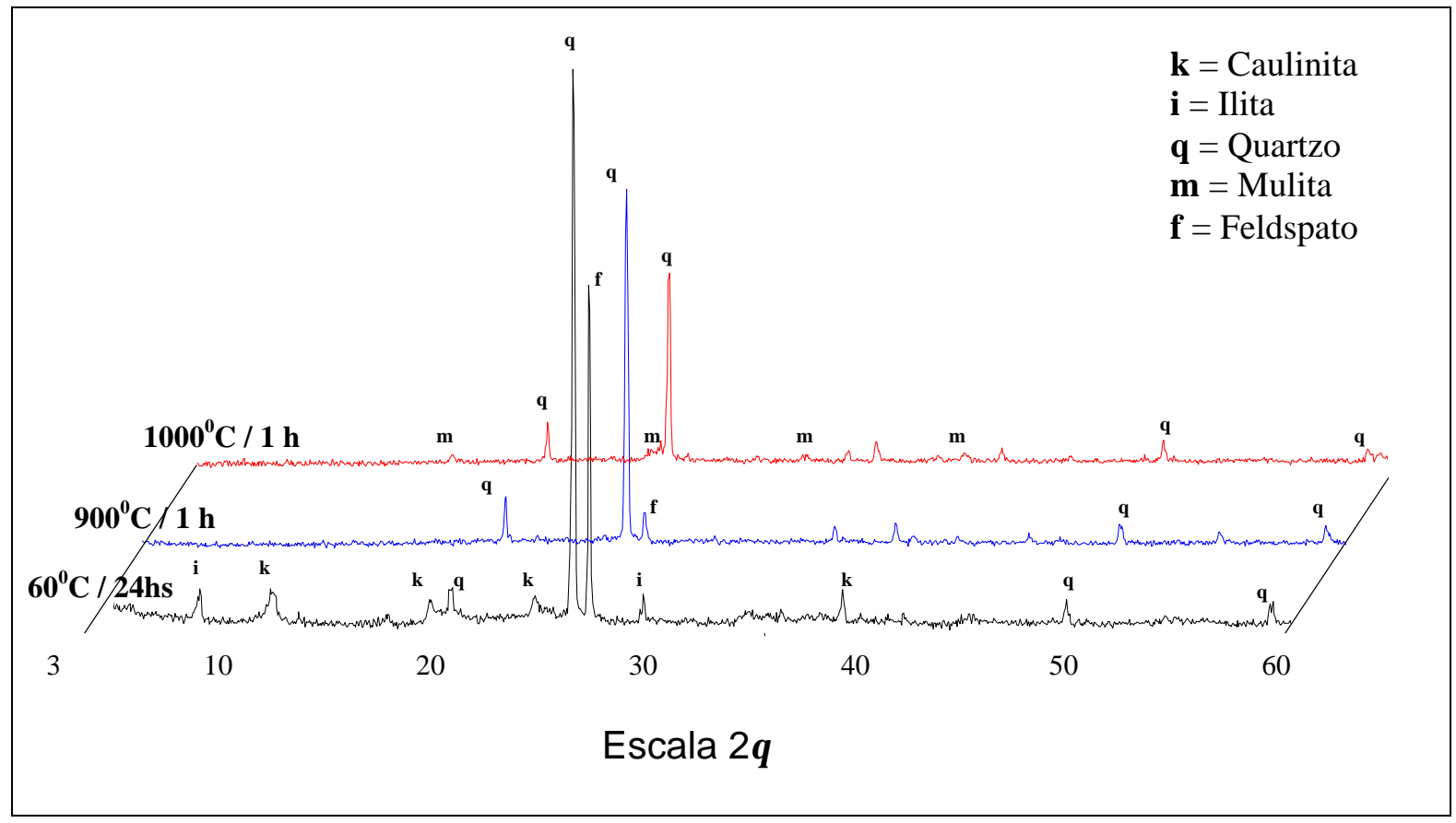

Figura 18: Difratogramas de raio $X$ demonstrando o comportamento térmico da massa de revestimento cerâmico.

Escala $2 \theta$, velocidade $2^{\circ} 2 \theta$ / minuto, iniciando em $3^{\circ} \mathrm{e}$ terminando em $60^{\circ}$, ânodo CuK $\alpha$

A observação conjunta das micrografias e difratogramas de raio $X$ mostra a destruição dos minerais como feldspato, ilita, caulinita e quartzo, contribuindo para a formação da fase vítrea e, a temperatura de $1000^{\circ} \mathrm{C}$, para a nucleação da mulita.

$\mathrm{Na}$ figura 18 , entre as temperaturas de $60^{\circ} \mathrm{C}$ e $1000^{\circ} \mathrm{C}$, verifica-se que $\mathrm{o}$ pico que representa o quartzo vai diminuindo, indicando que a estrutura cristalina está se modificando para a formação da fase vítrea. Este processo é facilitado pela presença dos materiais fundentes (KIRSCH, 1972; NORTON, 1973; SANTOS, 1975), representado pelo pico do feldspato, que a $1000^{\circ} \mathrm{C}$ 
desaparece totalmente, indicando que a esta temperatura os materiais fundentes foram totalmente consumidos.

Estes resultados revelam que a qualidade do produto final dependerá, além de outros fatores, principalmente, da composição da massa do corpo cerâmico e do controle de temperatura e tempo de queima.

\section{IV.2.2. Caracterização das Matérias-Primas Sintéticas, dos Resíduos Sólidos e dos Efluentes Líquidos}

As caracterizações realizadas nas matérias-primas sintéticas, nos resíduos sólidos decantados de cada efluente líquido e nos efluentes líquidos, revelaram os pontos críticos do processo produtivo, além de demonstrarem as possíveis fontes de contaminação com metais tóxicos nos efluentes líquidos.

A tabela 16 apresenta os resultados, obtidos pela técnica analítica fluorescência de raio $x$, de diversas matérias-primas sintéticas usadas na formulação da massa de decoração, utilizadas tanto no setor de monoqueima, como no setor de biqueima. 
Tabela 16: Análise semi-quantitativa, realizada pela técnica analítica fluorescência de raio $\times(\mathrm{WDXRF})$ - método dos parâmetros fundamentais, de alguns insumos de decoração utilizados na monoqueima e na biqueima. Resultados em porcentagem de óxidos. Coleta 15/01/98.

\begin{tabular}{|c|c|c|c|c|c|c|c|}
\hline \multirow[b]{2}{*}{ Óxidos } & \multicolumn{7}{|c|}{ Insumos de decoração } \\
\hline & $\begin{array}{c}\text { Esmalte } \\
\text { semi } \\
\text { opaco } \\
(\%) \\
\end{array}$ & $\begin{array}{l}\text { Esmalte } \\
\text { cinza } \\
\text { escuro } \\
(\%) \\
\end{array}$ & $\begin{array}{c}\text { Esmalte } \\
\text { branco } \\
(\%)\end{array}$ & $\begin{array}{c}\text { Engobe (1) } \\
(\%)\end{array}$ & $\begin{array}{c}\text { Esmalte } \\
\text { branco } \\
\text { biqueima } \\
(\%)\end{array}$ & $\mid \begin{array}{c}\text { Engobe (2) } \\
(\%)\end{array}$ & $\begin{array}{c}\text { Engobe (3) } \\
(\%)\end{array}$ \\
\hline $\mathrm{TiO}_{2}$ & ND & 0,044 & ND & 0,11 & ND & 0,42 & 0,34 \\
\hline $\mathrm{SiO}_{2}$ & 57,6 & 55,2 & 55,2 & 20,5 & 52,5 & 59,2 & 67,5 \\
\hline $\mathrm{Al}_{2} \mathrm{O}_{3}$ & 15,8 & 12,4 & 10,8 & 25,8 & 13,3 & 16,5 & 22,7 \\
\hline $\mathrm{ZrO}_{2}$ & 0,046 & 0,05 & 11,0 & 16,5 & 8,99 & 13,7 & 0,18 \\
\hline $\mathrm{K}_{2} \mathrm{O}$ & 3,98 & 1,03 & 1,88 & ND & 2,46 & ND & 1,70 \\
\hline $\mathrm{Na}_{2} \mathrm{O}$ & 3,29 & 2 , & 2,50 & 1,40 & 2,25 & 1,70 & 1,49 \\
\hline $\mathrm{SO}_{3}$ & 0,05 & 0,06 & DI & NDI & NDI & $\mathrm{NDI}$ & 0,08 \\
\hline $\mathrm{P}_{2} \mathrm{O}_{5}$ & 0,122 & 0,32 & 0,7 & 2,62 & 0,08 & 0,47 & 0,48 \\
\hline $\mathrm{MgO}$ & 0,06 & 0,15 & 0,7 & 19,2 & 0,42 & 0,42 & 0,06 \\
\hline $\mathrm{CaO}$ & 6,02 & 9,45 & 7,69 & 0,81 & 6,82 & 1,62 & 0,15 \\
\hline $\mathrm{NiO}$ & ND & 0,02 & ND & 0,008 & ND & 0,008 & 0,006 \\
\hline $\mathrm{ZnO}$ & 6,25 & 0,14 & 4,12 & 0,007 & 7,30 & 0,2 & 0,007 \\
\hline $\mathrm{PbO}$ & 0,03 & 1,33 & ND & 0,004 & 1,29 & 0,06 & 0,004 \\
\hline $\mathrm{Fe}_{2} \mathrm{O}_{3}$ & 0,27 & 1,96 & 0,24 & 1,39 & 0,18 & 0,52 & 0,53 \\
\hline $\mathrm{Cr}_{2} \mathrm{O}_{3}$ & ND & 1,55 & ND & ND & ND & 0,02 & ND \\
\hline $\mathrm{BaO}$ & 3,89 & ND & ND & ND & 2,30 & ND & ND \\
\hline $\mathrm{MnO}$ & 0,021 & 0,02 & ND & 0,11 & ND & ND & 0,015 \\
\hline SrO & 0,16 & & 015 & & 0,06 & 0,006 & ND \\
\hline $\mathrm{B}_{2} \mathrm{O}_{3}$ & ND & 8,52 & ND & ND & ND & ND & ND \\
\hline P.F. & 2,38 & 5,03 & 4,82 & 11,0 & 1,70 & 1,84 & 4,66 \\
\hline
\end{tabular}

ND - Não determinado $(<0,001 \%)$

$\mathrm{NDI}$ - não determinado por interferência espectral P.F. - perda ao fogo a $900^{\circ} \mathrm{C}$

A tabela 17 apresenta os resultados das análises semi-quantitativas dos resíduos sólidos gerados nos pontos de amostragem. 
Tabela 17: Análise semi-quantitativa, realizada pela técnica analítica fluorescência de raio $\times(\mathrm{WDXRF})$ - método dos parâmetros fundamentais, dos resíduos sólidos decantados dos respectivos efluentes líquidos. Resultados em porcentagem de óxidos. Coleta 15/01/98.

\begin{tabular}{|c|c|c|c|c|c|}
\hline \multirow{2}{*}{ Óxidos } & \multicolumn{5}{|c|}{ Pontos de Amostragem - Resíduos Sólidos } \\
\hline & B-1 (\%) & B-2 (\%) & B-3 (\%) & B-4 (\%) & B-5 (\%) \\
\hline$\overline{\mathrm{TiO}_{2}}$ & 0,974 & 0,10 & 0,43 & 0,97 & 0,09 \\
\hline $\mathrm{SiO}_{2}$ & 66,7 & 56,2 & 51,3 & 71,7 & 54,5 \\
\hline $\mathrm{Al}_{2} \mathrm{O}_{3}$ & 16,0 & 14,1 & 17,5 & 13,9 & 13,8 \\
\hline $\mathrm{ZrO}_{2}$ & 0,10 & 11,3 & 8,81 & 0,56 & 2,45 \\
\hline $\mathrm{K}_{2} \mathrm{O}$ & 3,5 & 1,85 & 1,59 & 3,53 & 1,35 \\
\hline $\mathrm{Na}_{2} \mathrm{O}$ & 0,09 & 1,49 & 0,60 & 0,26 & 1,79 \\
\hline $\mathrm{SO}_{3}$ & 0,07 & NDI & NDI & NDI & ND \\
\hline $\mathrm{P}_{2} \mathrm{O}_{5}$ & 0,04 & 0,16 & 0,64 & 0,054 & 0,27 \\
\hline $\mathrm{MgO}$ & 1,91 & 0,23 & 0,36 & 1,18 & 0,22 \\
\hline $\mathrm{CaO}$ & 0,24 & 4,96 & 1,48 & 1,33 & 2,19 \\
\hline $\mathrm{NiO}$ & $\mathrm{ND}$ & 0,017 & $\mathrm{ND}$ & 0,12 & 0,043 \\
\hline $\mathrm{ZnO}$ & 0,09 & 2,31 & 0,92 & 0,024 & 0,81 \\
\hline $\mathrm{PbO}$ & 0,012 & 0,22 & 0,077 & $\mathrm{ND}$ & 0,74 \\
\hline $\mathrm{Fe}_{2} \mathrm{O}_{3}$ & 2,11 & 0,924 & 0,93 & 2,32 & 2,36 \\
\hline $\mathrm{Cr}_{2} \mathrm{O}_{3}$ & 0,026 & 0,22 & 0,013 & 0,47 & 1,85 \\
\hline $\mathrm{BaO}$ & ND & ND & ND & ND & ND \\
\hline $\mathrm{MnO}$ & ND & 0,10 & ND & ND & 0,073 \\
\hline SrO & 0,006 & 0,017 & 0,01 & 0,007 & 0,02 \\
\hline $\mathrm{B}_{2} \mathrm{O}_{3}$ & $\mathrm{ND}$ & $\mathrm{ND}$ & ND & $\mathrm{ND}$ & 8,41 \\
\hline P.F. & 8,0 & 5,40 & 14,9 & 4,0 & 9,0 \\
\hline
\end{tabular}

ND - Não determinado $(<0,001 \%)$

$\mathrm{NDI}$ - não determinado por interferência espectral

P.F. - perda ao fogo a $900^{\circ} \mathrm{C}$

A tabela 18 compara os resultados das análises semi-quantitativas, obtidos na massa de decoração do setor de monoqueima, nos resíduos do tanque de decantação da preparação de tintas e vidrados e na massa de decoração do setor de biqueima. 
Tabela 18: Análise semi-quantitativa, realizada pela técnica analítica fluorescência de raio $x(\mathrm{WDXRF})$ - método dos parâmetros fundamentais, em alguns insumos de decoração da monoqueima e da biqueima e do resíduo sólido do tanque de decantação da etapa de preparação de tintas e vidrados da monoqueima. Resultados em porcentagem de óxidos. Coleta 24/08/99.

\begin{tabular}{|c|c|c|c|}
\hline Óxidos & $\begin{array}{c}\text { Massa de decoração } \\
\text { monoqueima } \\
(\%)\end{array}$ & $\begin{array}{l}\text { Resíduo do tanque de decantação da } \\
\text { etapa de preparação de tintas e } \\
\text { vidrados monoqueima (\%) }\end{array}$ & $\begin{array}{c}\text { Massa de } \\
\text { decoração } \\
\text { biqueima (\%) }\end{array}$ \\
\hline $\mathrm{Na}_{2} \mathrm{O}$ & ND & 2,85 & ND \\
\hline $\mathrm{MgO}$ & 0,26 & 1,08 & ND \\
\hline $\mathrm{Al}_{2} \mathrm{O}_{3}$ & 9,17 & 15,4 & 0,78 \\
\hline $\mathrm{SiO}_{2}$ & 58,0 & 56,2 & 4,8 \\
\hline $\mathrm{P}_{2} \mathrm{O}_{5}$ & 0,06 & ND & ND \\
\hline $\mathrm{SO}_{3}$ & 0,06 & ND & ND \\
\hline $\mathrm{Cl}$ & 0,10 & ND & ND \\
\hline $\mathrm{K}_{2} \mathrm{O}$ & 4,34 & 2,18 & ND \\
\hline $\mathrm{CaO}$ & 10,6 & 6,29 & 0,36 \\
\hline $\mathrm{TiO}_{2}$ & 1,46 & 0,36 & 0,07 \\
\hline $\mathrm{Cr}_{2} \mathrm{O}_{3}$ & 0,35 & 0,13 & 0,83 \\
\hline $\mathrm{Fe}_{2} \mathrm{O}_{3}$ & 0,61 & 0,95 & 0,87 \\
\hline $\mathrm{CoO}$ & ND & 0,03 & 14,0 \\
\hline $\mathrm{ZnO}$ & 9,83 & 2,55 & 16,9 \\
\hline $\mathrm{Rb}_{2} \mathrm{O}$ & 0,02 & ND & ND \\
\hline $\mathrm{SrO}$ & 0,07 & ND & ND \\
\hline $\mathrm{ZrO}_{2}$ & 1,58 & 9,44 & 0,19 \\
\hline $\mathrm{BaO}$ & 3,11 & 0,39 & ND \\
\hline $\mathrm{Pr}_{2} \mathrm{O}_{3}$ & 0,11 & ND & ND \\
\hline $\mathrm{HfO}_{2}$ & 0,08 & ND & ND \\
\hline $\mathrm{CdO}$ & ND & ND & 0,21 \\
\hline $\mathrm{PbO}$ & 0,13 & 0,60 & 40,6 \\
\hline
\end{tabular}

ND - Não determinado $(<0,01 \%)$

As análises, por fluorescência de raio $X$, na massa de decoração do corpo cerâmico, tanto a utilizada no setor de monoqueima como a do setor de biqueima, demonstram que este material apresenta composição química 
bastante variada. Nota-se que a composição da massa de decoração da biqueima é, principalmente, composta por óxido de chumbo (40,6\%), óxido de zinco $(16,9 \%)$ e óxido de cobalto (14\%). Diferentemente, a massa de decoração da monoqueima analisada, é principalmente composta de óxido de silício, óxido de cálcio, óxido de zinco, óxido de alumínio, óxido de potássio e óxido de bário. Esta massa é apenas um dos componentes utilizados no processo de decoração, ficando evidente que, nesta etapa, a probabilidade de se gerar resíduos tóxicos é muito elevada. O custo destes insumos também são os mais elevados dentro desta indústria. Avaliando estes dois fatores, fica clara a importância desta etapa na tomada de medidas que diminuam as perdas.

Simultaneamente às análises químicas dos efluentes líquidos, foram realizados testes de toxicidade aguda onde verifica-se oscilação dos resultados positivos (TAB.19, 20, 21). Como apresentado anteriormente, o grau de toxicidade do efluente é obtido pela análise do comportamento dos organismos-teste, expostos às várias concentrações do teste definitivo. É definida então, a concentração efetiva (CE 50\%), ou seja, a concentração nominal do agente tóxico que causa, letalidade ou imobilidade (efeito agudo) de $50 \%$ dos organismos-teste. A toxicidade do efluente será maior quanto menor for a concentração necessária para observar o efeito agudo (BASSOI et al, 1990; CETESB, 1997). 
Tabela 19: Resultado dos testes de toxicidade aguda com Daphnia similis data da coleta 24/09/99.

\begin{tabular}{|c|c|c|c|c|c|c|c|c|}
\hline \multirow{2}{*}{ PARÂMETROS } & \multicolumn{8}{|c|}{ SETORES DE COLETA } \\
\hline & $\mathrm{B}-1$ & B-2 & B -3 & $\overline{B-4}$ & $\overline{B-5}$ & B - 6 & B -7 & B - 8 \\
\hline $\mathrm{pH}$ & 8,71 & 7,6 & 9,13 & 7,45 & 8,66 & 7,36 & 9,1 & 7,29 \\
\hline Temperatura & $20,2^{\circ} \mathrm{C}$ & $12,3^{\circ} \mathrm{C}$ & $17,8^{\circ} \mathrm{C}$ & $17,5^{\circ} \mathrm{C}$ & $17,2^{\circ} \mathrm{C}$ & $25,2^{\circ} \mathrm{C}$ & $18,7^{\circ} \mathrm{C}$ & $16,1^{\circ} \mathrm{C}$ \\
\hline $\begin{array}{l}\text { Toxicidade } \\
\text { (CE 50\%) }\end{array}$ & $\begin{array}{c}\text { Tóxico } \\
5 \%\end{array}$ & n.d & n.d & $\begin{array}{l}\text { Tóxico } \\
0,28 \%\end{array}$ & n.d. & $\begin{array}{c}\text { Não } \\
\text { tóxico } \\
90 \%\end{array}$ & $\begin{array}{c}\text { Não } \\
\text { tóxico } \\
80 \%\end{array}$ & n.d. \\
\hline
\end{tabular}

n.d. - não detectado

Tabela 20: Resultado dos testes de toxicidade aguda com Daphnia similis data da coleta 26/10/99.

\begin{tabular}{|c|c|c|c|c|c|c|c|c|}
\hline \multirow{2}{*}{ PARÂMETROS } & \multicolumn{8}{|c|}{ SETORES DE COLETA } \\
\hline & B-1 & B - 2 & B - - 3 & B -4 & B-5 & B - 6 & B - 7 & B - 8 \\
\hline $\mathrm{pH}$ & 7,4 & 7,3 & 7,4 & 7,2 & 8,0 & 7,0 & 8,0 & 7,5 \\
\hline Temperatura & $25^{\circ} \mathrm{C}$ & $25^{\circ} \mathrm{C}$ & $25^{\circ} \mathrm{C}$ & $25^{\circ} \mathrm{C}$ & $25^{\circ} \mathrm{C}$ & $25^{\circ} \mathrm{C}$ & $25^{\circ} \mathrm{C}$ & $25^{\circ} \mathrm{C}$ \\
\hline $\begin{array}{l}\text { Toxicidade } \\
\text { (CE 50\%) }\end{array}$ & n.d. & n.d. & n.d. & $\begin{array}{c}\text { Tóxico } \\
0,3 \%\end{array}$ & n.d. & $\begin{array}{c}\text { Não } \\
\text { tóxico } \\
70 \%\end{array}$ & $\begin{array}{c}\text { Tóxico } \\
10 \%\end{array}$ & $\begin{array}{c}\text { Tóxico } \\
50 \%\end{array}$ \\
\hline
\end{tabular}

n.d. - não detectado

Tabela 21: Resultado dos testes de toxicidade aguda com Daphnia similis data da coleta 23/11/99.

\begin{tabular}{l|c|c|c|c|c|c|c|c}
\hline \multirow{2}{*}{ PARÂMETROS } & \multicolumn{7}{|c}{ SETORES DE COLETA } \\
\cline { 2 - 10 } & $\mathbf{B}-\mathbf{1}$ & $\mathbf{B}-\mathbf{2}$ & $\mathbf{B}-\mathbf{3}$ & $\mathbf{B}-\mathbf{4}$ & $\mathbf{B}-\mathbf{5}$ & $\mathbf{B}-\mathbf{6}$ & $\mathbf{B}-\mathbf{7}$ & $\mathbf{B}-\mathbf{8}$ \\
\hline $\mathrm{pH}$ & 9,66 & 9,07 & 9,48 & 7,81 & 8,70 & 7,06 & 9,52 & 8,13 \\
\hline Temperatura & $24,6^{\circ} \mathrm{C}$ & $20,8^{\circ} \mathrm{C}$ & $9,48^{\circ} \mathrm{C}$ & $23^{\circ} \mathrm{C}$ & $21,3^{\circ} \mathrm{C}$ & $24,1^{\circ} \mathrm{C}$ & $21^{\circ} \mathrm{C}$ & $19,1^{\circ} \mathrm{C}$ \\
\hline $\begin{array}{l}\text { Toxicidade } \\
\text { (CE 50\%) }\end{array}$ & n.d. & n.d. & n.d. & $\begin{array}{c}\text { Tóxico } \\
3,5 \%\end{array}$ & n.d. & $\begin{array}{c}\text { Tóxico } \\
30 \%\end{array}$ & n.d. & n.d. \\
\hline
\end{tabular}

n.d. - não detectado

O ponto B-1 (efluente líquido da seção de moagem de matérias-primas naturais, FIG.9), apresentou oscilações quanto à toxicidade positiva (TAB.19, 20, 21). As análises químicas realizadas (TAB.22) (FIG.19) revelaram altas 
concentrações de cálcio, provavelmente proveniente da calcita utilizada na formulação da massa do corpo cerâmico. O cálcio provavelmente aumenta 0 teor de dureza da água, acarretando resultados positivos para o teste de toxicidade. Problemas com o bombeamento da barbotina para o atomizador contaminaram este efluente com óleo, também contribuindo para o resultado positivo para toxicidade.

Tabela 22: Comparação das análises químicas realizadas por espectrometria de absorção atômica no efluente líquido do Ponto B-1 (efluente da seção de moagem). Amostras coletadas em diferentes dias. Valores expressos em mg. $\mathrm{L}^{-1}$

\begin{tabular}{l|r|r|r|r|r}
\hline \multicolumn{1}{c|}{ Metais } & \multicolumn{1}{|c|}{$\mathbf{2 4 / 0 8 / 9 9}$} & \multicolumn{1}{|c|}{$\mathbf{2 4 / 0 9 / 9 9}$} & $\mathbf{2 6 / 1 0 / 9 9}$ & 23/11/99 & \multicolumn{1}{c}{ Art. 18 } \\
\hline $\mathrm{Cd}$ & 0,01 & 0,02 & 0,02 & 0,01 & 0,20 \\
\hline $\mathrm{Pb}$ & $<0,02$ & $\mathrm{n.d}$ & 0,10 & 0,40 & 0,50 \\
\hline $\mathrm{Zn}$ & 0,41 & 0,59 & 0,40 & 0,50 & 5,00 \\
\hline $\mathrm{Ni}$ & 0,02 & 0,06 & 0,20 & 0,10 & 2,00 \\
\hline $\mathrm{Ba}$ & 0,24 & 1,80 & 0,30 & 1,10 & 5,00 \\
\hline $\mathrm{Ca}$ & $\mathbf{1 4 , 9 0}$ & $\mathbf{7 4 , 6 0}$ & $\mathbf{2 6 , 0 0}$ & $\mathbf{6 1 , 0 0}$ & \\
\hline $\mathrm{Cr}$ & 0,13 & 0,07 & 0,09 & 0,01 & 5,00 \\
\hline $\mathrm{Cu}$ & 0,06 & 0,11 & 0,05 & 0,07 & 1,00 \\
\hline $\mathrm{V}$ & n.d. & 0,08 & 0,70 & 0,40 & \\
\hline $\mathrm{Co}$ & n.d. & 0,02 & 0,10 & n.d. & \\
\hline
\end{tabular}

n.d. - não detectado

Fonte: Art. 18 (SÃO PAULO, 1976d) 


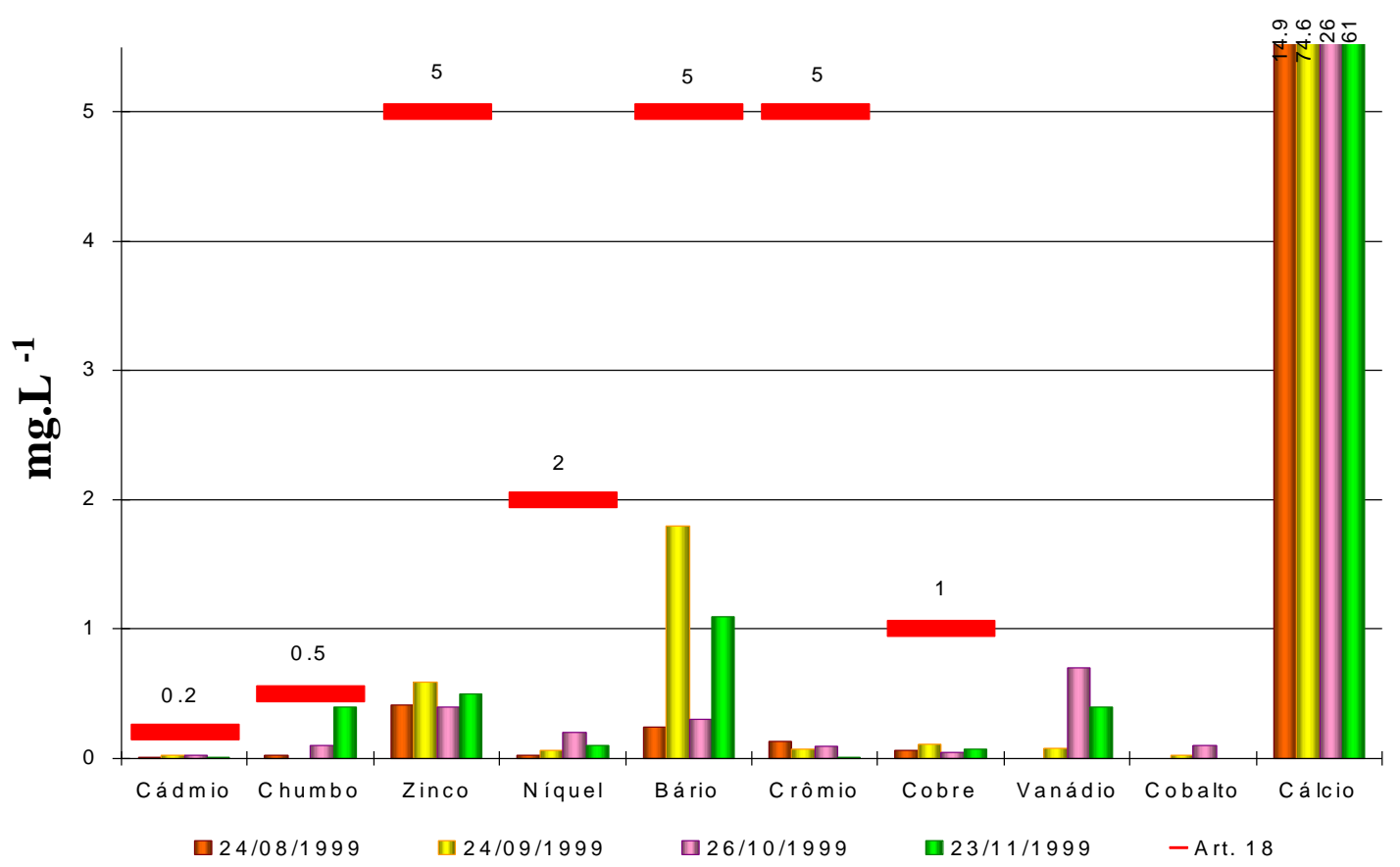

Figura 19: Representação gráfica dos resultados das análises químicas por espectrometria de absorção atômica realizadas no efluente líquido do setor de moagem das matérias-primas naturais (B-1)

O ponto B-2 (preparação de tintas e vidrados, FIG.9) apresentou resultado tóxico negativo (TAB.19, 20, 21). Neste mesmo ponto, durante a elaboração do prognóstico ambiental, os testes de toxicidade foram positivos apresentando valores baixos da CE 50\% como 5,20\% (TAB.10) e 18,50\% (TAB.11). A variação dos resultados do teste de toxicidade pode estar relacionada com os tipos de insumos de decoração utilizados, as tabelas $16 \mathrm{e}$ 18 ilustram a variação na composição química destas matérias-primas sintéticas. Nestas tabelas, encontram-se insumos contendo elevados teores de chumbo, boro, zinco, bário, crômio, magnésio, fósforo, zircônio, potássio, cálcio e titânio. O teor de zircônio apresentado na tabela 17 é o maior em relação aos 
demais resíduos sólidos analisados, indicando um eventual desperdício de matéria-prima sintética opacificante. Ainda observando as análises químicas do resíduo sólido deste ponto, verificam-se teores elevados de potássio, sódio, cálcio e zinco (TAB.17, 18). As análises químicas deste efluente líquido (TAB.23) (FIG.20), ocasionalmente, apresentaram valores muito altos, principalmente para o chumbo e o zinco. O bário, apesar dos valores abaixo do limite estabelecido pela legislação, eventualmente também ultrapassa os limites legais. Pode-se verificar uma diminuição na concentração do chumbo de 41,00mg. $\mathrm{L}^{-1}$ a 8,10mg. $\mathrm{L}^{-1}$. Outros metais como zinco, bário, cálcio e crômio, também apresentam diminuição na concentração no período analisado.

Tabela 23: Comparação das análises químicas realizadas por espectrometria de absorção atômica no efluente líquido do ponto B-2 (preparação de tintas e vidrados). Amostras coletadas em diferentes dias. Valores expressos em $\mathrm{mg} . \mathrm{L}^{-1}$

\begin{tabular}{l|r|r|r|r|r}
\hline \multicolumn{1}{c|}{ Metais } & \multicolumn{1}{c|}{$\mathbf{2 4 / 0 8 / 9 9}$} & \multicolumn{1}{c}{$\mathbf{2 4 / 0 9 / 9 9}$} & \multicolumn{1}{c}{$\mathbf{2 6 / 1 0 / 9 9}$} & \multicolumn{1}{c}{$\mathbf{2 3 / 1 1 / 9 9}$} & \multicolumn{1}{c}{ Art. 18 } \\
\hline $\mathrm{Cd}$ & 0,01 & 0,02 & 0,02 & 0,02 & 0,20 \\
\hline $\mathrm{Pb}$ & $\mathbf{4 1 , 0 0}$ & $\mathbf{2 , 0 0}$ & $\mathbf{2 , 0 0}$ & $\mathbf{8 , 1 0}$ & 0,50 \\
\hline $\mathrm{Zn}$ & $\mathbf{3 3 , 8 0}$ & $\mathbf{1 5 , 7 0}$ & $\mathbf{6 , 0 0}$ & $\mathbf{6 , 0 0}$ & 5,00 \\
\hline $\mathrm{Ni}$ & 0,29 & 0,27 & 0,20 & 0,10 & 2,00 \\
\hline $\mathrm{Ba}$ & $\mathbf{1 0 , 6 0}$ & 4,40 & 1,60 & 3,30 & 5,00 \\
\hline $\mathrm{Ca}$ & 52,90 & 34,70 & 33,00 & 45,00 & \\
\hline $\mathrm{Cr}$ & 0,14 & 0,03 & 0,05 & n.d. & 5,00 \\
\hline $\mathrm{Cu}$ & 0,05 & n.d. & 0,01 & n.d. & 1,00 \\
\hline $\mathrm{V}$ & 0,16 & n.d. & 0,70 & 0,20 & \\
\hline $\mathrm{Co}$ & n.d. & 0,05 & 0,10 & n.d. & \\
\hline
\end{tabular}

n.d. - não detectado

Fonte: Art. 18 (SÃO PAULO, 1976d) 


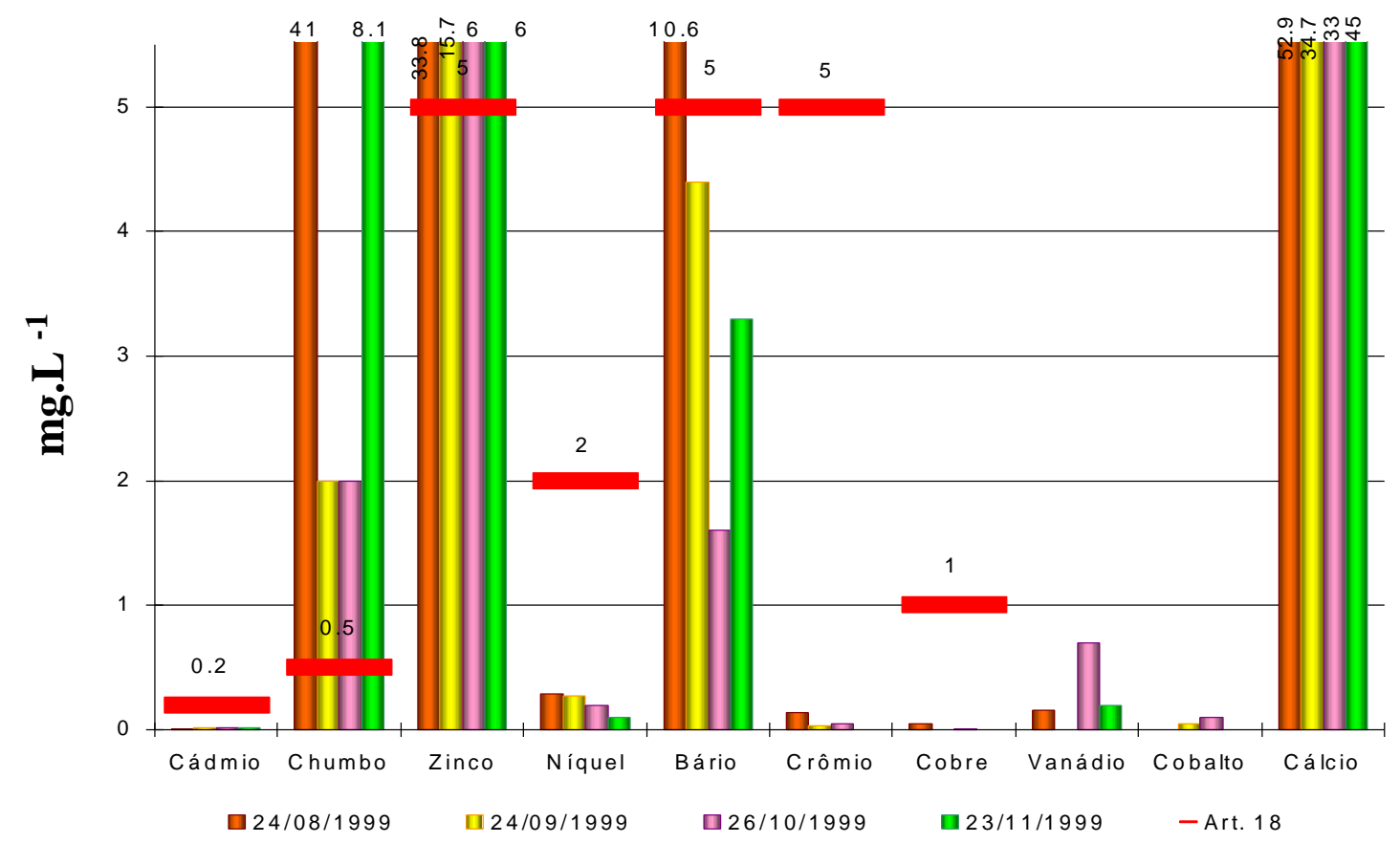

Figura 20: Representação gráfica dos resultados das análises químicas por espectrometria de absorção atômica realizadas no efluente líquido do setor de preparação de tintas e vidrados (B-2)

No ponto B-3 (efluente líquido da linha de decoração do setor de monoqueima, FIG.9), o teste de toxicidade foi negativo (TAB.19, 20, 21). No entanto, observando-se os resultados das análises químicas (TAB.24) (FIG.21), verifica-se que a concentração de chumbo está acima do limite máximo permitido e que a concentração do chumbo aumentou em relação aos meses 08/99 e 10/99. Pode-se supor que a contaminação, com metais tóxicos, no ponto B-3 é proveniente dos insumos utilizados na linha de decoração das peças cerâmicas da monoqueima (TAB.16, 18). O resíduo sólido decantado deste efluente líquido (TAB.17) também apresenta teor elevado de zircônio. 
Tabela 24: Comparação das análises químicas realizadas por espectrometria de absorção atômica no efluente líquido do ponto B-3 (efluente líquido da linha de decoração do setor de monoqueima). Amostras coletadas em diferentes dias. Valores expressos em $\mathrm{mg} \cdot \mathrm{L}^{-1}$

\begin{tabular}{l|r|r|r|r|r}
\hline \multicolumn{1}{c|}{ Metais } & $\mathbf{2 4 / 0 8 / 9 9}$ & \multicolumn{1}{|c|}{$\mathbf{2 4 / 0 9 / 9 9}$} & \multicolumn{1}{c|}{$\mathbf{2 6 / 1 0 / 9 9}$} & $\mathbf{2 3 / 1 1 / 9 9}$ & \multicolumn{1}{c}{ Art. 18 } \\
\hline $\mathrm{Cd}$ & 0,01 & 0,03 & 0,01 & 0,01 & 0,20 \\
\hline $\mathrm{Pb}$ & $\mathbf{1 , 4 4}$ & $\mathbf{6 , 7 0}$ & $\mathbf{1 , 3 0}$ & $\mathbf{2 , 8 0}$ & 0,50 \\
\hline $\mathrm{Zn}$ & $\mathbf{1 2 , 1 0}$ & $\mathbf{1 0 , 2 0}$ & $\mathbf{8 , 0 0}$ & $\mathbf{8 , 0 0}$ & 5,00 \\
\hline $\mathrm{Ni}$ & 0,22 & 0,26 & 0,30 & 0,20 & 2,00 \\
\hline $\mathrm{Ba}$ & 2,30 & 2,90 & 2,20 & 0,80 & 5,00 \\
\hline $\mathrm{Ca}$ & 18,70 & 65,5 & 23,00 & 43,00 & \\
\hline $\mathrm{Cr}$ & 0,12 & 0,08 & 0,04 & n.d. & 5,00 \\
\hline $\mathrm{Cu}$ & 0,16 & $<0,02$ & n.d. & n.d. & 1,00 \\
\hline $\mathrm{V}$ & 0,08 & n.d. & $0,90$. & 0,30 & \\
\hline $\mathrm{Co}$ & n.d. & 0,21 & 0,20 & n.d. & \\
\hline
\end{tabular}

n.d. - não detectado

Fonte: Art. 18 (SÃO PAULO, 1976d)

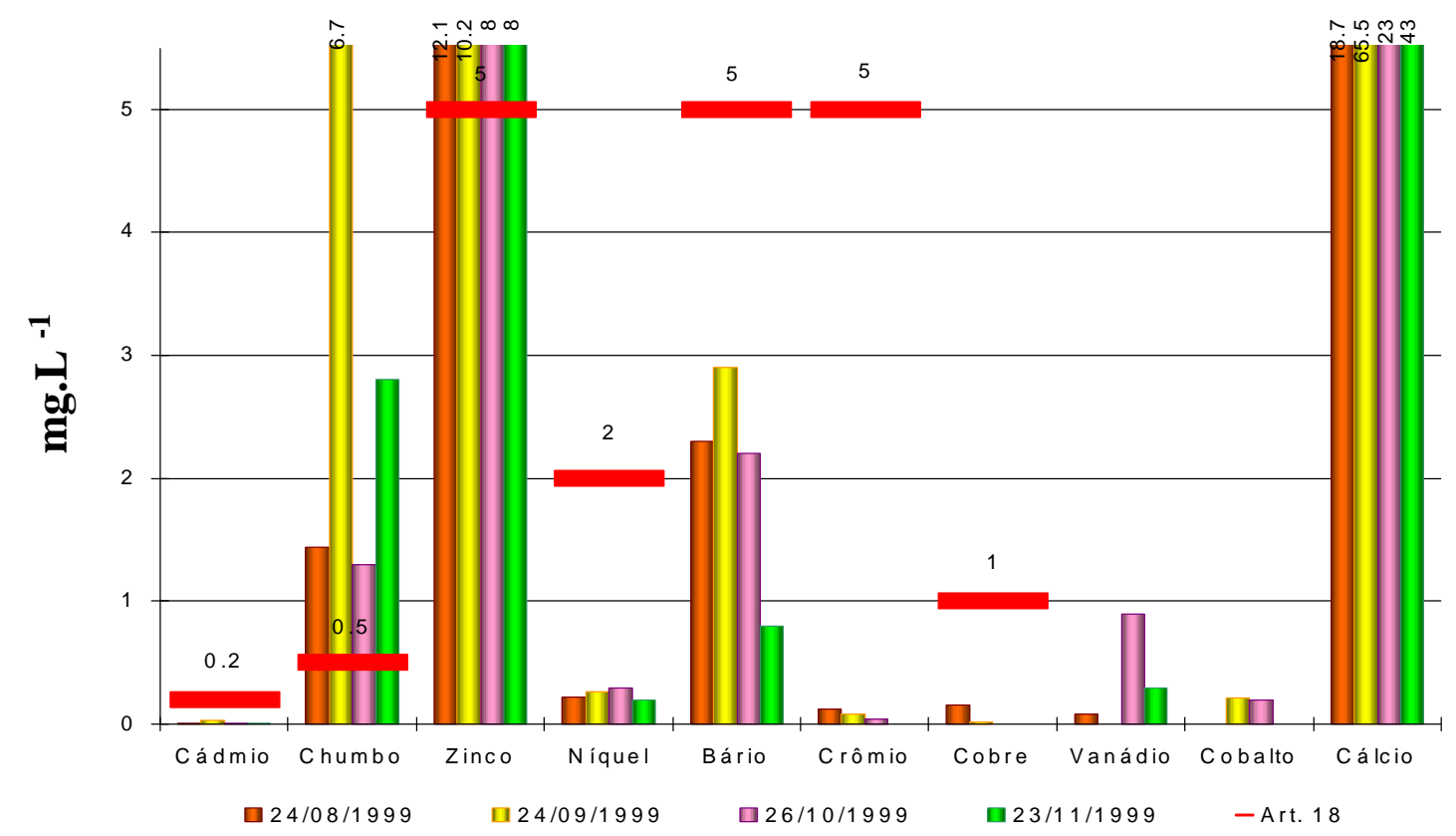

Figura 21: Representação gráfica dos resultados das análises químicas por espectrometria de absorção atômica realizadas no efluente líquido da linha de decoração da monoquiema (B-3) 
No ponto B-4 (efluente líquido do setor de biqueima - ponto de liberação para a rede pública de esgoto, FIG.9) o resultado tóxico se repetiu em todos os testes de toxicidade realizados para sua caracterização (TAB.19, 20, 21). Observando-se as análises químicas deste ponto (TAB.25) (FIG.22), notase que a concentração de chumbo é sempre acima do limite máximo permissível. Verificou-se que as concentrações de cádmio e cobre também superam este limite. Nas tabelas 16 e 18 podem ser observadas as variações de insumos, pois apresentam resultados de amostras coletadas em tempos diferentes, quando da fabricação de produtos diferentes. Estas tabelas mostram ainda que a massa de decoração utilizada no setor de biqueima apresenta concentração elevada de chumbo, zinco, zircônio, cobalto, potássio e sódio. Observando-se a tabela 17, verifica-se que os óxidos de chumbo e de bário não foram identificados e os teores dos óxidos de níquel, de zinco e de crômio apresentam valores abaixo de $1 \%$. Com os resultados das análises químicas das matérias-primas sintéticas, dos resíduos sólidos, do efluente líquido, verificando-se que todos os testes de toxicidade realizados neste ponto foram positivos, pode-se concluir que os elementos tóxicos, provenientes das matérias-primas sintéticas, estão, em sua maioria, dispersos no meio aquoso. Com todos estes resultados e, considerando que não há tanques de decantação neste ponto e que a vazão média medida foi de, aproximadamente, $500 \mathrm{~L} / \mathrm{h}$, pode-se considerar que este ponto de lançamento de efluente líquido é o mais crítico da indústria estudada. 
Tabela 25: Comparação das análises químicas realizadas por espectrometria de absorção atômica no efluente líquido do ponto B-4 (efluente líquido do setor de biqueima - ponto de liberação para a rede pública de esgoto). Amostras coletadas em diferentes dias. Valores expressos em mg. $\mathrm{L}^{-1}$

\begin{tabular}{l|r|r|r|r|r}
\hline \multicolumn{1}{c|}{ Metais } & $\mathbf{2 4 / 0 8 / 9 9}$ & \multicolumn{1}{|c|}{$\mathbf{2 4 / 0 9 / 9 9}$} & $\mathbf{2 6 / 1 0 / 9 9}$ & $\mathbf{2 3 / 1 1 / 9 9}$ & \multicolumn{1}{c}{ Art. 18 } \\
\hline $\mathrm{Cd}$ & 0,02 & $\mathbf{1 , 5 0}$ & $\mathbf{0 , 2 2}$ & 0,03 & 0,20 \\
\hline $\mathrm{Pb}$ & $\mathbf{1 , 2 3}$ & $\mathbf{4 5 , 6 0}$ & $\mathbf{3 3 , 0 0}$ & $\mathbf{0 , 9 0}$ & 0,50 \\
\hline $\mathrm{Zn}$ & 1,10 & 1,90 & $\mathbf{7 , 0 0}$ & 1,00 & 5,00 \\
\hline $\mathrm{Ni}$ & 0,01 & 0,11 & n.d. & 0,20 & 2,00 \\
\hline $\mathrm{Ba}$ & 0,21 & 0,60 & 2,50 & 0,30 & 5,00 \\
\hline $\mathrm{Ca}$ & 18,40 & 20,40 & 22,00 & 20,00 & \\
\hline $\mathrm{Cr}$ & 0,11 & 0,09 & 0,05 & 0,01 & 5,00 \\
\hline $\mathrm{Cu}$ & 0,61 & $\mathbf{1 , 9 0}$ & $\mathbf{1 , 6 0}$ & $\mathbf{1 , 9 0}$ & 1,00 \\
\hline $\mathrm{V}$ & 0,30 & n.d. & 1,10 & 0,50 & \\
\hline $\mathrm{Co}$ & n.d. & 0,28 & 0,40 & n.d. & \\
\hline
\end{tabular}

n.d. - não detectado

Fonte: Art. 18 (SÃO PAULO, 1976d)

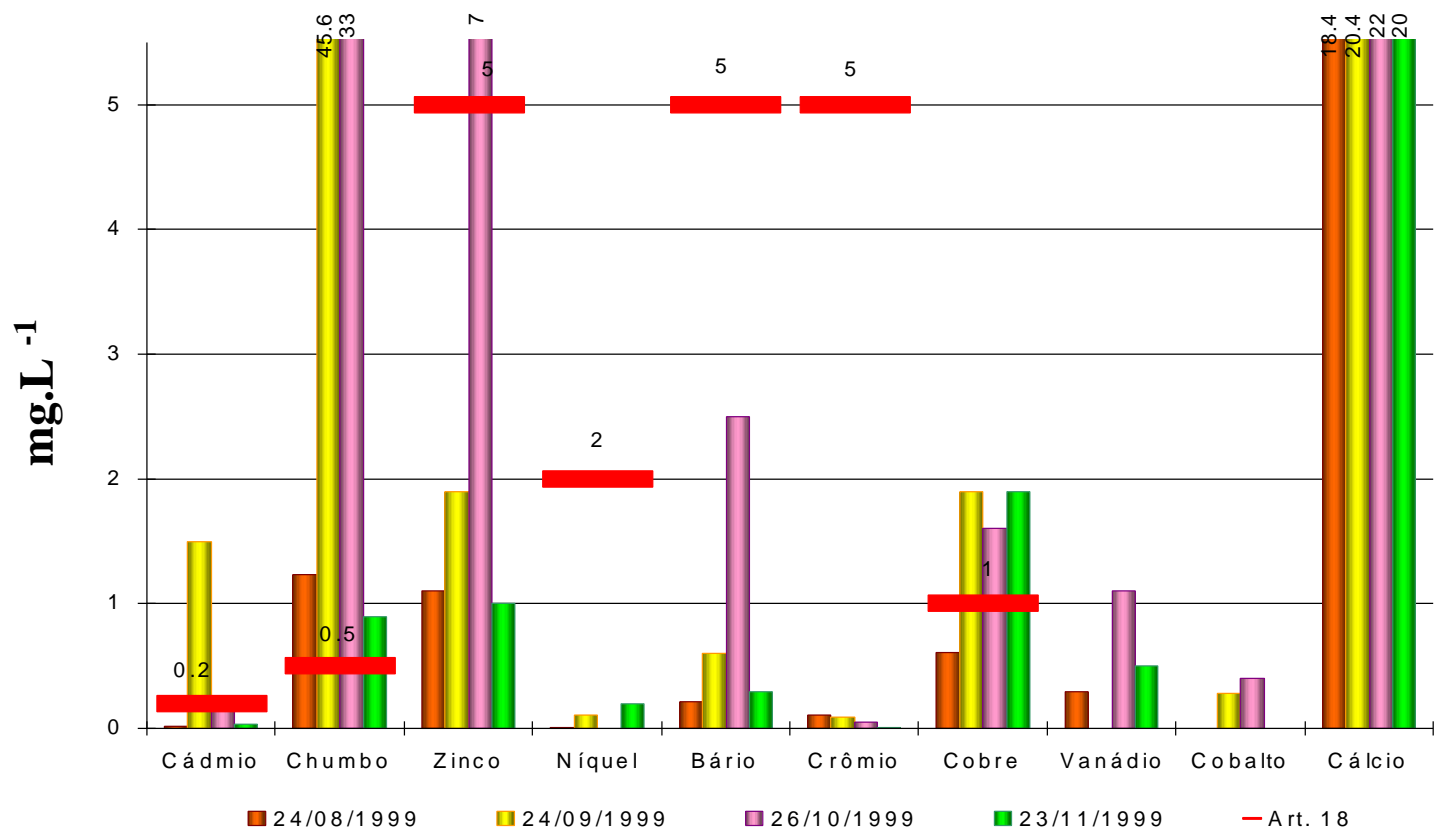

Figura 22: Representação gráfica dos resultados das análises químicas por espectrometria de absorção atômica realizadas no efluente líquido do setor de biqueima (B-4) 
No ponto B-5 (ponto de liberação para a rede pública de esgoto, FIG.9), o teste de toxicidade foi negativo (TAB.19, 20,21), porém, as concentrações de chumbo e zinco (TAB.26) (FIG.23) estão acima dos limites estabelecidos pelo artigo 18 da Legislação Estadual (SÃO PAULO, 1976d). Verifica-se que a concentração de chumbo aumenta nos três primeiros meses e em seguida tem uma queda, continuando, porém, acima dos limites legais. As concentrações de zinco se intercalam acima e abaixo dos limites no período analisado. Os metais tóxicos detectados são provenientes dos efluentes líquidos dos pontos B-3 (linha de decoração da monoqueima) e B-7 (laboratórios de controle de qualidade), os quais são lançados no ponto B-5.

Tabela 26: Comparação das análises químicas realizadas por espectrometria de absorção atômica no efluente líquido do ponto B-5 (ponto de liberação para a rede pública de esgoto). Amostras coletadas em diferentes dias. Valores expressos em mg. $\mathrm{L}^{-1}$

\begin{tabular}{l|r|r|r|r|r}
\hline \multicolumn{1}{c|}{ Metais } & $\mathbf{2 4 / 0 8 / 9 9}$ & \multicolumn{1}{c|}{$\mathbf{2 4 / 0 9 / 9 9}$} & \multicolumn{1}{c|}{$\mathbf{2 6 / 1 0 / 9 9}$} & $\mathbf{2 3 / 1 1 / 9 9}$ & \multicolumn{1}{c}{ Art. 18 } \\
\hline $\mathrm{Cd}$ & 0,01 & $<0,01$ & 0,02 & 0,01 & 0,20 \\
\hline $\mathrm{Pb}$ & $\mathbf{0 , 6 0}$ & $\mathbf{1 , 2 0}$ & $\mathbf{4 , 0 0}$ & $\mathbf{2 , 9 0}$ & 0,50 \\
\hline $\mathrm{Zn}$ & $\mathbf{1 1 , 8 0}$ & 4,50 & $\mathbf{1 1 , 0 0}$ & 3,00 & 5,00 \\
\hline $\mathrm{Ni}$ & n.d. & n.d. & 0,20 & 0,20 & 2,00 \\
\hline $\mathrm{Ba}$ & 3,20 & 0,80 & 2,50 & 0,60 & 5,00 \\
\hline $\mathrm{Ca}$ & 12,60 & 18,40 & 39,00 & 21,00 & \\
\hline $\mathrm{Cr}$ & 0,03 & $<0,02$ & 0,04 & 0,01 & 5,00 \\
\hline $\mathrm{Cu}$ & 0,02 & n.d. & n.d. & n.d. & 1,00 \\
\hline $\mathrm{V}$ & 0,18 & 0,13 & 1,10 & 0,90 & \\
\hline $\mathrm{Co}$ & n.d. & n.d. & 0,15 & n.d. & \\
\hline
\end{tabular}

n.d. - não detectado

Fonte: Art. 18 (SÃO PAULO, 1976d) 


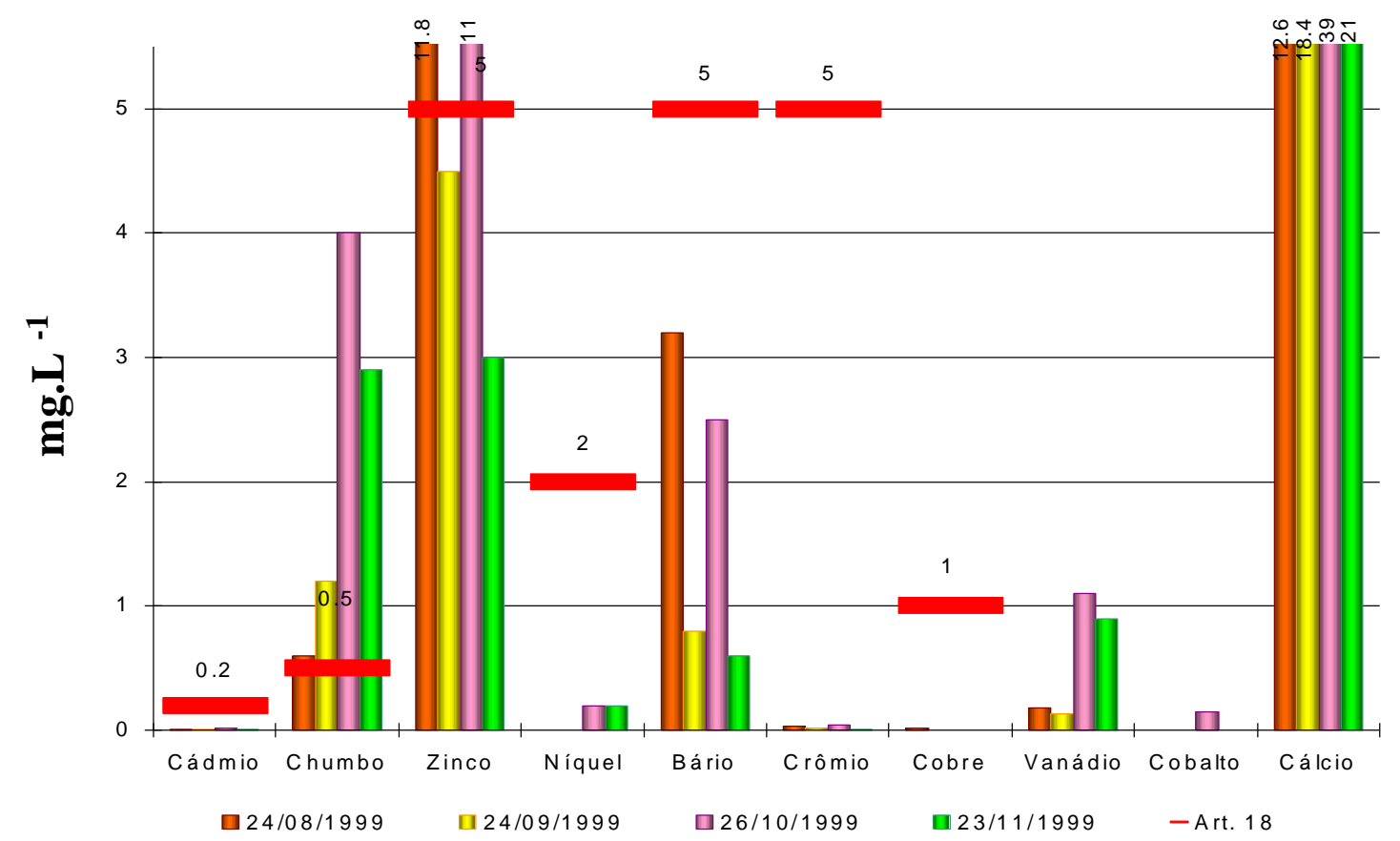

Figura 23: Representação gráfica dos resultados das análises químicas por espectrometria de absorção atômica realizadas no efluente líquido da caixa de coleta dos efluentes líquidos da linha de decoração da monoqueima e do laboratório de controle de qualidade (B-5)

Observando-se os resultados das análises químicas realizadas na água de abastecimento (ponto B-6, FIG.9), apresentados pela tabela 27 e figura 24 , nota-se que a concentração de cálcio sempre encontra-se alta. No caso do zinco, níquel e vanádio as concentrações chamam a atenção por apresentarem valores equivalentes aos encontrados nos efluentes líquidos. De acordo com os limites máximos permissíveis para água potável Portaria n³6/GM - Secretaria de Estado da Saúde (SÃO PAULO, 1976f), verifica-se que a concentração de cádmio, na maioria dos resultados, apresentou-se elevada e a concentração chumbo, em um dos resultados, estava elevada. Por apresentar pelo menos um resultado positivo para toxicidade (TAB.21), foram medidos alguns fatores 
que interferem na toxicidade da amostra, como dureza $\left(23,14 \mathrm{mg} \cdot \mathrm{L}^{-1} \mathrm{CaCO}_{3}\right)$, pH $(7,11)$, oxigênio dissolvido na amostra $\left(5,56 \mathrm{mg}^{-\mathrm{L}^{-1}}\right)$ e oxigênio dissolvido na água de diluição $\left(6,42 \mathrm{mg} \cdot \mathrm{L}^{-1}\right)$. Porém, com estes resultados, não se justificaram os resultados positivos para toxicidade. Desta forma, mediu-se a concentração de cloro residual $(0,02 \mathrm{ppm})$ e cloro livre $(0,02 \mathrm{ppm})$, que também interferem nos resultados dos testes de toxicidade. Devido às baixas concentrações de cloro encontradas na amostra da água de abastecimento, por interferir negativamente no processo de fabricação, foram realizados testes de presença ou ausência de coliformes totais, com resultado positivo. Estes dados parecem justificar a toxicidade positiva detectada na água de abastecimento da indústria.

Tabela 27: Comparação das análises químicas realizadas por espectrometria de absorção atômica no efluente líquido do ponto B-6 (água de abastecimento) e os limites máximos permissíveis para água potável Portaria $n^{\circ}$ 36/GM - Secretaria de Estado da Saúde. Amostras coletadas em diferentes dias. Valores expressos em mg. L $^{-1}$

\begin{tabular}{|c|c|c|c|c|c|}
\hline Metais & $24 / 08 / 99$ & 24/09/99 & 26/10/99 & $23 / 11 / 99$ & $\begin{array}{c}\text { Portaria } \\
n^{\circ} 36 \mathrm{GM}\end{array}$ \\
\hline $\mathrm{Cd}$ & 0,01 & $<0,01$ & 0,01 & 0,01 & 0,005 \\
\hline $\mathrm{Pb}$ & n.d. & 0,15 & n.d. & 0,04 & 0,05 \\
\hline $\mathrm{Zn}$ & 0,57 & 2,10 & 0,40 & 0,40 & 5,00 \\
\hline $\mathrm{Ni}$ & n.d. & n.d. & 0,10 & 0,20 & 2,00 \\
\hline $\mathrm{Ba}$ & n.d. & 0,05 & 0,03 & 0,02 & 1,00 \\
\hline $\mathrm{Ca}$ & 1,40 & 4,10 & 3,50 & 4,00 & \\
\hline $\mathrm{Cr}$ & 0,03 & n.d. & 0,01 & n.d. & 0,05 \\
\hline $\mathrm{Cu}$ & 0,01 & n.d. & n.d. & n.d. & 1,00 \\
\hline $\mathrm{V}$ & 0,15 & 0,28 & 1,20 & 0,06 & \\
\hline Co & n.d. & n.d. & 0,02 & n.d. & \\
\hline
\end{tabular}




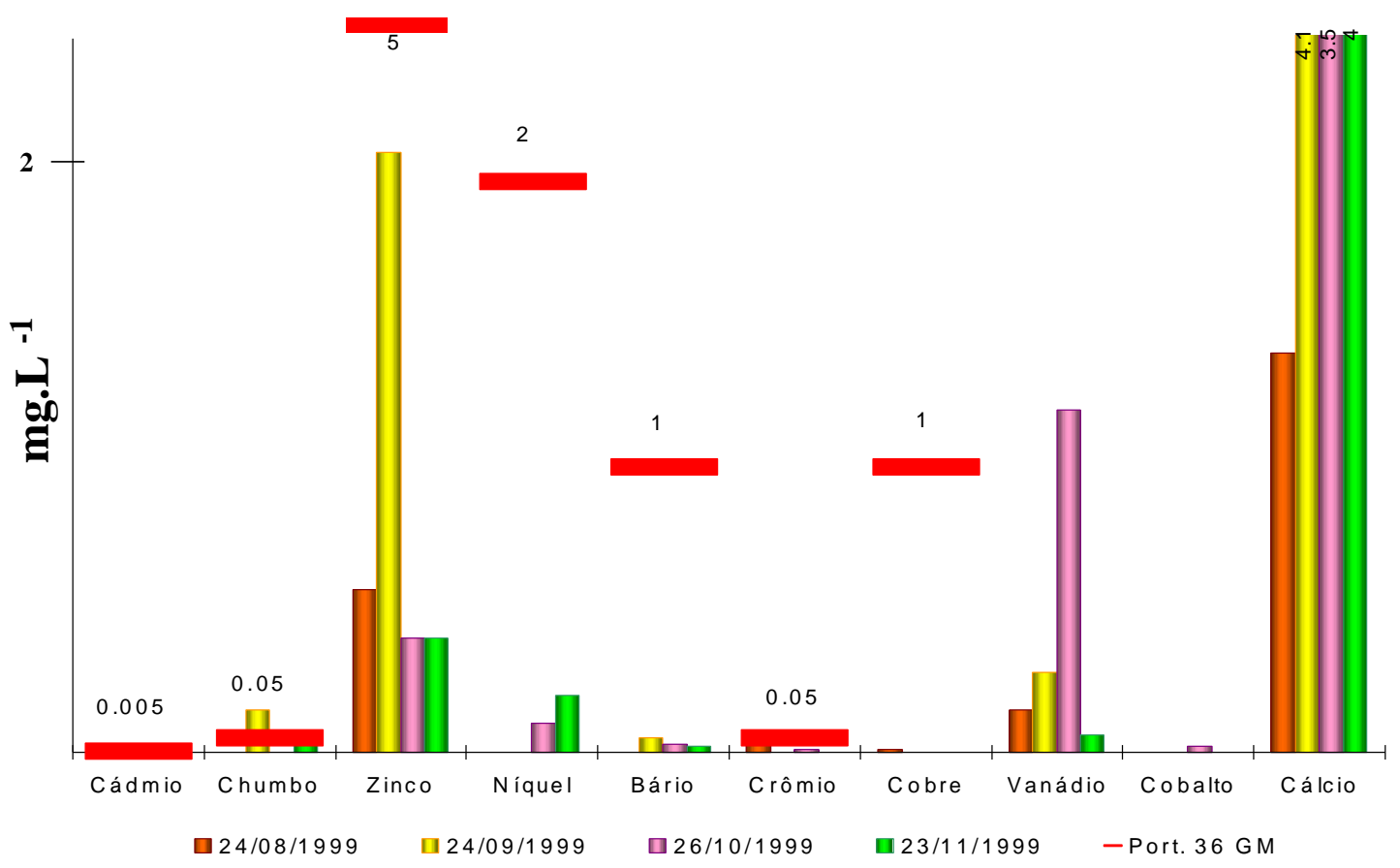

Figura 24: Representação gráfica dos resultados das análises químicas por espectrometria de absorção atômica realizadas na água de abastecimento (B-6)

No ponto B-7 (efluente líquido do laboratório do controle de qualidade, FIG.9), os resultados das análises químicas (TAB.28) (FIG.25) revelaram altas concentrações de metais como chumbo, zinco, bário e cálcio. Nota-se um aumento significativo na concentração de chumbo. A concentração de zinco, mesmo diminuindo de $107,60 \mathrm{mg} \cdot \mathrm{L}^{-1}$ para $26,00 \mathrm{mg} \cdot \mathrm{L}^{-1}$ e aumentando, em seguida, para $87,00 \mathrm{mg} \cdot \mathrm{L}^{-1}$, foram as maiores concentrações obtidas em relação aos demais efluentes líquidos analisados. A mesma comparação aos demais efluentes líquidos pode ser feita em relação às concentrações de cálcio. Estes resultados reforçam a necessidade de se implantar medidas corretivas no que se refere ao lançamento do efluente líquido do laboratório de controle de qualidade da indústria. Em uma das amostragens o resultado do 
teste de toxicidade foi positivo (TAB.20). A mudança dos tipos de insumos utilizados pode minimizar o problema, além da contenção e tratamento do efluente líquido, antes de ser despejado no ponto B-5.

Tabela 28: Comparação das análises químicas realizadas por espectrometria de absorção atômica no efluente líquido do ponto B-7 (efluente líquido do laboratório do controle de qualidade). Amostras coletadas em diferentes dias. Valores expressos em mg. $\mathrm{L}^{-1}$

\begin{tabular}{l|r|r|r|r|r}
\hline \multicolumn{1}{c|}{ Metais } & $\mathbf{2 4 / 0 8 / 9 9}$ & \multicolumn{1}{|c|}{$\mathbf{2 4 / 0 9 / 9 9}$} & \multicolumn{1}{|c|}{$\mathbf{2 6 / 1 0 / 9 9}$} & $\mathbf{2 3 / 1 1 / 9 9}$ & \multicolumn{1}{c}{ Art. 18 } \\
\hline $\mathrm{Cd}$ & 0,02 & 0,09 & 0,07 & 0,03 & 0,20 \\
\hline $\mathrm{Pb}$ & $\mathbf{6 , 5 4}$ & $\mathbf{2 7 , 8 0}$ & $\mathbf{6 , 0 0}$ & $\mathbf{6 0 , 0 0}$ & 0,50 \\
\hline $\mathrm{Zn}$ & $\mathbf{1 0 7 , 6 0}$ & $\mathbf{9 0 , 9 0}$ & $\mathbf{2 6 , 0 0}$ & $\mathbf{8 7 , 0 0}$ & 5,00 \\
\hline $\mathrm{Ni}$ & 0,05 & 0,13 & 0,13 & 0,50 & 2,00 \\
\hline $\mathrm{Ba}$ & $\mathbf{2 5 , 0 0}$ & $\mathbf{1 8 , 9 0}$ & 1,30 & $\mathbf{2 9 , 0 0}$ & 5,00 \\
\hline $\mathrm{Ca}$ & 72,90 & 343,40 & 82,00 & 144,00 & \\
\hline $\mathrm{Cr}$ & 0,06 & 0,19 & 0,03 & 0,06 & 5,00 \\
\hline $\mathrm{Cu}$ & 0,04 & 0,43 & 0,05 & 0,13 & 1,00 \\
\hline $\mathrm{V}$ & 0,27 & 0,35 & $\mathrm{n} . \mathrm{d}$ & 0,04 & \\
\hline $\mathrm{Co}$ & n.d & 0,13 & 0,10 & 0,22 & \\
\hline
\end{tabular}

n.d. - não detectado

Fonte: Art. 18 (SÃO PAULO, 1976d) 


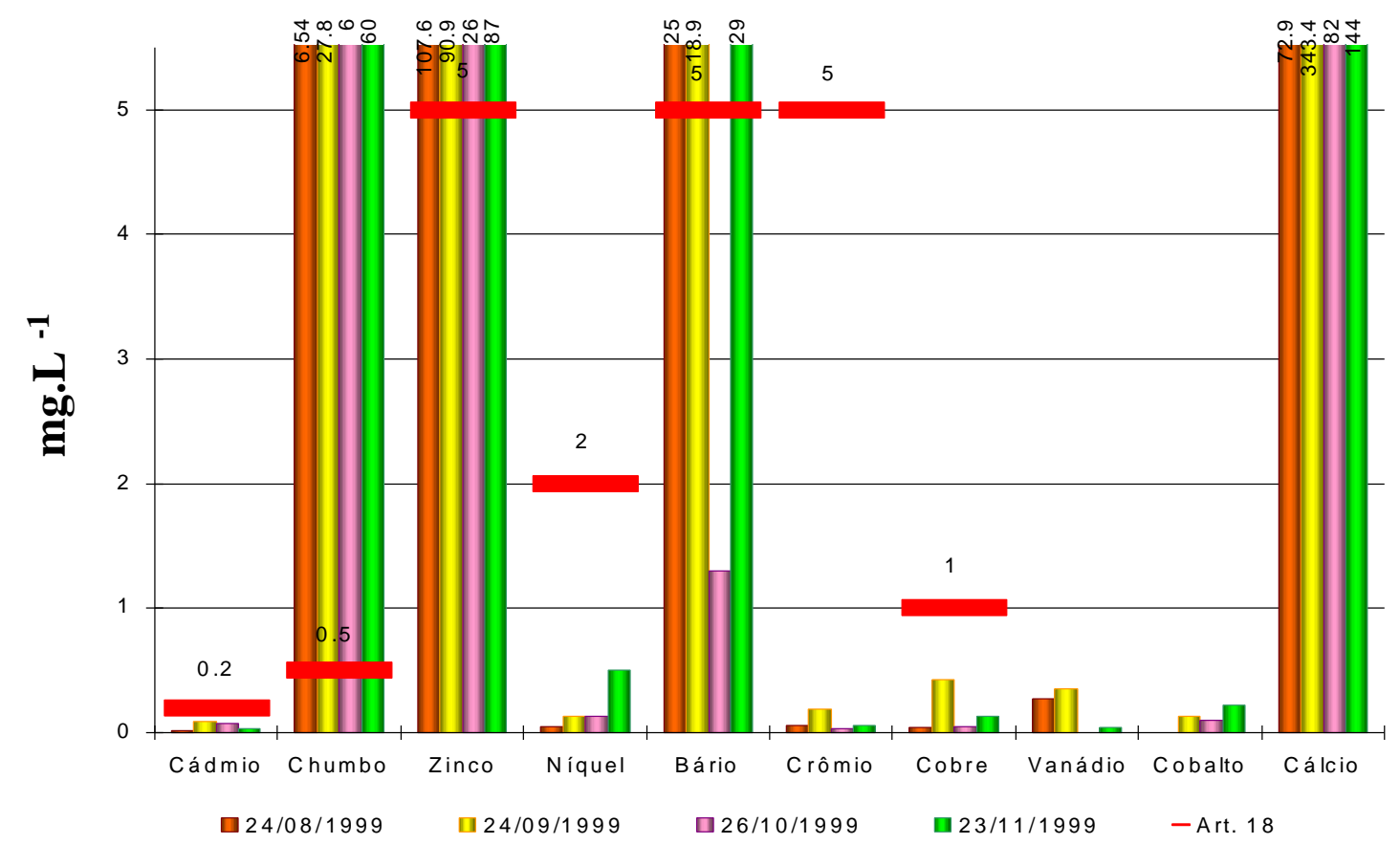

Figura 25: Representação gráfica dos resultados das análises químicas por espectrometria de absorção atômica realizadas no efluente líquido do laboratório de controle de qualidade (B-7)

A mesma oscilação dos resultados positivos e negativos dos testes de toxicidade (TAB.19, 20, 21) ocorre no ponto B-8 (efluente líquido da linha de decoração do setor de biqueima, FIG.9). Com os dados fornecidos pelas análises químicas deste efluente líquido (TAB.29) (FIG.26), verificam-se que metais como zinco e cálcio apresentam concentrações elevadas, provavelmente devido ao desperdício de insumos. Verifica-se também que, no último mês de coleta, a concentração de chumbo atingiu o valor limite estipulado pela legislação, enquanto que a concentração do bário teve um aumento de $0,83 \mathrm{mg} \cdot \mathrm{L}^{-1}$ para $13,00 \mathrm{mg} \cdot \mathrm{L}^{-1}$, vindo a diminuir para $0,40 \mathrm{mg} \cdot \mathrm{L}^{-1}$ no mês seguinte. 
Tabela 29: Comparação das análises químicas realizadas por espectrometria de absorção atômica no efluente líquido do ponto B-8 (efluente líquido da linha de decoração do setor de biqueima). Amostras coletadas em diferentes dias. Valores expressos em mg. L $^{-1}$

\begin{tabular}{l|r|r|r|r|r}
\hline \multicolumn{1}{c|}{ Metais } & $\mathbf{2 4 / 0 8 / 9 9}$ & \multicolumn{1}{c|}{$\mathbf{2 4 / 0 9 / 9 9}$} & $\mathbf{2 6 / 1 0 / 9 9}$ & \multicolumn{1}{c}{$\mathbf{2 3 / 1 1 / 9 9}$} & \multicolumn{1}{c}{ Art. 18 } \\
\hline $\mathrm{Cd}$ & 0,01 & $<0,01$ & 0,01 & 0,01 & 0,20 \\
\hline $\mathrm{Pb}$ & 0,07 & 0,24 & 0,15 & $\mathbf{0 , 5 0}$ & 0,50 \\
\hline $\mathrm{Zn}$ & $\mathbf{1 0 , 9 0}$ & 4,50 & $\mathbf{3 4 , 0 0}$ & 1,40 & 5,00 \\
\hline $\mathrm{Ni}$ & n.d. & 0,02 & 0,10 & 0,20 & 2,00 \\
\hline $\mathrm{Ba}$ & 2,50 & 0,83 & $\mathbf{1 3 , 0 0}$ & 0,40 & 5,00 \\
\hline $\mathrm{Ca}$ & 6,50 & 5,90 & 17,00 & 12,00 & \\
\hline $\mathrm{Cr}$ & 0,03 & $<0,02$ & n.d. & 0,02 & 5,00 \\
\hline $\mathrm{Cu}$ & n.d. & n.d. & 0,20 & 0,07 & 1,00 \\
\hline $\mathrm{V}$ & 0,16 & 0,10 & 0,20 & 0,10 & \\
\hline $\mathrm{Co}$ & n.d & n.d. & 0,30 & 0,03 & \\
\hline
\end{tabular}

n.d. - não detectado

Fonte: Art. 18 (SÃO PAULO, 1976d)

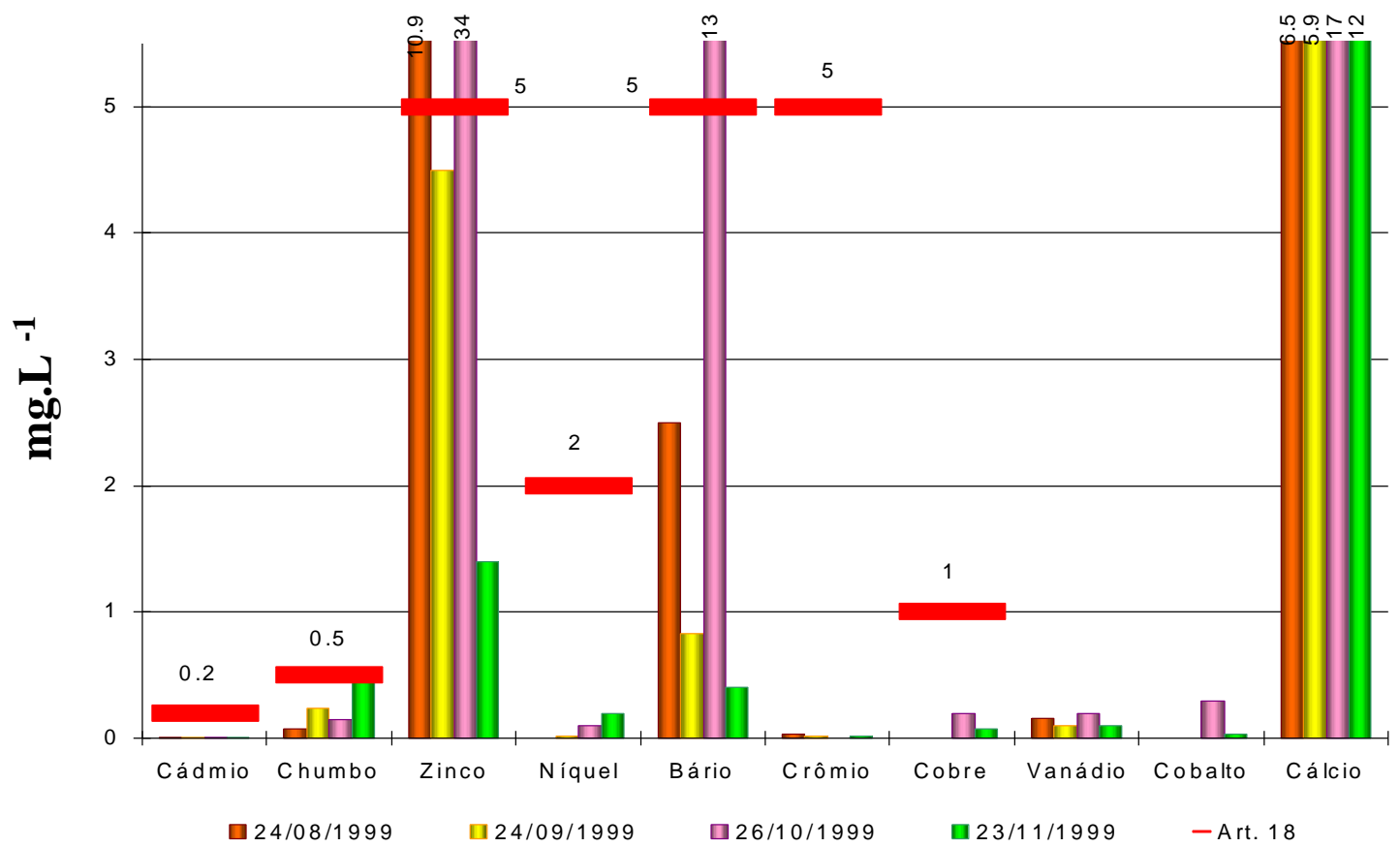

Figura 26: Representação gráfica dos resultados das análises químicas por espectrometria de absorção atômica realizadas no efluente líquido da linha de decoração da biqueima (B-8) 
Estas comparações dos dados obtidos durante o período de coleta e análise das amostras, demonstra a variação na composição química dos insumos utilizados durante 0 processo de fabricação de revestimentos cerâmicos. Em todos os efluentes analisados observa-se o comportamento oscilatório nas concentrações dos metais analisados.

\section{IV.2.3. Discussão sobre a Eficiência da Metodologia das Matrizes em Relação aos Dados Analíticos}

A avaliação ambiental foi realizada utilizando-se o método das matrizes e métodos analíticos. Os resultados analíticos comprovaram os prognósticos obtidos pelas matrizes (TAB.30). Assim sendo, a realização de um prognóstico ambiental mostrou-se um importante instrumento para a elaboração de um planejamento analítico de controle e monitoramento dos resíduos e efluentes gerados.

Tabela 30: Comparação dos resultados obtidos nos pontos críticos identificados pela metodologia das matrizes e pelos dados analíticos

\begin{tabular}{|c|c|}
\hline $\begin{array}{c}\text { PROGNOSTICO DOS ASPECTOS } \\
\text { AMBIENTAIS } \\
\text { (METODOLOGIA DAS MATRIZES) }\end{array}$ & $\begin{array}{c}\text { DIAGNOSSTICO DOS ASPECTOS } \\
\text { AMBIENTAIS } \\
\text { (DADOS ANALÍTICOS) }\end{array}$ \\
\hline PONTOS CRÍTICOS & PONTOS CRÍTICOS \\
\hline Lavagem dos moinhos PTV (B-2) & Lavagem dos moinhos PTV (B-2) \\
\hline Efluente líquido do setor de biqueima (B-4) & Efluente líquido do setor de biqueima (B-4) \\
\hline Laboratório de controle de qualidade (B-7) & Laboratório de controle de qualidade (B-7) \\
\hline Não determinado & $\begin{array}{l}\text { Lançamento para rede de esgoto de B-3 e } \\
\text { B-7 (B-5) }\end{array}$ \\
\hline Queima das peças cerâmicas & Não determinado \\
\hline
\end{tabular}


Verifica-se que os pontos críticos (B-2, B-4 e B-7) identificados com a avaliação ambiental realizada por meio das matrizes coincide com os identificados pelas análises químicas. O ponto B-5, por não apresentar resultado positivo no teste de toxicidade, não foi considerado como um ponto crítico pela avaliação com as matrizes. No entanto, as análises químicas revelaram que este ponto de coleta (B-5) é crítico, pois identificaram metais tóxicos em concentrações acima do limite máximo estabelecido pela legislação. Em relação ao setor de queima das peças cerâmicas, considerado um ponto crítico pela avaliação das matrizes, não foram realizadas análises nos efluentes gasosos para comprovar este resultado.

A metodologia de avaliação de impactos ambientais, na forma de matrizes, demonstrou ser um ótimo instrumento para a realização da caracterização do processo produtivo da indústria de placas de revestimentos cerâmicos, fornecendo dados preliminares para a elaboração de um planejamento de monitoramento e controle. Além disto, pela comparação dos dados obtidos antes e após a implantação das ações mitigadoras, a matriz pode servir como instrumento para verificação da eficiência dos programas implantados para a melhoria ambiental. 


\section{IV.2.4. Discussão sobre os Resultados dos Testes de Toxicidade e Análises Químicas nos Efluentes Líquidos}

Comparando-se os resultados dos testes de toxicidade com os resultados das análises químicas realizados nos efluentes líquidos da indústria cerâmica, notou-se que alguns efluentes não apresentavam toxicidade positiva, mesmo tendo concentrações elevadas de metais tóxicos obtidos pelas análises químicas, como ocorreu no ponto B-5, por exemplo.

É importante ressaltar que todos os testes de toxicidade foram realizados no efluente líquido sem que este sofresse qualquer tratamento prévio, ou seja, filtração, centrifugação, acerto de pH ou dureza, as amostras apenas foram conservadas sob temperatura de aproximadamente $4^{\circ} \mathrm{C}$ até a realização dos ensaios, realizados em temperatura ambiente de aproximadamente $20^{\circ} \mathrm{C}$. Por outro lado, as amostras destinadas às análises químicas foram conservadas com a adição de ácido nítrico concentrado até a obtenção de $\mathrm{pH}$ com valor abaixo de 2,0.

De acordo com os estudos relativos à biodisponibilidade dos metais pesados, a correlação destes dados tornou-se imprecisa, pois as condições dos metais contidos na amostra destinada aos testes de toxicidade se tornaram diferentes nas amostras destinadas as análises químicas, devido à adição do ácido. Para se ter uma correta interpretação das características toxicológicas dos efluentes líquidos, deve-se considerar a biodisponibilidade dos metais 
tóxicos presentes na amostra. Biodisponibilidade é definida por BENSON et al. (apud MATTIAZZO e GLÓRIA, 1999) como sendo o grau de absorção dos elementos ou compostos químicos por um organismo.

A absorção dos metais tóxicos ocorre por meio dos mecanismos de transporte da membrana celular do organismo, como pinocitose e outros. No entanto, os metais tóxicos deverão estar solúveis no meio para que o transporte celular ocorra. Portanto, o resultado negativo de testes de toxicidade, não representa, como primeira conclusão, que o efluente não seja tóxico. Vários fatores, como dureza, $\mathrm{pH}$ e temperatura, influenciam na biodisponibilidade e toxicidade da amostra (NEWMAN e JAGOE, 1992).

Vários metais tóxicos são, em ordem de magnitude, mais letais em água

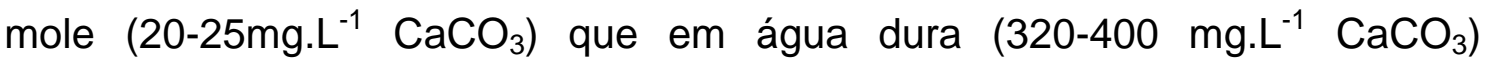
(CALAMARI et al., 1979; MAYER et al. 1992). Em geral, os metais são mais tóxicos na forma iônica que na forma de carbonato ou bicarbonato, formados pela reação com o carbonato de cálcio, presente em maior concentração em água dura (CALAMARI et al., 1979). Em relação ao pH, MAYER et al. (1992), verificaram que a diminuição do $\mathrm{pH}$ pode aumentar a toxicidade dos ácidos, mas decresce o efeito tóxico das bases, e que o aumento da temperatura da água geralmente contribui para o aumento do efeito tóxico de alguns metais.

ROUSH et al. (1985) e KLINE et al. (1987) agruparam, na forma de tabelas, diversos poluentes e sua toxicidade a diversos organismos, apresentando também, as possíveis alterações da toxicidade causadas pela 
variação de pH, temperatura, dureza da água entre outros. Fica claro, então, que todos estes fatores, associados ou não, exercem influência nas interações dos metais com o meio aquoso, tornando-os mais ou menos biodisponíveis, alterando a interpretação dos resultados dos testes de toxicidade.

Outro aspecto, que deve ser considerado, é a influência dos materiais argilosos na disponibilidade dos metais. Em estudos sobre a contaminação de metais tóxicos em solos, MATOS (1995) verificou a correlação das propriedades do solo que afetam a retenção e mobilidade de metais tóxicos no solo. Dentre elas o autor destaca o pH, capacidade de troca iônica (CTC), quantidade de matéria orgânica, quantidade e tipo de fração argila e competição iônica.

MATTIAZZO e GLORIA (1995) concluíram que, em função da concentração de metais adicionada, para solo arenoso de baixa CTC, a atividade microbiana, traduzida pela quantidade de $\mathrm{CO}_{2}$ liberado, foi significativamente afetada pela presença de metais, que ficaram disponíveis e esse efeito não foi revertido pelo aumento do valor de $\mathrm{pH}$ do solo. No solo argiloso, a presença de metais não afetou a atividade microbiana, em valores de $\mathrm{pH}$ do solo iguais ou acima de 5,0. O efeito da adição de metais foi mais prejudicial, em solos de baixa CTC e baixo conteúdo de argila, particularmente quando o valor do $\mathrm{pH}$ era 4,0, no momento da adição do metal na forma solúvel.

Fundamentando-se nestes estudos, pode-se concluir que em solos 
arenosos há uma maior propensão dos metais tóxicos serem arrastados para lençóis freáticos, ou, em se tratando de corpos d’água, contaminarem o meio aquático. O inverso pode ser observado em solos argilosos, pois, por reterem os metais tóxicos, se contaminam, mas em contrapartida, a probabilidade de contaminação do lençol freático ou de corpos d'água será diminuída. Estas informações auxiliaram a interpretação dos resultados dos testes de toxicidade e das análises químicas realizadas nos efluentes gerados pela indústria cerâmica.

Para verificar a relação da biodisponibilidade dos metais e a presença de partículas de argila, que é uma das principais matérias-primas utilizadas no processo de fabricação de placas de revestimentos cerâmicos, foram realizadas amostragens de efluentes líquidos para a realização de análises químicas. A amostragem foi realizada nos pontos onde o efluente líquido é lançado para a rede pública, ou seja, nos pontos B-4 e B-5. O ponto B-1 também foi amostrado por se tratar do efluente líquido da seção de moagem, contendo, portando, uma grande concentração de argilas. Para cada ponto coletaram-se duas amostras, sendo que em apenas uma delas foi adicionado ácido nítrico. Os resultados estão apresentados na tabela 31 . 
Tabela 31: Análise química por espectrometria de absorção atômica nos efluentes líquidos da indústria cerâmica. Amostras com ácido nítrico e sem ácido nítrico. Data de coleta 01/02/2000. Valores expressos em mg. $\mathrm{L}^{-1}$.

\begin{tabular}{|c|c|c|c|c|c|c|c|}
\hline \multirow[b]{2}{*}{ Metais } & \multicolumn{7}{|c|}{ SETORES } \\
\hline & B-1 & $\begin{array}{l}\mathrm{B}-1 \mathrm{c} / \\
\mathrm{HNO}_{3}\end{array}$ & B-4 & $\begin{array}{l}\mathrm{B}-4 \mathrm{c} / \\
\mathrm{HNO}_{3}\end{array}$ & B-5 & $\begin{array}{l}\mathrm{B}-5 \mathrm{c} / \\
\mathrm{HNO}_{3}\end{array}$ & Art. 18 \\
\hline $\mathrm{Cd}$ & n.d. & n.d. & n.d. & n.d. & n.d. & n.d. & 0,20 \\
\hline $\mathrm{Pb}$ & 0,20 & $\underline{0,25}$ & 0,06 & $\underline{0,20}$ & 0,28 & $\underline{0,80}$ & 0,50 \\
\hline $\mathrm{Zn}$ & 0,56 & $\underline{0,88}$ & 0,08 & $\underline{0,43}$ & 1,18 & $\underline{3,87}$ & \\
\hline $\mathrm{Ni}$ & 0,14 & 0,17 & 0,21 & $\overline{0,15}$ & 0,04 & 0,12 & 2,00 \\
\hline $\mathrm{Ba}$ & n.a. & $\overline{1,23}$ & 0,19 & 0,31 & n.a. & $\overline{0,39}$ & 5,00 \\
\hline $\mathrm{Ca}$ & 3,56 & 55,04 & 4,71 & $\overline{7,41}$ & 5,87 & 16,78 & \\
\hline $\mathrm{Cr}$ & 0,40 & 0,09 & 0,04 & $\underline{0,11}$ & 0,04 & $\underline{0,11}$ & 5,00 \\
\hline $\mathrm{Cu}$ & 0,13 & $\underline{0,17}$ & 0,11 & 1,38 & 0,07 & 0,06 & 1,00 \\
\hline $\mathrm{V}$ & 1,34 & $\overline{0,93}$ & 0,39 & $\overline{0,73}$ & 0,61 & 0,75 & \\
\hline Co & 0,35 & 0,24 & 0,12 & 0,15 & 0,10 & 0,10 & \\
\hline
\end{tabular}

Observando estes resultados, nota-se que há um aumento significativo dos valores das concentrações de alguns metais nas amostras conservadas com ácido nítrico em relação às mesmas amostras que não tiveram a adição do ácido, chegando, em alguns casos, a serem superiores aos limites estabelecidos pela legislação. No ponto B-1, verificou-se que $62,5 \%$ dos valores das concentrações foram mais altos na amostra conservada com ácido nítrico em relação à mesma amostra sem ácido. No ponto B-4, cerca de $89 \%$ dos resultados foram mais altos na amostra com ácido em relação à sem ácido. Para o ponto B-5, aproximadamente $67 \%$ dos valores das concentrações obtidos foram superiores nas amostras com ácido em relação à mesma 
amostra sem ácido.

Com base nestes valores, pode-se notar que a adição do ácido nítrico proporcionou a passagem dos metais, possivelmente adsorvidos pelas argilas, para o meio aquoso.

Segundo NORTON (1973) o número de íons adsorvidos sobre uma partícula de caulinita é de $3,0 \times 10^{5}$. SANTOS (1975) explicou que as argilas além de trocarem cátions em sua superfície externa, também adsorvem cátions entre as camadas estruturais, e estabeleceu a faixa usual de valores da capacidade de troca de cátions (CTC) de vários argilominerais (TAB.32).

Tabela 32: Capacidade de Troca lônica de alguns grupos de argilominerais. Em $\mathrm{pH} 7$.

\begin{tabular}{c|c}
\hline ARGILOMINERAL & $\begin{array}{c}\text { Capacidade de Troca de Cátions (CTC) } \\
\text { (meq/100g) }\end{array}$ \\
\hline Caulinita & $3-15$ \\
\hline Halosita $-2 \mathrm{H}_{2} \mathrm{O}$ & $5-10$ \\
\hline Endelita ou haloisita $-4 \mathrm{H}_{2} \mathrm{O}$ & $10-40$ \\
\hline Montmorilonita ou Esmectita & $80-150$ \\
\hline Ilita & $10-40$ \\
\hline Vermiculita & $100-150$ \\
\hline Clorita & $10-40$ \\
\hline Sepiolita-paligorsquita & $20-30$ \\
\hline
\end{tabular}

Fonte: SANTOS (1975)

A estrutura cristalina destes minerais é a grande responsável pela capacidade de troca e adsorção de cátions. Apesar de todas apresentarem estrutura cristalina em forma de lamelas ("folhas"), diferem na composição química, no arranjo cristalino e no grau de cristalinidade, afetando, portanto, a propriedade dos argilominerais de reagir química e reversivelmente com 
cátions.

GRIM (1953) apresentou três causas que influenciam a capacidade de troca de cátions dos argilominerais. A primeira causa é proveniente das ligações partidas (broken bonds) na superfície dos cristais, sendo as principais causas de capacidade de troca para minerais bem cristalizados e com baixa capacidade de troca, como no caso da ilita e, possivelmente, da caulinita. Para a montmorilonita, representa apenas $20 \%$ da capacidade de troca de cátions. A segunda causa refere-se às substituições ocorridas na estrutura da rede cristalina, do alumínio trivalente para o silício tetravalente no tetraedro, e de íons de baixa valência, particularmente o magnésio, para o alumínio trivalente do octaedro.

As argilas do grupo da caulinita apresentam baixa capacidade de troca iônica, em relação as argilas do grupo da montmorilonita, por serem melhor cristalizada, dificultando a substituição dos íons de alumínio por íons bivalentes, resultando carga negativa em sua superfície, como ocorre na montimorilonita. As ligações entre as camadas devem-se a forças fracas do tipo Van de Walls, que é a terceira causa que exerce influência na capacidade de troca de cátion dos argilomineais. Na montimorilonita, esta ligação ocorre entre íons de oxigênio, que são muito mais fracas que as ligações entre os íons de oxigênio e a hidroxila, que ocorrem na caulinita. Esta fragilidade das ligações entre as lamelas facilita a entrada espontânea de água e também de cátions que podem ser adsorvidos, concorrendo para uma grande capacidade 
de bases trocáveis na montmorilonita.

A estrutura cristalina do grupo da ilita assemelha-se ao da montmorilonita, porém com íons potássio unindo as lamelas. Mesmo fracas, a ligação dos íons de potássio são bastante fortes para causar um perfeito alinhamento de cada uma das camadas, evitando que moléculas de água penetrem com a mesma facilidade que numa montmorilonita (NORTON, 1973; SANTOS, 1975).

Para dar subsídios às interpretações dos dados obtidos, em relação a capacidade de absorção dos metais pelas argilas, supostamente presentes nos efluentes líquidos gerados pela indústria cerâmica, realizou-se, por difração de raio $\mathrm{X}$, a identificação dos grupos de argilominerais dos sólidos em suspensão presentes nos efluentes líquidos coletados nos pontos B-1 (FIG.27), B-4 (FIG.28) e B-5 (FIG.29).

No difratograma dos resíduos sólidos obtidos do ponto B-4 (FIG.28) os picos identificados referem-se ao quartzo. Neste ponto, onde se concentram os efluentes líquidos gerados no setor de biqueima, a ausência de grupos de argilominerais é devido ao fato que todas as etapas de formulação, atomização e prensagem ocorrem no setor de monoqueima, o qual abastece com as peças já conformadas o setor de biqueima. Neste setor a produção é compreendida apenas pelas etapas de queima, para obtenção do biscoito, preparação de pequenos volumes de tintas para a decoração das peças, decoração das peças, queima para fixação e estabilização das cores e, quando necessário, o 
corte das peças.

O efluente líquido deste setor é, portanto, constituído basicamente de resíduos das matérias-primas sintéticas utilizadas para a decoração das peças. Desta forma, confirmando os resultados obtidos anteriormente que, neste ponto, é mais provável encontrar os metais tóxicos disponíveis no meio aquoso, pode-se complementar que tal fato é devido a ausência ou quantidades insuficientes de argilas para adsorvê-los.

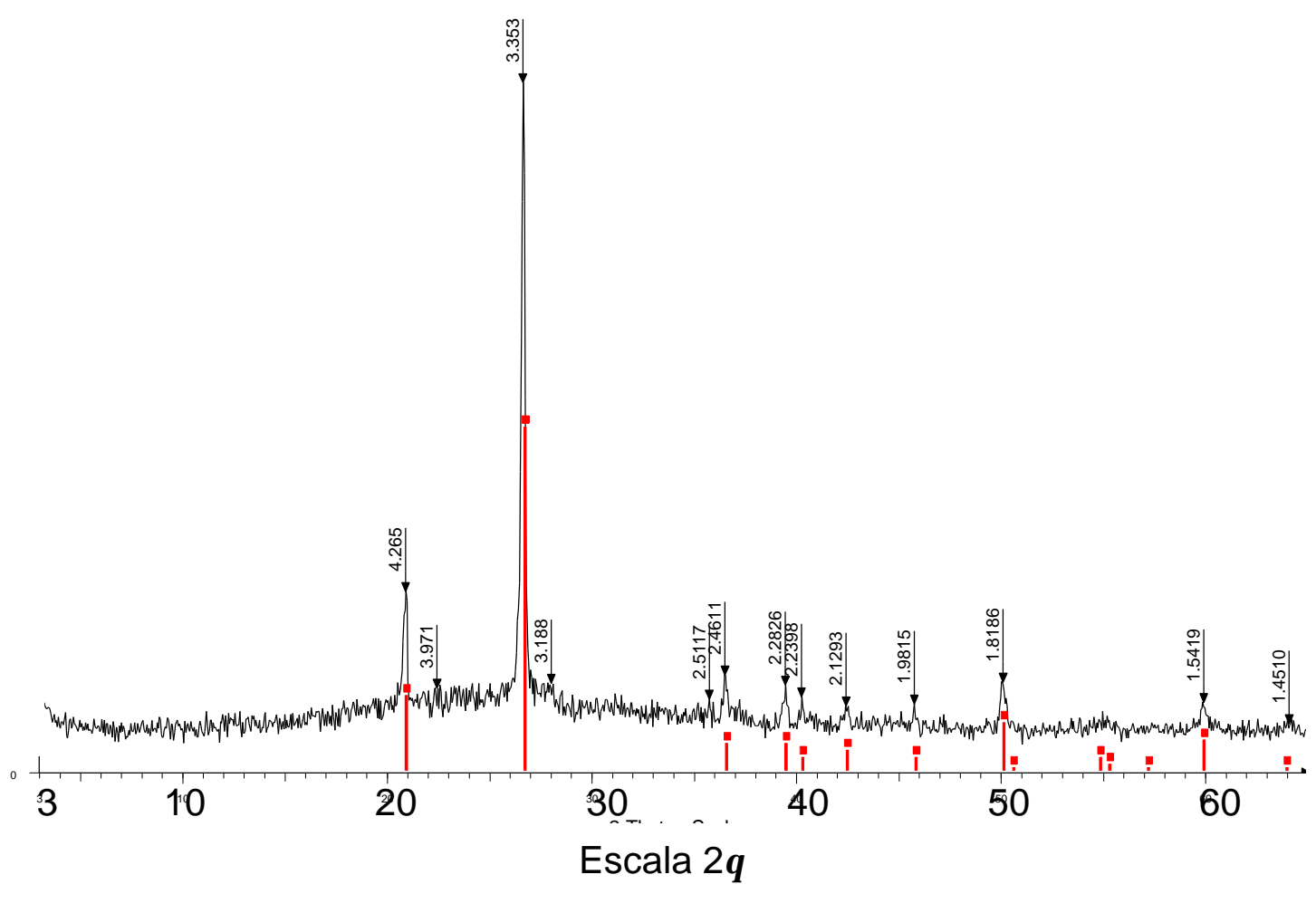

- QUARTZO

Figura 27: Difratograma realizado nos sólidos presentes no efluente líquido do ponto B-4.

Escala $2 \theta$, velocidade $2^{\circ} 2 \theta$ / minuto, iniciando em $3^{\circ} \mathrm{e}$ terminando em $65^{\circ}$, ânodo CuK $\alpha$ 
Em relação ao ponto $\mathrm{B}-5$, muitas vezes o teste de toxicidade foi negativo, mesmo apresentando concentrações de metais tóxicos acima dos limites estabelecidos pela legislação. Observando-se o difratograma desta amostra (FIG.28) verifica-se que alguns grupos de argilominerais são identificados, por exemplo o grupo da caulinita, da ilita e traços de esmectita.

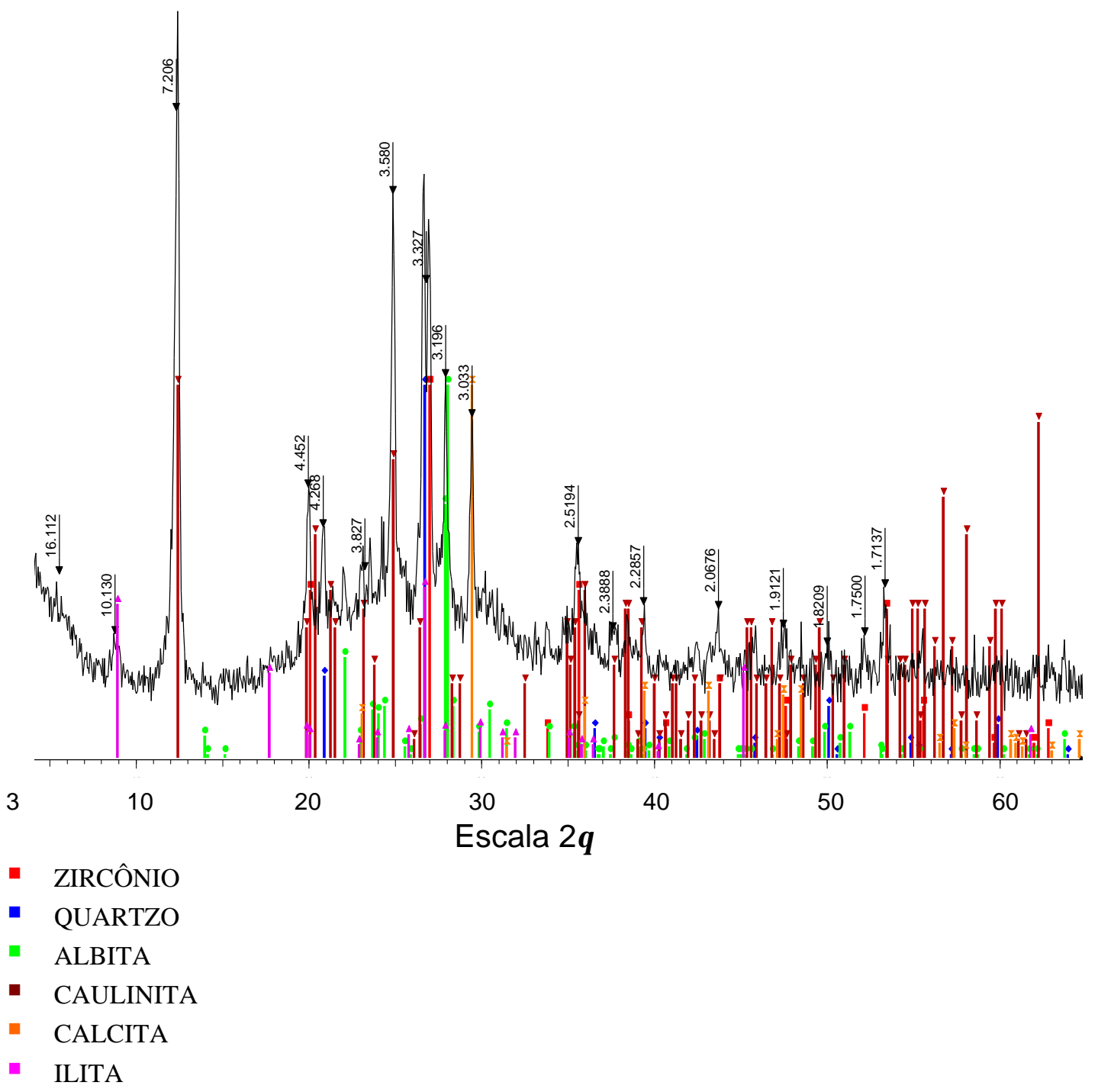

Figura 28: Difratograma realizado nos sólidos presentes no efluente líquido do ponto B-5.

Escala $2 \theta$, velocidade $2^{\circ} 2 \theta$ / minuto, iniciando em $3^{\circ}$ e terminando em $65^{\circ}$, ânodo CuK $\alpha$ 
Os resultados de difração de raio $\mathrm{X}$, obtidos a partir da amostra do ponto B-1 (FIG.29), confirmaram a presença dos grupos da caulinita, ilita e traços de esmectita, explicando a procedência destes grupos identificados no ponto B-5.

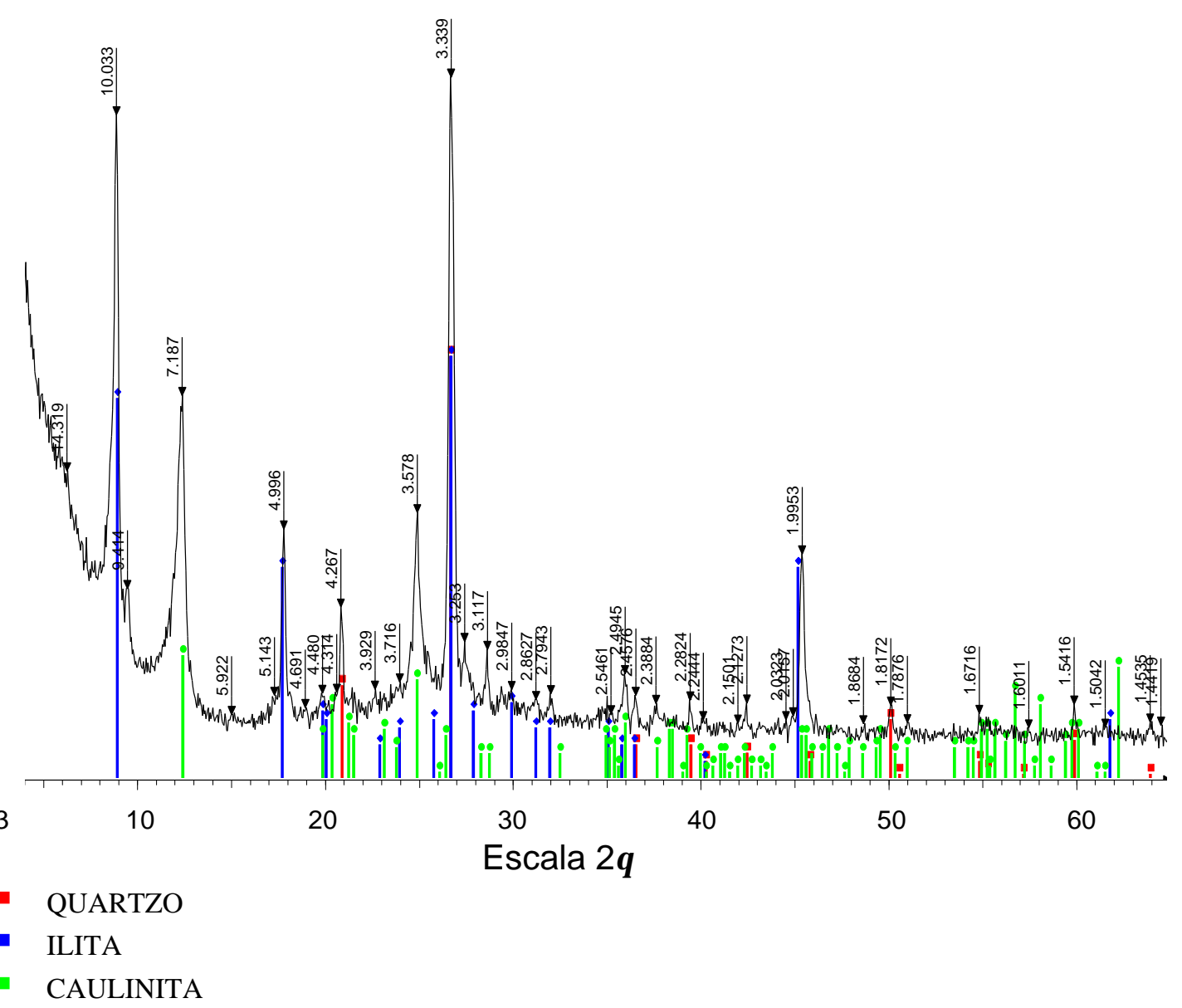

Figura 29: Difratograma realizado nos sólidos presentes no efluente líquido do ponto B-1.

Escala $2 \theta$, velocidade $2^{\circ} 2 \theta$ / minuto, iniciando em $3^{\circ}$ e terminando em $65^{\circ}$, ânodo CuK $\alpha$ 
De acordo com a capacidade de troca e de adsorção de cátions destes argilominerais, e com os estudos de contaminação dos solos citados, pode-se concluir que os metais presentes na amostra não estão biodisponíveis, pois foram adsorvidos pelas argilas presentes. Nota-se, com os dados apresentados, a importância de se realizar estudos que comprovem esta hipótese.

\section{IV.2.5. Sugestão para o Desenvolvimento de Trabalhos Futuros}

A seguir apresenta-se uma sugestão como trabalho futuro objetivando comprovar que os argilominerais contribuem para a não biodisponibilidade de metais tóxicos.

a) O primeiro passo é realizar a caracterização química do efluente líquido e identificar os argilominerais que constituem a massa cerâmica a ser utilizada.

b) A seguir, por meio da adição de uma quantidade de argilominerais para concentrações pré-determinadas de cada metal, construir uma curva de adsorção para cada metal identificado no efluente líquido,

c) A determinação das quantidades de massa cerâmica a ser adicionada pode ser obtida como segue:

i) Fazer a média das concentrações dos metais identificados no item a) e convertê-los de mg. L $^{-1}$ para meq, conforme exemplificado abaixo: 
sendo:

$$
\text { eq }=\mathbf{m} / \mathrm{MM} / \mathbf{k}
$$

onde:

$$
\mathrm{m} / \mathrm{MM}=\mathrm{mol}
$$

então:

$$
\text { eq }=\mathbf{m o l} \cdot \mathbf{k}
$$

onde:

$$
\text { k = carga do íon }
$$

ii) Somando-se os resultados de meq calculados para os metais, obtém-se o valor total meq. $\mathrm{L}^{-1}$.

d) Com a identificação dos argilominerais presentes na massa cerâmica utilizada no estudo (item a)), fazer o cálculo da média das capacidades de troca iônica para 100 gramas de massa cerâmica (TAB.32). Desta forma determina-se a quantidade de massa cerâmica para adsorver o valor total meq do efluente líquido (valor calculado no item c)).

e) A seguir, deve ser estipulado o tempo de agitação necessário para que ocorra a adsorção dos metais pela massa cerâmica.

i) Testar, em diferentes tempos, misturas contendo massa cerâmica em excesso (acima do valor determinado no item d)), para auxiliar uma maior interação entre o líquido e a massa cerâmica introduzida e garantir a total adsorção dos metais em estudo. 
ii) Para cada amostra, agitada num determinado tempo, retirar alíquotas, centrifugar, separar e reservar a porção sólida obtida,

iii) realizar análises químicas da parte líquida, seguida por uma alíquota do efluente sem adição de massa cerâmica (branco).

f) Após a determinação do tempo de agitação necessário para ocorrer a total adsorção dos metais, separar alíquotas do efluente líquido e adicionar a quantidade de massa cerâmica determinada no item d), bem como quantidades acima, abaixo deste valor.

g) Deixar estas amostras sob agitação pelo tempo determinado no item e).

h) Centrifugar as amostras e realizar análises químicas na porção líquida, seguida por uma alíquota da amostra de efluente sem adição de massa cerâmica (branco).

i) Separar uma alíquota do efluente líquido sem adição de massa cerâmica e outra alíquota do efluente líquido com a maior quantidade de massa cerâmica introduzida. Com estas amostras realizar testes de toxicidade aguda com Daphnia similis.

O estudo sugerido para a utilização de argilominerais no tratamento dos efluentes líquidos tóxicos da indústria cerâmica pode ser estendido para o tratamento de efluentes líquidos de outros processos produtivos. O resíduo sólido, proveniente deste procedimento, poderá ser reutilizado na fabricação de placas de revestimentos cerâmicos, após estudos comprovando que os metais tóxicos ficarão inertizados no próprio corpo cerâmico. 


\section{IV.2.6. Discussão dos Aspectos Ocupacionais}

Quando se realiza um levantamento dos aspectos ambientais de um empreendimento, é inevitável o confronto com aspectos ocupacionais. Para que os aspectos ocupacionais não somassem negativamente na avaliação do processo de fabricação de placas de revestimentos cerâmicos, procurou-se identificá-los, utilizando-se os dados obtidos pelo estudo da Associação Brasileira para Prevenção de Acidentes, de 1986, onde foram registradas, em cada etapa do processo produtivo de placas de revestimentos cerâmicos via úmida, os níveis de exposição dos trabalhadores para partículas inaláveis, as condições relativas a conforto térmico e ruído. As recomendações sugeridas pelo estudo acima citado, visavam a minimização da sobrecarga térmica (conforto térmico) e a redução do ruído, apresentando algumas adaptações em equipamentos da indústria, bem como a utilização de equipamentos de proteção individual. Quanto à concentração de partículas inaláveis, diversas seções foram consideradas insalubres, com valores médios de concentração acima dos limites estabelecidos pelo Ministério do Trabalho através da Portaria 3214 de 1978, anexos 1, 3 e 11 da NR-15. Na conclusão do relatório, foram sugeridas medidas para controle de geração de material particulado, como por exemplo a de evitar o uso de ar comprimido para limpeza de maquinário e de roupas, e que implementada tais medidas, a adoção de equipamentos de proteção individual (protetores respiratórios), atenderiam o objetivo de preservar a saúde dos trabalhadores destas seções. 
Atualmente, as empresas possuem diversos sistemas que minimizam a emissão de material particulado na atmosfera interna da indústria. Existem sistemas de exaustão instalados em diversas etapas que geram poeira, inclusive com a reutilização do material retido nos filtros. Na seção de decoração, a instalação de cabines, auxiliou a diminuição de dispersão do material aplicado por spray, contribuindo, inclusive para minimizar o desperdício de matéria-prima, auxiliando a reutilização.

Segundo o relatório do Departamento de Qualidade Ambiental da CETESB (1995) dos poluentes monitorados na Região Metropolitana de São Paulo, o material particulado inalável é um dos que mais se destaca, tanto pelos altos níveis de concentração quanto pelo grande número de ultrapassagens de padrão e de estado de atenção atingidos. Este poluente é composto por partículas em suspensão na atmosfera, com diâmetro aerodinâmico de corte de $10 \mu \mathrm{m}$, que penetram profundamente no aparelho respiratório. Este tipo de poluente também é o mais freqüente nas indústrias cerâmicas, independente do tipo de processo de moagem, via úmida ou via seca, devido aos tipos de matérias-primas utilizadas.

Devido a composição química das matérias-primas, naturais e sintéticas, manuseadas comumente nas indústria cerâmicas, estas partículas inaláveis podem conter metais que, dependendo da concentração, se absorvidos pelo corpo humano, podem apresentar efeitos tóxicos . 
Nas tabelas 33,34 e 35 foram correlacionados, aos elementos químicos que podem estar presentes na composição das matérias-primas naturais e sintéticas utilizadas numa indústria cerâmica, os índices biológicos toleráveis de exposição (Biologic Threshold Limit - BLT), o valor limite tolerável (Threshold Limit Value - TLV) relativo às concentrações na atmosfera, bem como as vias de absorção, os limites ocupacionais e os limites para público. Segundo QUER-BROSSA (1983) o conceito de limites aceitável de exposição (atmosférica ou biológica) deve ser entendido como o nível de exposição inferior ao risco, ou seja, risco aceitável. Porém, para serem estabelecidos critérios de aceitabilidade, deve-se ter conhecimento da relação intensidade de exposição (dose) e os efeitos na saúde. 
Tabela 33: Níveis de tolerância à exposição dos elementos químicos mais utilizados na indústria de placas de revestimentos cerâmicos

\begin{tabular}{|c|c|c|c|c|c|c|c|}
\hline \multirow{2}{*}{ ELEMENTO } & \multirow{2}{*}{$\begin{array}{c}\text { USO NA } \\
\text { INDÚSTRIA }\end{array}$} & \multirow{2}{*}{ ABSORÇÃO } & \multicolumn{3}{|c|}{ CONCENTRAÇÃO LIMITE (BTL / TLV) } & \multirow{2}{*}{$\begin{array}{c}\text { EFEITO TÓXICO } \\
\text { (CONCENTRAÇÃO) }\end{array}$} & \multirow{2}{*}{$\begin{array}{c}\text { CONCENTRAÇÃO } \\
\text { NORMAL PESSOAS } \\
\text { NÃO EXPOSTAS }\end{array}$} \\
\hline & & & SANGUE & URINA / 24H & $\mathrm{AR} / 8 \mathrm{H}$ & & \\
\hline ALUMÍNIO & $\begin{array}{c}\text { Matérias-primas } \\
\text { naturais }\end{array}$ & Via respiratória & & & $15 \mathrm{mg} \cdot \mathrm{m}^{-3}$ & & \\
\hline ANTIMÔNIO & Esmalte & Via respiratória & & $10 \mathrm{mg} \cdot \mathrm{L}^{-1}$ & $0,5 \mathrm{mg} \cdot \mathrm{m}^{-3}$ & & Urina: $<2 \mu \mathrm{g} . \mathrm{L}^{-1}$ \\
\hline ARSÊNIO & Corantes & $\begin{array}{l}\text { Via respiratória; } \\
\text { ingestão de } \\
\text { alimentos } \\
\text { contaminados } \\
\end{array}$ & & $\begin{array}{l}<750 \mu \mathrm{g} \cdot \mathrm{g}^{-1} \mathrm{de} \\
\text { creatinina }\end{array}$ & & & $\begin{array}{c}\text { Cabelo: }<3 \mathrm{ppm} \\
\text { Unhas: }<0,8 \mathrm{ppm} \\
\text { Urina: }<50 \mu \mathrm{g} \cdot \mathrm{g}^{-1} \mathrm{de} \\
\text { creatinina } \\
\end{array}$ \\
\hline BROMO & Corantes & Via respiratória & & & & & $\begin{array}{l}\text { Sangue: } 0,15- \\
1,5 \mathrm{mg} / 100 \mathrm{mg}\end{array}$ \\
\hline CÁDMIO & $\begin{array}{l}\text { Esmalte e } \\
\text { Corantes }\end{array}$ & Via respiratória & $5 \mu \mathrm{g} \cdot \mathrm{L}^{-1}$ & $\begin{array}{l}10 \mu \mathrm{g} \cdot \mathrm{g}^{-1} \mathrm{de} \\
\text { creatinina }\end{array}$ & $0,05 \mathrm{mg} \cdot \mathrm{m}^{-3}$ & & \\
\hline CHUMBO & $\begin{array}{l}\text { Corantes e } \\
\text { Vidrados }\end{array}$ & $\begin{array}{l}\text { Via respiratória, } \\
\text { ingestão de água e } \\
\text { alimentos } \\
\text { contaminados }\end{array}$ & $50 \mu \mathrm{g} / 100 \mathrm{~mL}$ & $\begin{array}{c}4 \mu \mathrm{g} / 100 \mathrm{~mL} \\
2,8 \mu \mathrm{g} / 100 \mathrm{~mL}\end{array}$ & $50 \mu \mathrm{g} \cdot \mathrm{m}^{-3}$ & $\begin{array}{l}\text { Anemia: sangue } \\
80 \mu \mathrm{g} / 100 \mathrm{~mL}\end{array}$ & Sangue: $30-40 \mu \mathrm{g} / 100 \mathrm{~mL}$ \\
\hline COBALTO & $\begin{array}{c}\text { Esmalte e } \\
\text { corantes }\end{array}$ & Via respiratória & & $<250 \mu \mathrm{g} \cdot \mathrm{L}^{-1}$ & $0,1 \mathrm{mg} \cdot \mathrm{m}^{-3}$ & & Sangue: $7,04 \mu \mathrm{g} / 100 \mathrm{~mL}$ \\
\hline COBRE & $\begin{array}{c}\text { Matérias-primas } \\
\text { naturais }\end{array}$ & $\begin{array}{l}\text { Pele, via } \\
\text { respiratória, } \\
\text { mucosas }\end{array}$ & & & $\begin{array}{c}0,2 \mathrm{mg} \cdot \mathrm{m}^{-3} \text { (pó) } \\
0,1 \mathrm{mg} \cdot \mathrm{m}^{-3} \\
\text { (fumos) }\end{array}$ & & Sangue: $2 \mu \mathrm{g} / 100 \mathrm{~mL}$ \\
\hline
\end{tabular}


Tabela 34: Níveis de tolerância à exposição dos elementos químicos mais utilizados na indústria de placas de revestimentos cerâmicos (continuação tabela 33)

\begin{tabular}{|c|c|c|c|c|c|c|c|}
\hline \multirow{2}{*}{ ELEMENTO } & \multirow{2}{*}{$\begin{array}{c}\text { USO NA } \\
\text { INDÚSTRIA }\end{array}$} & \multirow{2}{*}{ ABSORÇÃO } & \multicolumn{3}{|c|}{ CONCENTRAÇÃO LIMITE (BTL / TLV) } & \multirow{2}{*}{$\begin{array}{c}\text { EFEITO TÓXICO } \\
\text { (CONCENTRAÇÃO) }\end{array}$} & \multirow{2}{*}{$\begin{array}{c}\text { CONCENTRAÇÃO } \\
\text { NORMAL PESSOAS } \\
\text { NÃO EXPOSTAS }\end{array}$} \\
\hline & & & SANGUE & URINA / 24H & $\mathrm{AR} / 8 \mathrm{H}$ & & \\
\hline CRÔMIO & $\begin{array}{c}\text { Matérias-primas } \\
\text { naturais e } \\
\text { Corantes }\end{array}$ & $\begin{array}{l}\text { Via respiratória e } \\
\text { cutâneo-mucoso }\end{array}$ & & $\begin{array}{l}20 \mu \mathrm{g} \cdot \mathrm{g}^{-1} \mathrm{de} \\
\text { creatinina }\end{array}$ & $\begin{array}{l}0,05 \mathrm{mg} \cdot \mathrm{m}^{-3(5)} \\
0,001 \mathrm{mg} \cdot \mathrm{m}^{-3(6)}\end{array}$ & & $\begin{array}{c}\text { Soro: } 0,3-3,2 \mu \mathrm{g} \cdot \mathrm{L}^{-1} \\
\text { Urina: } \\
<3,5 \mu \mathrm{g} \cdot \mathrm{g}^{-1} \mathrm{de} \\
\text { creatinina }\end{array}$ \\
\hline FLÚOR & $\begin{array}{c}\text { Matérias-primas } \\
\text { naturais }\end{array}$ & Via respiratória & & & & $\begin{array}{c}\text { Absorção (efeitos } \\
\text { cumulativos): }>2 \mathrm{mg} / \text { dia e } \\
\text { deposita-se como cálcio } \\
(\mathrm{Ca}) \text { e fósforo }(\mathrm{P})\end{array}$ & $\begin{array}{l}\text { Ossos: } 100-200 \mathrm{mg} / 100 \mathrm{~g} \\
\text { Sangue: } 0,2-0,8 \mathrm{mg} \cdot \mathrm{L}^{-1} \\
\text { Urina: } 0,5-2 \mathrm{mg} \cdot \mathrm{L}^{-1}\end{array}$ \\
\hline MAGNÉSIO & $\begin{array}{c}\text { Matérias-primas } \\
\text { naturais }\end{array}$ & Via respiratória & & & $0,7 \mathrm{mg} \cdot \mathrm{m}^{-3}$ & & Sangue: $1,92 \mathrm{mg} / 100 \mathrm{~mL}$ \\
\hline MANGANÊS & $\begin{array}{c}\text { Matérias-primas } \\
\text { naturais }\end{array}$ & Via respiratória & $75 \mu \mathrm{g} \cdot \mathrm{L}^{-1}$ & & $50 \mathrm{mg} \cdot \mathrm{m}^{-3}$ (pó) & & $\begin{array}{c}\text { Fezes: } 5 \text { ppm } \\
\text { Soro: } 5-12 \mu \mathrm{g} . \mathrm{L}^{-1}\end{array}$ \\
\hline NÍQUEL & $\begin{array}{c}\text { Matérias-primas } \\
\text { naturais e } \\
\text { Esmaltes } \\
\end{array}$ & Via respiratória & & $\begin{array}{l}100 \mu \mathrm{g} / \mathrm{g} \text { de } \\
\text { creatinina }\end{array}$ & & & $\begin{array}{l}\text { Soro: } 5 \mu \mathrm{g} . \mathrm{L}^{-1} \\
\text { Urina: } 10 \mu \mathrm{g} / \mathrm{g} \text { de } \\
\text { creatinina }\end{array}$ \\
\hline SELÊNIO & Corantes & $\begin{array}{c}\text { Via respiratória e } \\
\text { cutânea }\end{array}$ & & $\begin{array}{l}100 \mu \mathrm{g} / \mathrm{g} \mathrm{de} \\
\text { creatinina }\end{array}$ & & $\begin{array}{l}\text { Absorção: } 0,2 \mathrm{mg} \cdot \mathrm{L}^{-1} \\
\text { Urina: } 0,5 \mathrm{mg} \cdot \mathrm{L}^{-1}(7)\end{array}$ & Urina: $0,01-0,15 \mathrm{mg} \cdot \mathrm{L}^{-1}$ \\
\hline
\end{tabular}

${ }^{5} \mathrm{Cr}$ VI

${ }^{6}$ National Institute Occupational Safety Health

${ }^{7}$ Grave intoxicação 
Tabela 35: Níveis de tolerância à exposição dos elementos químicos mais utilizados na indústria de placas de revestimentos cerâmicos (continuação das tabelas 33 e 34)

\begin{tabular}{|c|c|c|c|c|c|c|c|}
\hline \multirow{2}{*}{ ELEMENTO } & \multirow{2}{*}{$\begin{array}{c}\text { USO NA } \\
\text { INDÚSTRIA }\end{array}$} & \multirow{2}{*}{ ABSORÇÃO } & \multicolumn{3}{|c|}{ CONCENTRAÇÃO LIMITE (BTL / TLV) } & \multirow{2}{*}{$\begin{array}{c}\text { EFEITO TÓXICO } \\
\text { (CONCENTRAÇÃO) }\end{array}$} & \multirow{2}{*}{$\begin{array}{c}\text { CONCENTRAÇÃO } \\
\text { NORMAL PESSOAS } \\
\text { NÃO EXPOSTAS }\end{array}$} \\
\hline & & & SANGUE & URINA / 24H & $\mathrm{AR} / 8 \mathrm{H}$ & & \\
\hline VANÁDIO & Corantes & Via respiratória & & $\begin{array}{l}25 \mu \mathrm{g} / \mathrm{g} \text { de } \\
\text { creatinina }\end{array}$ & $\begin{array}{c}0,5 \mathrm{mg} \cdot \mathrm{m}^{-3} \text { (pó) } \\
0,05 \mathrm{mg} \cdot \mathrm{m}^{-3} \\
\text { (fumos) }\end{array}$ & & $\begin{array}{l}\text { Soro: } 0-1,2 \mu \mathrm{g} . \mathrm{L}^{-1} \\
\text { Urina: }<10 \mu \mathrm{g} / \mathrm{g} \mathrm{de} \\
\text { creatinina }\end{array}$ \\
\hline ZINCO & $\begin{array}{l}\text { Matérias-primas } \\
\text { naturais e } \\
\text { Corantes }\end{array}$ & Via respiratória & Soro: $2 \mathrm{mg} . \mathrm{L}^{-1}$ & $700 \mu \mathrm{g}$ & & & $\begin{array}{c}\text { Soro: } 0,56-1,41 \mathrm{mg} . \mathrm{L}^{-1} \\
\text { Urina: } 75-200 \mu \mathrm{g} / 24 \\
\text { horas }\end{array}$ \\
\hline ZIRCÔNIO & $\begin{array}{l}\text { Matérias-primas } \\
\text { naturais e } \\
\text { Corantes }\end{array}$ & Via respiratória & & & & Acúmulo nos tecidos & Soro: $1-3 \mu \mathrm{g} / \mathrm{g}^{(8)}$ \\
\hline
\end{tabular}


MARTINS (1996) realizou um estudo no Município de Santa Gertrudes, no qual caracterizou alguns elementos na poeira total em suspensão na atmosfera. Os dados obtidos foram comparados com dados da estação telemétrica do Parque Dom Pedro II, região central da cidade de São Paulo (FIG.30).

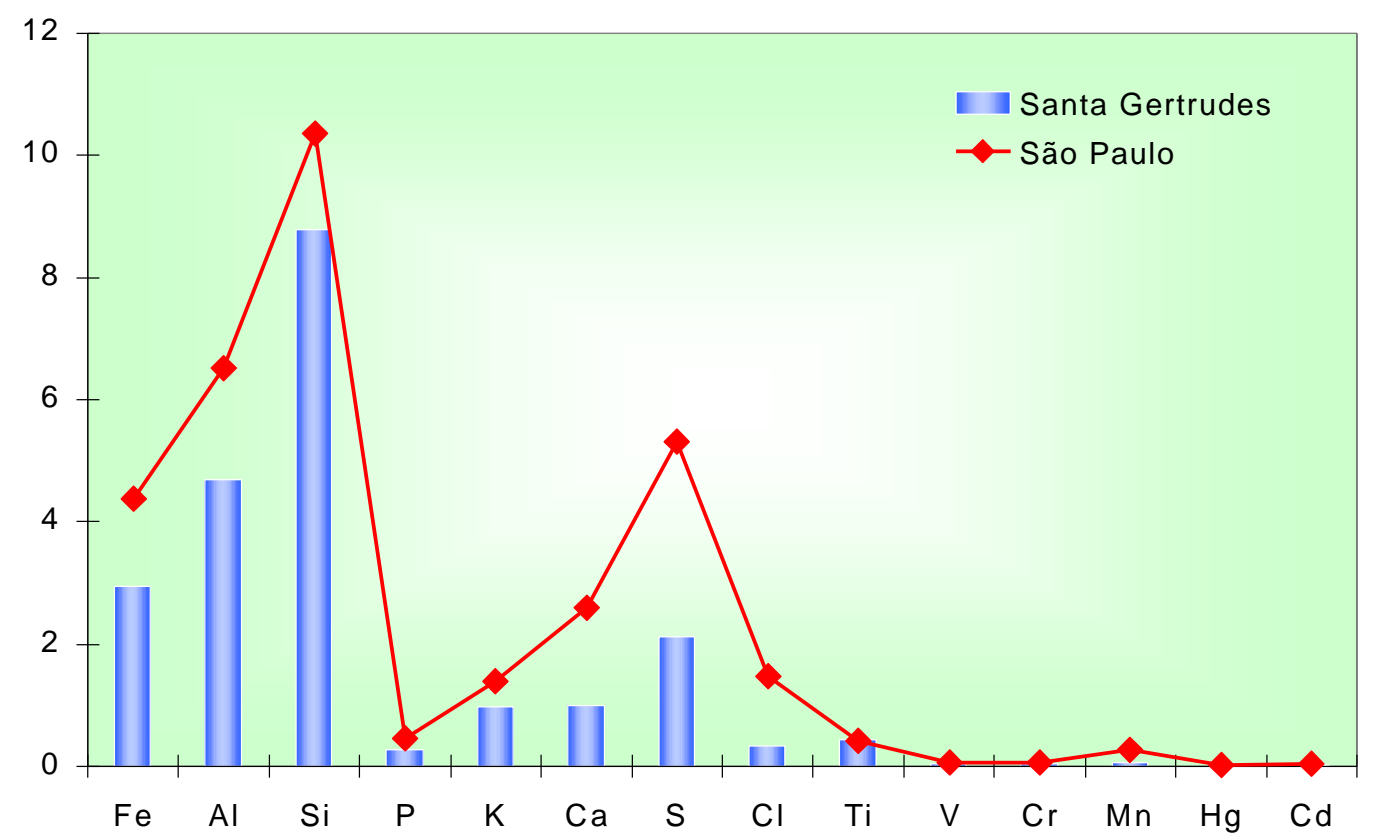

Figura 30: Comparação das caracterizações de alguns elementos presentes na poeira total em suspensão na atmosfera do Município de Santa Gertrudes e do Parque Dom Pedro / São Paulo Fonte: MARTINS, 1996

O Município de Santa Gertrudes apresenta uma grande concentração de indústrias de placas de revestimentos cerâmicos, predominantemente com processo via seca, as quais emitem maior quantidade de particulados do que as indústrias de placas de revestimentos cerâmicos com processo via úmida. Os valores encontrados na cidade de São Paulo foram, consideravelmente, maiores dos que os encontrados no Município de Santa Gertrudes. 
Seguindo a metodologia usada pela CETESB, comparou-se os dados de monitoramento para partículas inaláveis da estação telemétrica do Parque Dom Pedro II com a estação telemétrica de Diadema, região industrial da Grande São Paulo caracterizada pelo grande número e diversidade de tipos de indústrias, incluindo indústria de placas de revestimentos cerâmicos.

No monitoramento realizado pela CETESB, entre 1994 a 1998, foi verificado que, ao longo destes anos, a maioria das estações ultrapassaram o padrão anual de qualidade do ar para partículas inaláveis $\left(50 \mu \mathrm{g} / \mathrm{m}^{3}\right)$. A estação de Diadema ultrapassou, aproximadamente, 10 vezes este padrão, sendo que a estação do Parque Dom Pedro II ultrapassou, em média, aproximadamente, 18 vezes os padrões de qualidade do ar. Em 1994, a estação do Parque Dom Pedro II atingiu quatro vezes os níveis de atenção, enquanto a estação de Diadema, em nenhum momento, nos cinco anos de monitoramento, atingiu 0 nível de atenção. Pela porcentagem do tempo em que o padrão diário $\left(150 \mu \mathrm{g} / \mathrm{m}^{3}\right)$ foi ultrapassado em 1998 , a estação telemétrica de Diadema continua abaixo da estação do Parque Dom Pedro II. Ainda em 1998, a qualidade do ar, para partículas inaláveis, foi inadequada na estação do Parque Dom Pedro II, sendo que o mesmo não ocorreu com a estação de Diadema (ALONSO, 1999).

Assim sendo, pode-se concluir que os problemas causados pelas emissões atmosféricas geradas por indústrias cerâmicas sejam, principalmente, de ordem ocupacional, tendo de ser solucionado no âmbito da 
empresa, não extravasando para o meio ambiente a ponto de se constituir um problema ambiental, se considerada uma região com diversos tipos de indústria e tráfego urbano intenso. 


\section{CAPÍTULO V}

\section{ADEQUAÇÃO AMBIENTAL}

\section{V.1. SUGESTÕES PARA ADEQUAÇÃO AMBIENTAL PARA INDÚSTRIA DE REVESTIMENTO CERÂMICO}

1. Preparação da formulação de massa do corpo cerâmico (Ponto B-1)

- Instalação de um sistema de contenção e remoção do óleo proveniente do bombeamento da barbotina para o atomizador, antes de ser lançado ao tanque de decantação dos efluentes líquidos da preparação da massa do corpo cerâmico;

- Identificar a causa das elevadas concentrações de cálcio, identificadas tanto nos efluentes líquidos como nos resíduos sólidos deste ponto.

\section{Preparação de Tintas e Vidrados (Ponto B-2)}

- Monitoramento periódico dos efluentes líquidos e resíduos sólidos gerados;

- Articular, junto aos fabricantes das matérias-primas sintéticas, a mudança na formulação destes insumos, substituindo o chumbo e/ou outros metais tóxicos, por elementos menos agressivos; 
- Treinamento dos funcionários, encarregados na preparação e aplicação dos insumos de decoração, objetivando diminuir as perdas destes materiais.

- Disposição separada dos resíduos, otimizando o tratamento, e a eventual recuperação destes materiais.

- Identificar a causa das elevadas concentrações de zinco e cálcio, identificadas tanto nos efluentes líquidos como nos resíduos sólidos deste ponto.

\section{Linha de decoração - Setor de Monoqueima (Ponto B-3)}

- Monitoramento periódico dos efluentes líquidos e resíduos sólidos gerados;

- Articular, junto aos fabricantes das matérias-primas sintéticas, a mudança na formulação destes insumos, substituindo o chumbo e/ou outros metais tóxicos, por elementos menos agressivos;

- Identificar a causa das elevadas concentrações de zinco e cálcio, identificadas tanto nos efluentes líquidos como nos resíduos sólidos deste ponto.

\section{Setor de Biqueima (Ponto B-4)}

- Instalação de tanques de decantação, para retenção do resíduo sólido;

- Estudos para a reutilização destes resíduos decantados;

- Tratamento químico do efluente líquido para redução da concentração dos metais tóxicos, principalmente o cádmio e o chumbo;

- Monitoramento periódico dos efluentes líquidos e resíduos sólidos gerados; 
- Articular, junto ao fabricante, a mudança na formulação das matérias-primas sintéticas, substituindo o chumbo e/ou outros metais tóxicos, por elementos menos agressivos;

- Treinamento dos funcionários, encarregados na preparação e aplicação dos insumos de decoração, objetivando diminuir as perdas destes materiais.

- Identificar a causa das elevadas concentrações de zinco e cálcio, identificadas tanto nos efluentes líquidos como nos resíduos sólidos deste ponto.

\section{Caixa de captacão e liberação para rede pública dos efluentes líquidos} (Ponto B-5)

- Monitoramento periódico do efluente líquido;

- Identificar a causa das elevadas concentrações de zinco e cálcio, identificadas tanto nos efluentes líquidos como nos resíduos sólidos deste ponto.

\section{6. Água de Abastecimento (Ponto B-6)}

- Identificar a causa das elevadas concentrações de zinco e cálcio presentes na água de abastecimento.

- Verificar as condições de limpeza dos reservatórios e, se for o caso, realizar manutenção em menores intervalos de tempo.

- Informar que esta água é imprópria para o consumo humano.

- Instalar válvulas tipo gatilho nas mangueiras. 


\section{Laboratório de Controle de Qualidade (Ponto B-7)}

- Instalação de um tanque de contenção para o efluente líquido;

- Monitoramento periódico do efluente líquido;

- Tratamento químico do efluente líquido para redução da concentração dos metais tóxicos, principalmente o chumbo, quando aplicável;

- Mudança dos insumos utilizados, principalmente daqueles que contém chumbo em sua composição;

- Identificar a causa das elevadas concentrações de zinco e cálcio, identificadas nos efluentes líquidos deste ponto.

\section{Linha de decoração - Setor de Biqueima (Ponto B-8)}

- Monitoramento periódico do efluente líquido;

- Identificar a causa das elevadas concentrações de zinco e cálcio, identificadas nos efluentes líquidos deste ponto. 


\section{CAPÍTULO VI}

\section{CONCLUSÕES}

1. A Matriz de Avaliação Ambiental permitiu a identificação e hierarquização dos pontos de geração de efluentes e resíduos (rápida, simples e de baixo custo).

2. Com a comparação das matrizes, antes e após medidas corretivas, permite a verificação da eficiência das ações e o acompanhamento do desempenho ambiental da indústria.

3. Com as devidas adequações, a matriz pode ser utilizada para qualquer processo produtivo.

4. O controle da composição das matérias-primas naturais permite prever a qualidade do produto final.

5. As matérias-primas sintéticas são fonte de metais tóxicos.

6. Efluente líquido do Setor de Biqueima (B-4), deverá ser tratado prioritariamente (metais tóxicos biodisponíveis).

7. Pontos B-3 e B-5, presença de argilominerais diminuiu a biodisponibilidade dos metais tóxicos.

8. A variação do $\mathrm{pH}$ poderá tornar biodisponíveis os metais adsorvidos pelas argilas. 


\section{APÊNDICE 1}

PLANILHAS DAS NORMAS DA ABNT PERTINENTES

AOS ASPECTOS AMBIENTAIS DAS ETAPAS DO

PROCESSO DE PRODUÇÃO VIA ÚMIDA DAS

INDÚSTRIAS DE PLACAS DE REVESTIMENTOS

CERÂMICOS 
Tabela 36: Planilha de detalhamento dos aspectos ambientais e processos tecnológicos - Normas - ABNT das atividades da etapa de preparação da massa do corpo cerâmico, monoqueima (continuação - TAB 4).

(Fonte: BRAGA, et al. 1996 - adaptado)

\begin{tabular}{|c|c|c|c|c|}
\hline \multirow{4}{*}{$\underbrace{\begin{array}{c}\text { Processo de } \\
\text { Fabricação }\end{array}}_{\begin{array}{c}\text { Tipo de } \\
\text { Resíduo gerado }\end{array}}$} & \multicolumn{4}{|c|}{ 1. MONOQUEIMA } \\
\hline & \multicolumn{4}{|c|}{ 1.1 SETOR DE PREPARAÇÃO DA MASSA DO CORPO DO REVESTIMENTO CERÂMICO } \\
\hline & 1.1 .6 & 1.1 .7 & 1.1 .8 & 1.1 .9 \\
\hline & tanque de barbotina & atomizador - "Spray Drying" & gerador de gás quente & silo de massa \\
\hline \multicolumn{5}{|l|}{ SÓLIDOS } \\
\hline \multirow{9}{*}{ LÍQUIDOS } & NBR 9800 & & & \\
\hline & NBR 9897 & & & \\
\hline & NBR 9898 & & & \\
\hline & NBR 10561 & & & \\
\hline & NBR 10664 & & & \\
\hline & NBR 12988 & & & \\
\hline & NBR 13035 & & & \\
\hline & NBR 13042 & & & \\
\hline & NBR 13403 & & & \\
\hline \multirow{4}{*}{ PARTÍCULAS SUSPENSÃO } & & NBR 9547 & \multirow{2}{*}{ NBR 10736} & NBR 9547 \\
\hline & & NBR 10736 & & NBR 10736 \\
\hline & & NBR12065 & \multirow{2}{*}{ NBR 12085} & NBR12065 \\
\hline & & NBR 12085 & & NBR 12085 \\
\hline \multirow{4}{*}{ GASES DE EXAUSTÃO } & & NBR 9546 & NBR 9546 & \\
\hline & & NBR 10700 & NBR 10700 & \\
\hline & & NBR 12979 & NBR 12979 & \\
\hline & & NBR 13157 & NBR 13157 & \\
\hline PEÇAS QUEBRADAS & & & & \\
\hline
\end{tabular}


Tabela 37: Planilha de detalhamento dos aspectos ambientais e processos tecnológicos - Normas - ABNT das atividades da etapa de preparação da massa do corpo cerâmico, monoqueima (continuação).

(Fonte: BRAGA, et al. 1996 - adaptado)

\begin{tabular}{|c|c|c|c|c|c|}
\hline \multirow{4}{*}{\begin{tabular}{c}
\multicolumn{2}{c}{$\begin{array}{c}\text { Processo de } \\
\text { Fabricação }\end{array}$} \\
$\begin{array}{c}\text { Tipo de } \\
\text { Resíduo gerado }\end{array}$
\end{tabular}} & \multicolumn{5}{|c|}{ 1. MONOQUEIMA } \\
\hline & \multirow[b]{2}{*}{1.1 .10} & DR DE PREPARAÇĀO DA & ASSA DO CORPO D & VESTIMENTO CER & ÂMICO \\
\hline & & \multirow{2}{*}{\begin{tabular}{|l|}
1.1 .11 \\
compactação - peças
\end{tabular}} & \multirow{2}{*}{$\begin{array}{ll}1.1 .12 & \\
& \text { esteira }\end{array}$} & \multirow{2}{*}{$\begin{array}{l}1.1 .13 \\
\text { estufas de secagen }\end{array}$} & \multirow{2}{*}{\begin{tabular}{|l|}
1.1 .14 \\
esteira
\end{tabular}} \\
\hline & \begin{tabular}{|l} 
esteira \\
\end{tabular} & & & & \\
\hline \multicolumn{6}{|l|}{ SÓLIDOS } \\
\hline \multicolumn{6}{|l|}{ LÍQUIDOS } \\
\hline \multirow{4}{*}{ PARTÍCULAS SUSPENSÃO } & NBR 9547 & NBR 9547 & NBR 9547 & NBR 9547 & NBR 9547 \\
\hline & NBR 10736 & NBR 10736 & NBR 10736 & NBR 10736 & NBR 10736 \\
\hline & NBR12065 & NBR12065 & NBR12065 & NBR12065 & NBR1206 \\
\hline & NBR 12085 & NBR 12085 & NBR 12085 & NBR 12085 & NBR 12085 \\
\hline \multirow{3}{*}{ GASES DE EXAUSTÃO } & & & & NBR 9546 & \\
\hline & & & & $\frac{\text { NBR } 10 / 00}{\text { NBR 12979 }}$ & \\
\hline & & & & NBR 13157 & \\
\hline PEÇAS QUEBRADAS & & NBR 11174 & & NBR 11174 & \\
\hline
\end{tabular}


Tabela 38: Planilha de detalhamento dos aspectos ambientais e processos tecnológicos - Normas - ABNT das atividades da etapa de preparação da massa de decoração do revestimento cerâmico, monoqueima.

(Fonte: BRAGA, et al. 1996 - adaptado)

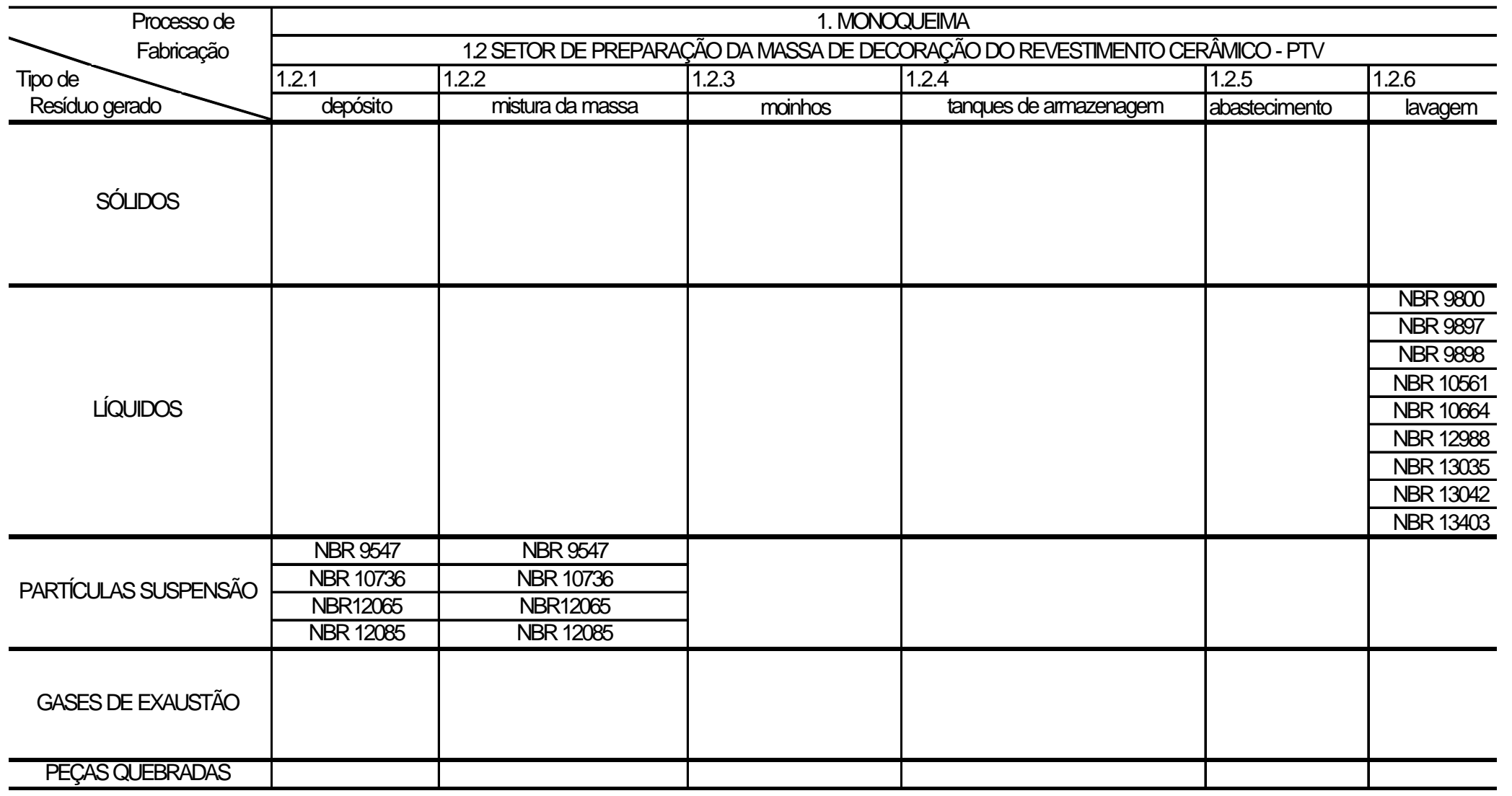


Tabela 39: Planilha de detalhamento dos aspectos ambientais e processos tecnológicos - Normas - ABNT das atividades da etapa de decoração do revestimento cerâmico, monoqueima.

(Fonte: BRAGA, et al. 1996 - adaptado)

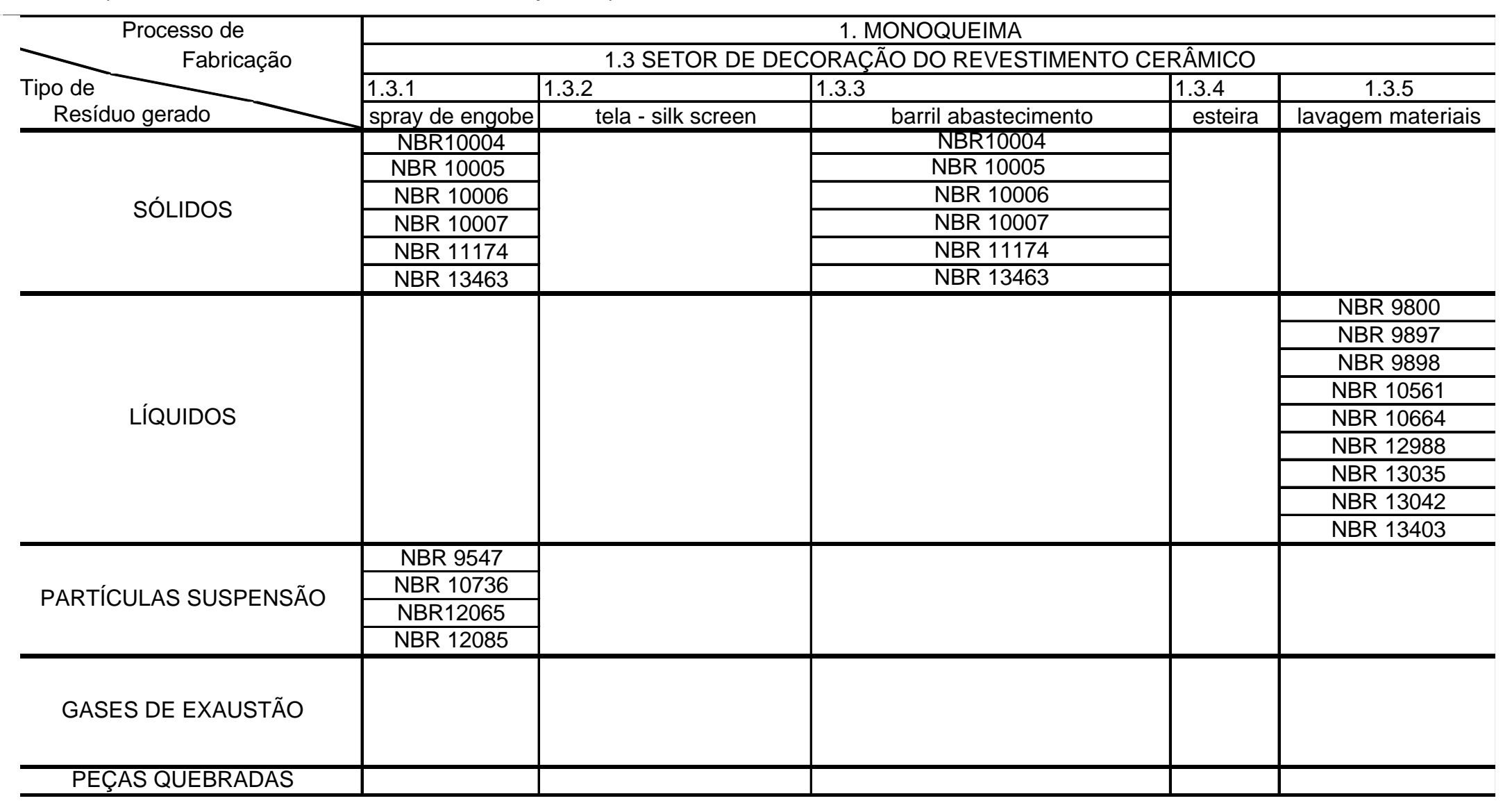


Tabela 40: Planilha de detalhamento dos aspectos ambientais e processos tecnológicos - Normas - ABNT das atividades da etapa de queima e seleção do revestimento cerâmico, monoqueima.

(Fonte: BRAGA, et al. 1996 - adaptado)

\begin{tabular}{|c|c|c|c|c|}
\hline \multirow{4}{*}{$\begin{array}{c}\begin{array}{c}\text { Processo de } \\
\text { Fabricação }\end{array} \\
\begin{array}{c}\text { Tipo de } \\
\text { Resíduo gerado }\end{array} \\
\end{array}$} & \multicolumn{4}{|c|}{ 1. MONOQUEIMA } \\
\hline & \multicolumn{4}{|c|}{ 1.4 SETOR DE QUEIMA E SELEÇÃO DO REVESTIMENTO CERÂMICO } \\
\hline & 1.4 .1 & 1.4 .2 & 1.4 .3 & 1.4 .4 \\
\hline & fornos a rolo & empilhamento peças & seleção das peças & embalagem \\
\hline \multicolumn{5}{|l|}{ SÓLIDOS } \\
\hline \multicolumn{5}{|l|}{ LÍQUIDOS } \\
\hline \multirow{4}{*}{ PARTÍCULAS SUSPENSÃO } & & NBR 9547 & NBR 9547 & NBR 9547 \\
\hline & & NBR 10736 & NBR 10736 & NBR 10736 \\
\hline & & NBR12065 & NBR12065 & NBR12065 \\
\hline & & NBR 12085 & NBR 12085 & NBR 12085 \\
\hline \multirow{4}{*}{ GASES DE EXAUSTÃO } & NBR 9546 & & & \\
\hline & NBR 10700 & & & \\
\hline & NBR12979 & & & \\
\hline & NBR 13157 & & & \\
\hline PEÇAS QUEBRADAS & NBR 11174 & NBR 11174 & NBR 11174 & NBR 11174 \\
\hline
\end{tabular}


Tabela 41: Planilha de detalhamento dos aspectos ambientais e processos tecnológicos - Normas - ABNT das atividades da etapa de preparação da massa do revestimento cerâmico / Biscoito, biqueima.

(Fonte: BRAGA, et al. 1996 - adaptado)

\begin{tabular}{|c|c|c|c|c|c|}
\hline \multirow{4}{*}{$\begin{array}{c}\begin{array}{c}\text { Processo de } \\
\text { Fabricação }\end{array} \\
\begin{array}{c}\text { Tipo de } \\
\text { Resíduo gerado }\end{array}\end{array}$} & \multicolumn{5}{|c|}{ 2. BIQUEIMA } \\
\hline & \multicolumn{5}{|c|}{ 2.1 SETOR DE PREPARAÇÃO DA MASSA DO REVESTIMENTO CERÂMICO / BISCOITO } \\
\hline & 2.1 .1 & 2.1 .2 & 2.1 .3 & 2.1 .4 & 2.1 .5 \\
\hline & depósito & formulação da massa & moagem & compactação - peças & sforno - primeira queima / biscoi \\
\hline \multirow{6}{*}{ SÓLIDOS } & NBR10004 & NBR10004 & & & \\
\hline & NBR 10005 & NBR 10005 & & & \\
\hline & NBR 10006 & NBR 10006 & & & \\
\hline & NBR 10007 & NBR 10007 & & & \\
\hline & NBR 11174 & NBR 11174 & & & \\
\hline & NBR 13463 & NBR 13463 & & & \\
\hline \multirow{9}{*}{ LÍQUIDOS } & & & NBR 9800 & & \\
\hline & & & NBR 9897 & & \\
\hline & & & NBR 9898 & & \\
\hline & & & NBR 10561 & & \\
\hline & & & NBR 10664 & & \\
\hline & & & NBR 12988 & & \\
\hline & & & NBR 13035 & & \\
\hline & & & NBR 13042 & & \\
\hline & & & NBR 13403 & & \\
\hline \multirow{4}{*}{ PARTÍCULAS SUSPENSÃO } & NBR 9547 & NBR 9547 & & NBR 9547 & \\
\hline & NBR 10736 & NBR 10736 & & NBR 10736 & \\
\hline & NBR12065 & NBR12065 & & NBR12065 & \\
\hline & NBR 12085 & NBR 12085 & & NBR 12085 & \\
\hline \multirow{4}{*}{ GASES DE EXAUSTÃO } & & & & & NBR 9546 \\
\hline & & & & & NBR 10700 \\
\hline & & & & & NBR 12979 \\
\hline & & & & & NBR 13157 \\
\hline PEÇAS QUEBRADAS & & & & NBR 11174 & NBR 11174 \\
\hline
\end{tabular}


Tabela 42: Planilha de detalhamento dos aspectos ambientais e processos tecnológicos - Normas - ABNT das atividades da etapa de preparação da massa de decoração do biscoito, biqueima.

(Fonte: BRAGA, et al. 1996 - adaptado)

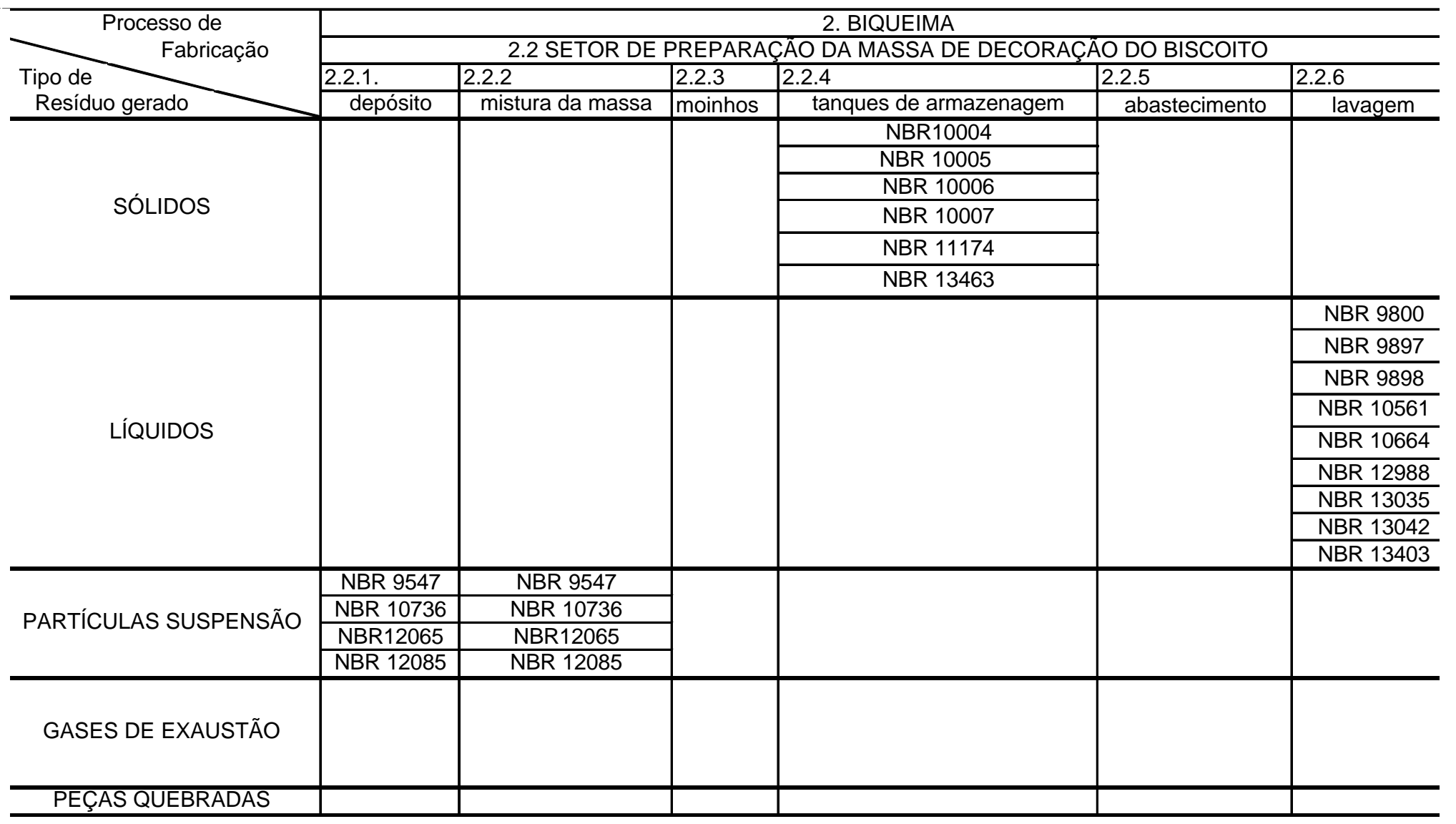


Tabela 43: Planilha de detalhamento dos aspectos ambientais e processos tecnológicos - Normas - ABNT das atividades da etapa de decoração do biscoito, biqueima.

(Fonte: BRAGA, et al. 1996 - adaptado)

\begin{tabular}{|c|c|c|c|c|}
\hline \multirow{4}{*}{$\begin{array}{r}\begin{array}{r}\text { Processo de } \\
\text { Fabricação } \\
\text { Tipo de } \\
\text { Resíduo gerado }\end{array} \\
\end{array}$} & \multicolumn{4}{|c|}{$\begin{array}{c}\text { 2. BIQUEIMA } \\
2.3 \text { SETOR DE DECORACÂAO DO BISCOITO }\end{array}$} \\
\hline & \multicolumn{4}{|c|}{ 2.3 SETOR DE DECORAÇÃO DO BISCOITO } \\
\hline & 2.3 .1 & 2.3 .2 & 2.3 .3 & 2.3 .4 \\
\hline & decoração manual & aplicação filete ouro & lavagem de materiais & forno - segunda queima \\
\hline \multirow{6}{*}{ SÓLIDOS } & NBR10004 & NBR10004 & & \\
\hline & NBR 10005 & NBR 10005 & & \\
\hline & NBR 10006 & NBR 10006 & & \\
\hline & NBR 10007 & NBR 10007 & & \\
\hline & NBR 11174 & NBR 11174 & & \\
\hline & NBR 13463 & NBR 13463 & & \\
\hline \multirow{9}{*}{ LÍQUIDOS } & & & NBR 9800 & \\
\hline & & & NBR 9897 & \\
\hline & & & NBR 9898 & \\
\hline & & & NBR 10561 & \\
\hline & & & NBR 10664 & \\
\hline & & & NBR 12988 & \\
\hline & & & NBR 13035 & \\
\hline & & & NBR 13042 & \\
\hline & & & NBR 13403 & \\
\hline \multirow{4}{*}{ PARTÍCULAS SUSPENSÃO } & NBR 9547 & NBR 9547 & & NBR 9547 \\
\hline & NBR 10736 & NBR 10736 & & NBR 10736 \\
\hline & NBR12065 & NBR12065 & & NBR12065 \\
\hline & NBR 12085 & NBR 12085 & & NBR 12085 \\
\hline \multirow{4}{*}{ GASES DE EXAUSTÃO } & & & & NBR 9546 \\
\hline & & & & NBR 10700 \\
\hline & & & & NBR12979 \\
\hline & & & & NBR 13157 \\
\hline PEÇAS QUEBRADAS & NBR 11174 & NBR 11174 & & NBR 11174 \\
\hline
\end{tabular}


Tabela 44: Planilha de detalhamento dos aspectos ambientais e processos tecnológicos - Normas - ABNT das atividades da etapa de embalagem, seleção e estoque das peças cerâmicas, biqueima.

(Fonte: BRAGA, et al. 1996 - adaptado)

\begin{tabular}{|c|c|c|c|}
\hline Fabricação & \multicolumn{3}{|c|}{ 2.4 SETOR DE SELEÇĀO, EMBALAGEM E ESTOQUE DAS PEÇAS CERȦMICAS } \\
\hline Tipo de & 2.4 .1 & 2.4 .2 & 2.4 .3 \\
\hline Resíduo gerado & bancada - seleção das peças & embalagem das peças & estocagem das peças \\
\hline \multicolumn{4}{|l|}{ SÓLIDOS } \\
\hline \multicolumn{4}{|l|}{ LÍQUIDOS } \\
\hline \multirow{4}{*}{ PARTÍCULAS SUSPENSÃO } & & & NBR 9547 \\
\hline & & & NBR 10736 \\
\hline & & & NBR12065 \\
\hline & & & NBR 12085 \\
\hline \multicolumn{4}{|l|}{ GASES DE EXAUSTÃO } \\
\hline PEÇAS QUEBRADAS & $\overline{N B R} 11174$ & NBR 11174 & NBR 11174 \\
\hline
\end{tabular}




\section{APÊNDICE 2}

EXEMPLO DE REGISTRO DE DADOS DA ÁGUA DE DILUIÇÃO PARA OS TESTES DE TOXICIDADE AGUDA REALIZADOS NOS EFLUENTES LÍQUIDOS DESTE ESTUDO. 
Tabela 45 Registro de dados da água de diluição para os testes de toxicidade aguda com Daphnia similis.

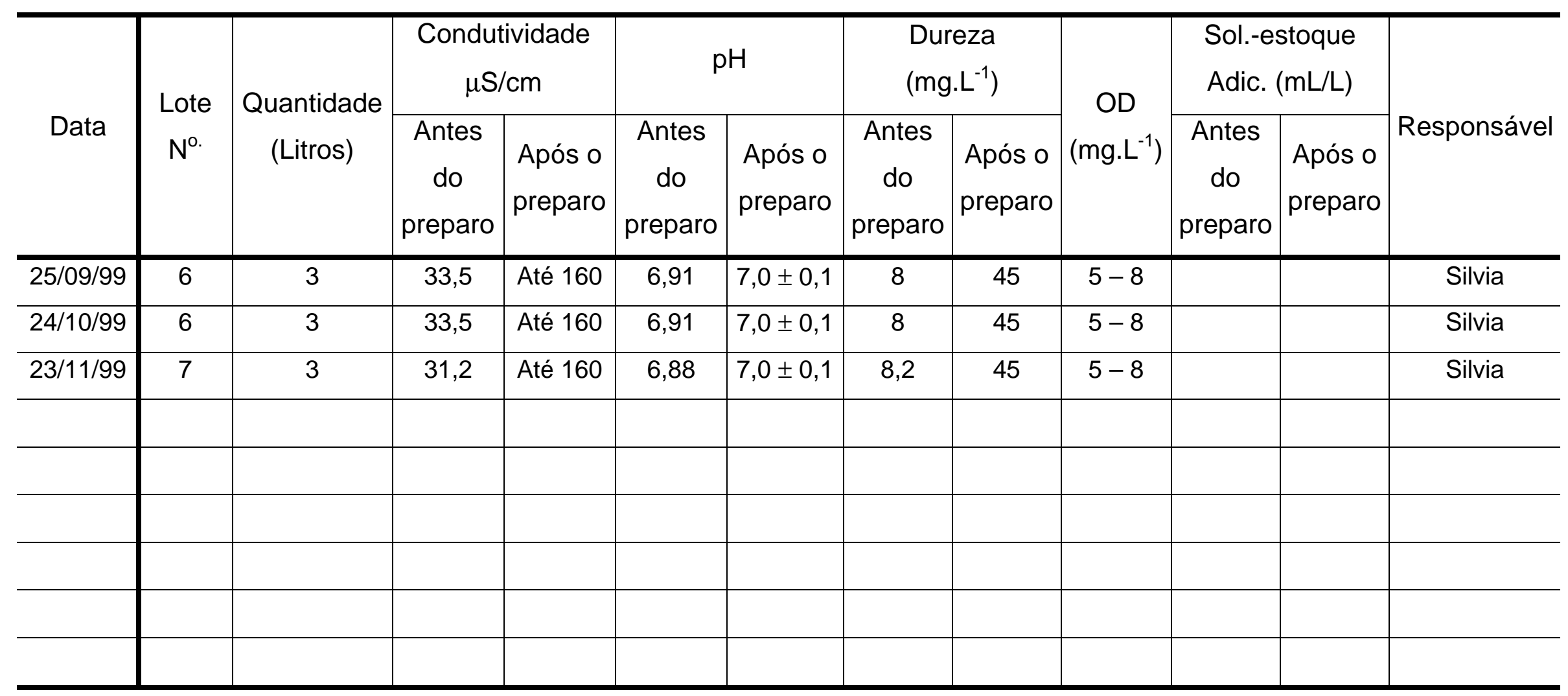




\section{REFERÊNCIAS BIBLIOGRÁFICAS}

AGUDO, E.G. (Coord.). Guia de coleta e preservação de amostras de água. São Paulo, SP: CETESB, 1987.

ALBARO J.L.A. Glazes for ceramic wall and floor tiles: evolution and perspectives. Tile and Brick Int., v. 9, n. 5, p. 273 - 278, 1993.

ALMEIDA, L.T. Política ambiental: Uma análise econômica. Campinas, SP: Papirus, Fundação Editora UNESP, 1998.

ALONSO, C.D. (Coord.) Relatório de qualidade do ar no Estado de São Paulo. São Paulo, SP: CETESB, 1999 (Série Relatórios).

ALVES, F.E. (Org.) Gerenciamento ambiental na indústria. In: SIMPÓSIO NACIONAL DE GERENCIAMENTO AMBIENTAL NA INDÚSTRIA, $3^{\circ}$, 1993, São Paulo. Anais... São Paulo, SP: Signus, 1993.

AMARANTE Jr., A. Vidrados cerâmicos. São Paulo Centro Nacional de Tecnologia SENAI, Mario Amato. Núcleo da Cerâmica, 1995, v. 1/2.

ASSOCIAÇÃO BRASILEIRA DE NORMAS TÉCNICAS. Agentes químicos no ar - Coleta de aerodispersóides por filtração - Método de ensaio. 1995. (ABNT NBR 12085). 
ASSOCIAÇÃO BRASILEIRA DE NORMAS TÉCNICAS. Água - Determinação de resíduos (sólidos) - Método Gravimétrico. 1995. (ABNT NBR 10664).

ASSOCIAÇÃO BRASILEIRA DE NORMAS TÉCNICAS. Águas Determinação de resíduo sedimentável (sólidos sedimentáveis) Método do Cone Imhoff. 1995. (ABNT NBR 10561).

ASSOCIAÇÃO BRASILEIRA DE NORMAS TÉCNICAS. Amostragem de resíduos - Procedimento. 1995. (ABNT NBR 10007)

ASSOCIAÇÃO BRASILEIRA DE NORMAS TÉCNICAS. Armazenamento de resíduos classe II (não inertes) e III (inertes) - Procedimento. 1995. (ABNT NBR 11174).

ASSOCIAÇÃO BRASILEIRA DE NORMAS TÉCNICAS. Atmosfera Determinação da Taxa de poeira sedimentável total - Método de ensaio. 1995. (ABNT NBR 12065).

ASSOCIAÇÃO BRASILEIRA DE NORMAS TÉCNICAS. Atmosfera Determinação da concentração de dióxido de enxofre pelo método do peróxido de hidrogênio - Método de ensaio. 1995. (ABNT NBR 12979).

ASSOCIAÇÃO BRASILEIRA DE NORMAS TÉCNICAS. Caracterização de Cargas poluidoras em efluentes líquidos industriais e domésticos Procedimento. 1995. (ABNT NBR 13042). 
ASSOCIAÇÃO BRASILEIRA DE NORMAS TÉCNICAS. Coleta de resíduos sólidos - Classificação. 1995. (ABNT NBR 13463).

ASSOCIAÇÃO BRASILEIRA DE NORMAS TÉCNICAS. Critérios para lançamento de efluentes líquidos industriais no sistema coletor público de esgotos sanitários. 1995. (ABNT NBR 9800).

ASSOCIAÇÃO BRASILEIRA DE NORMAS TÉCNICAS. Líquidos livres Verificação em amostras de resíduos - Método de ensaio. 1995. (ABNT NBR 12988).

ASSOCIAÇÃO BRASILEIRA DE NORMAS TÉCNICAS. Lixiviação de resíduos - Procedimento. 1995. (ABNT NBR 10005).

ASSOCIAÇÃO BRASILEIRA DE NORMAS TÉCNICAS. Material particulado em suspensão na atmosfera - determinação da concentração de fumaça pelo Método de refletância da luz - Método de ensaio. 1995. (ABNT NBR 10736).

ASSOCIAÇÃO BRASILEIRA DE NORMAS TÉCNICAS. Medição de vazão em efluentes líquidos e corpos receptores - escoamento livre Procedimento. 1995. (ABNT NBR 13403).

ASSOCIAÇÃO BRASILEIRA DE NORMAS TÉCNICAS. Método de referência para a determinação de partículas em suspensão na atmosfera (método amostrador de grandes volumes). 1995. (ABNT NBR 9547). 
ASSOCIAÇÃO BRASILEIRA DE NORMAS TÉCNICAS. Método referência para determinação de dióxido de enxofre na atmosfera. 1995. (ABNT NBR 9546).

ASSOCIAÇÃO BRASILEIRA DE NORMAS TÉCNICAS. Método referência para a determinação contínua de monóxido de carbono na atmosfera (espectrometria na região infra-vermelho do espectro). 1995. (ABNT NBR 13157).

ASSOCIAÇÃO BRASILEIRA DE NORMAS TÉCNICAS. Planejamento de amostragem em dutos e chaminés de fontes estacionárias Procedimentos. 1995. (ABNT NBR 10700).

ASSOCIAÇÃO BRASILEIRA DE NORMAS TÉCNICAS. Planejamento de amostragem de efluentes líquidos e corpos receptores Procedimento. 1995. (ABNT NBR 9897).

ASSOCIAÇÃO BRASILEIRA DE NORMAS TÉCNICAS. Planejamento e instalação de laboratórios para análises e controle de águas Procedimento. 1995. (ABNT NBR 13035).

ASSOCIAÇÃO BRASILEIRA DE NORMAS TÉCNICAS. Preservação e Técnicas de amostragem de efluentes líquidos e corpos receptores Procedimento. 1995. (ABNT NBR 9898). 
ASSOCIAÇÃO BRASILEIRA DE NORMAS TÉCNICAS. Resíduos sólidos Classificação. 1995. (ABNT NBR 10004).

ASSOCIAÇÃO BRASILEIRA DE NORMAS TÉCNICAS. Solubilização de resíduos - Procedimento. 1995. (ABNT NBR 10006).

ASSOCIAÇÃO NACIONAL DOS FABRICANTES DE CERÂMICA PARA REVESTIMENTO - ANFACER, [publicação anual], São Paulo, SP: 2000.

BARBA, A.; FELIU, C.; GARCIA, J.; GINÉS, F.; SÁNCHEZ, E.; SANZ, V. Materias-primas para la fabricación de soportes de baldosas cerâmicas. Castellón: Instituto de Tecnología Cerámica - AICE, 1997. p 15 -33 .

BARBIERI, J.C. Comércio internacional e meio ambiente: reflexões para a rodada do milênio. In: ENCONTRO NACIONAL SOBRE GESTÃO EMPRESARIAL E MEIO AMBIENTE, 5º, nov.17-19, 1999, São Paulo. Anais... São Paulo, SP: Plêiade 1999. p. 37 - 49.

BASSI, C. Smaltare il supporto inertizzato: Ceramiche Marazzi. Ceramic Word Review, n. 6, 1993.

BASSOI, J.L.; et al. Implementação de testes de toxidade no controle de efluentes líquidos. São Paulo, SP: CETESB, 1990 (Série Manuais). 
BLASCO A.; ESCARDINO, A.; BUSANI, G.; MONFORT, E.; AMORÓS, J.L.; ENRIQUE, J.; BELTRÁN, V.; NEGRE, P. Tratamiento de emisiones gaseosas efluentes líquidos y residuos sólidos de la industria cerámica. Castellón: Instituto de Tecnologia Ceramica, Universitat Jaime I, Associacion de Investigacion de las Industrias Cerâmicas - AICE. 1997. p. 1-191.

BRAGA, T.O.; FORNASARI FILHO, N.; BATISTUCCI, S.G.G.; MONTANHESI, M. O.R.; COSTA, V.L.C.; ALUANI,S.S.; PAMPLONA, R.I. Auditoria ambietnal: uma proposta para empreendimentos mineiros. São Paulo: Instituto de Pesquisas Tecnológicas, 1996 (Publicação IPT; 2451).

BRASIL. Lei $n^{0} 6938$, de 31 de agosto de 1981. Dispõe sobre a Política Nacional do Meio Ambiente, seus fins e mecanismos de formulação e aplicação (com redação dada pelas Leis n ${ }^{0}$ 7804, de 18 de julho de 1989 e 8028, de 12 de abril de 1990) e dá outras providências. Art. $2^{\circ}$; Art. $4^{\circ}$, vii; Art. 14, iv, 1‥ Diário Oficial [da] União, 02 set. 1981.

BRASIL. Resolução CONAMA n ${ }^{\circ} 20$, de 18 de junho de 1986. Classifica águas doces, salobras e salinas do Território Nacional em nove classes, segundo seus usos preponderantes (Esta resolução revogou as Portarias MINTER $n^{\circ} 0013$, de 15/01/76, e 536, de 07/12/76). 
BRASIL. Resolução CONAMA n 3, de 28 de junho de 1990a. Estabelece os Padrões de Qualidade do Ar (Publicada no D.O U. de 16/08/90, pág. 15.518).

BRASIL. Resolução CONAMA n 5, de 05 de agosto de 1993. Dispõe sobre a destinação final de Resíduos Sólidos. Define normas mínimas para tratamento de resíduos sólidos oriundos de serviços de saúde, portos e aeroportos. Estende exigências aos terminais rodoviários e ferroviários. Define: Resíduos Sólidos, Plano de Gerenciamento, Sistema de Tratamento, Sistema de Disposição Final. Classificação de resíduos GRUPO A - Presença de agentes biológicos; GRUPO B - Características químicas; GRUPO C - Rejeitos radioativos; GRUPO D - Resíduos comuns que não se enquadrem nos demais grupos.

BRASIL. Resolução CONAMA nº 8, de 06 de dezembro de 1990b. Estabelece limites máximos de emissão de poluentes do ar para processos de combustão externa em fontes novas fixas como: caldeiras, geradores de vapor, centrais para a geração de energia elétrica, fornos, fornalhas, estufas e secadores para geração e uso de energia térmica, incineradores e gaseificadores.

BURZACCHINI, B. Technical developmentes and trends in ceramic glazes. Tile \& Brick Int. v. 7, n. 1, p. 9 - 14, 1991. 
BUSANI, G.; CREMONINI, F.; MAZZALI, P.; MEDICI, C.; PALMONARI, C.; TENAGLIA, A.; TIMELLINI, G.; TORREGGIANI, A. Piastrelle ceramiche e ambiente - emissioni gassose, acque, fanghi, rumore. Sassuolo: p. 1 419, 1995.

CALAMARI, D.; MARCHETTI, R.; VAILATI, G. Influence of water hardness on cadmium toxicity to Salmo gairdneri Rich. Water Res.. v. 14, p. 1421-1426, 1979.

COELHO, J.M. A importância das matérias-primas minerais na competitividade de segmentos cerâmicos. Campinas, SP: 1996. Dissertação (Mestrado) - Univ. Estadual de Campinas.

COMPANHIA DE TECNOLOGIA DE SANEAMENTO AMBIENTAL Comportamento sazonal da poluição do ar em São Paulo - Análise de 14 anos de dados da RMSP e Cubatão 1981 a 1994. São Paulo, SP: 1995.

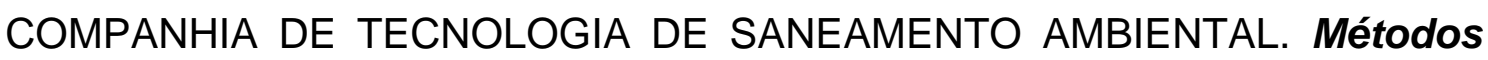
de avaliação da toxicidade de poluentes a organismos aquáticos. São Paulo, SP: 1997. v. 1-3.

CORSON, W.H. Manual global de ecologia: 0 que você pode fazer a respeito da crise do meio ambiente. 2. ed. São Paulo, SP: Augustus, 1996. p. $41-64$. 
DERISIO J.C. Introdução ao controle de poluição ambiental. São Paulo, SP: CETESB, 1992.

DONAIRE, D. Gestão ambiental na empresa. São Paulo, SP: Atlas, 1995. p. $13-27$

ESCARDINO, A.; SANCHEZ, E.; MORENO, A.; GIMENEZ, S. Used catalyst as an additive in ceramic glazes. Tile \& Brick Int., v. 9, n. 5, p. $279-281$, 1993.

FERRARI, K.R.; FIGUEIREDO FILHO, P.M. de; PASCHOAL, J.O.A. Impacto ambiental em indústria de placas cerâmicas. In: ENCONTRO NACIONAL SOBRE GESTÃO EMPRESARIAL E MEIO AMBIENTE, 5, nov. 17-19, 1999, São Paulo. Anais... São Paulo, SP: Plêiade, 1999. p. 505 - 517.

FIGUEIREDO FILHO, P.M. de; FERRARI K.R.; ARIOLI, E.E.; MÔNACO, O.A.; ALMEIDA, E.B. de; TOMI, G.F.C. de; BAUMGARTNER, J.B. TAUKTORNISIELO, S.M.; RISOLA, S.W.; BICCA, V.H.F. Relatório do Grupo Avaliação Ambiental. In: PASCHOAL, J.O.A. (coord.) - Projeto Plataforma para Indústria Brasileira de Revestimento Cerâmico - relatório final [São Paulo, SP]: Centro Cerâmico do Brasil, 1999a.

FIGUEIREDO FILHO, P.M. de; FERRARI, K.R.; PASCHOAL, J.O.A. O setor de revestimento cerâmico e o meio ambiente. In: ENCONTRO NACIONAL SOBRE GESTÃO EMPRESARIAL E MEIO AMBIENTE, 5, nov. 17-19, 1999, São Paulo. Anais... São Paulo, SP: Plêiade, 1999b. p 493 - 504 
FIGUEIREDO FILHO, P.M.; DE TOMI, G.; FERRARI, K.R. Diagnosis and proposal of actions to overcome environmetal problems in mining of raw materials used by brazilian ceramic tiles industries. In: INTERNATIONAL GEOLOGICAL CONGRESS, $31^{\text {ST }}$, Ago., 2000, Rio de Janeiro. Anais... Rio de Janeiro, RJ, 2000.

GESTÃO Ambiental - Compromisso da Empresa. Gazeta Mercantil, São Paulo, abr. 1996. Fascículos 1 - 8.

GOLDSTEIN, G.E.; et al. Procedimentos para utilização de testes de toxicidade no controle de efluentes líquidos. São Paulo, SP: CETESB, 1990. (Série Manuais).

GORINI, A.P.F.; CORREA, A.R. Cerâmica para revestimentos. In: BNDES setorial, n. 10, p. 201-252, 1999.

GREGO, M.I.B.M. Estudo dos efeitos da aditivação de argilas com tortas de filtração para produzir blocos de vedação. Rio Claro, SP: 1998. Dissertação (Mestrado) Univ. Estadual Paulista.

GRIM, R.E. Clay mineralogy. New York, NY: McGraw-Hill, 1953.

GUSMÃO, R.P.; MAIO, R.C.; CARREIRA, M.E.P.C.; ESTEVES, M.G.; BRANCO, M.L.G.C.; AMENLA, P.L. Diagnóstico Brasil - A ocupação do território e o meio ambiente. Rio de Janeiro, RJ: IBGE, 1990. 
HEMENWAY, C.G.; GILDERSLEEVE, J.P. ISO 14000 - O que é?. São Paulo, SP: IMAM, 1995.

$\mathrm{KIRSCH}, \mathrm{H}$. Mineralogia aplicada: para engenheiros, tecnólogos e estudantes. São Paulo, SP: Polígono, Ed. USP, 1972.

KLINE, E.R.; MATTSON, V.R.; PICKERING, Q.H.; SPEHAR, D.L.; STEPHAN, C.E. Effects of pollution on freshwater organisms - fate and effects of pollutants. J. WPCF, v. 59, n. 6, p. 539-572, 1987.

LIPIETZ, A. Audácia - O impasse do liberal. São Paulo, SP: Nobel, 1994. Cap. 4 e 5.

MACKENZIE, R.C. The differential thermal investigation of clays. London: Mineralogical Society, 1957.

MAKARON, O.M.S.M. Análise e avaliação de riscos - conceitos básicos. São Paulo - Apostila da Universidade Paulista: Análise de Riscos, 1997. p. $1-29$

MARIANO, W.A; JORGE Jr., A.M.; PRIETO, M.A.M.L. Técnica de preparação de amostras para MEV. In: SIMPÓSIO BRASILEIRO DE MICROSCOPIA ELETRÔNICA E TÉCNICAS ASSOCIADAS À PESQUISA DE MATERIAIS - MICROMAT-94, 4 , out. 26-28, 1994, São Carlos. Anais... São Carlos: SP, SBME, 1994. p. $515-518$. 
MARINO, L.F.B. Estudo da expansividade de revestimentos cerâmicos porosos segundo composição mineralógica, pressão de compactação e temperatura de queima. São Carlos, SP, 1997. Dissertação (Mestrado) Univ. Federal de São Carlos.

MARTINS, M.H.R.B. Avaliação de alguns elementos na Poeira Total em Suspensão na Atmosfera do Município de Santa Gertrudes - CETESB, São Paulo. - Setor de amostragem e Análise do Ar - Relatório interno, pp. 1-4, Outubro 1996.

MATOS, A.T. Fatores de retardamento e coeficientes de dispersão dos metais zinco, cádmio, cobre e chumbo em solos do município de Viçosa - MG. Viçosa, MG, 1995. Tese (Doutoramento) - Univ. Federal de Viçosa. In: Estabelecimento de valores de referência de qualidade e de intervenção para solos e águas subterrâneas no Estado de São Paulo - Relatório Final - CETESB - Setor de Qualidade de Solos e Águas Subterrâneas, Dezembro 1999, p20-22. 
MATTIAZZO, M.E.; GLÓRIA, N.A. Parâmetros para adição a solos de resíduos contendo metais. In: Estudos com soluções. In: CONGRESSO BRASILEIRO DE CIÊNCIAS DO SOLO. 25, Viçosa, MG, julho 23-29, 1995. Resumos expandidos... Viçosa: SBCS, 1995. p.2315-2317. In: Estabelecimento de valores de referência de qualidade e de intervenção para solos e águas subterrâneas no Estado de São Paulo - Relatório Final - CETESB - Setor de Qualidade de Solos e Águas Subterrâneas, Dezembro 1999, p20-22.

MAYER Jr., F.L.; MARKING, L.L.; BILLS, T.D.; HOWE, G.E. Physicochemical factors affecting toxicity. In FRESHWATER: HARDNESS, $\mathrm{pH}$, AND TEMPERATURE. In: BIOAVAILABILITY PHYSICAL, CHEMICAL, AND BIOLOGICAL INTERACTIONS. August 17-22,1992, Pelleston, Michigan Proceedings of the Therteenth Pellston Workshop, 1992, p. 5-22.

MENDES, S.P.; PRACIDELLI, S.; SANTOS, L.M.N.; COUTINHO Jr., T.A. Tecnologia cerâmica - processo de fabricação de revestimentos. Centro Nacional de Tecnologia SENAI, Mario Amato, Núcleo da Cerâmica, 1995. 
MORAES, S.A; CARVALHO, L.H.; RAMOS, S.M.L.S. Efeito da modificação superficial da bentonita nas propriedades morfológicas de compósitos de polipropileno / bentonita. In: SIMPÓSIO BRASILEIRO DE MICROSCOPIA ELETRÔNICA E TÉCNICAS ASSOCIADAS À PESQUISA DE MATERIAIS - MICROMAT-94, 4º out. 26-28, 1994, São Carlos. Anais... São Carlos: SP, SBME, 1994. p. $609-610$.

MORIN, E; KERN A.B. Terra pátria - A agonia planetária. Portugal: Instituto Piaget, 1993. Cap. 3.

MOURA, L.A.A. Qualidade e gestão ambiental: sugestões para implantação das normas ISO 14.000 nas empresas. São Paulo, SP: Oliveira Mendes, 1998, p.79-99.

NEWMAN, M.C.; JAGOE, C.H. Ligands and the bioavailability of metals in aquatic environments. In: FRESHWATER: HARDNESS, PH, AND TEMPERATURE. IN: BIOAVAILABILITY PHYSICAL, CHEMICAL, AND BIOLOGICAL INTERACTIONS, August 17-22,1992 Pelleston, Michigan Proceedings of the Therteenth Pellston workshop, p. 39-61.

NORTON, F.H. Introdução à tecnologia cerâmica. São Paulo, SP: USP, 1973.

NUNES, J.A. Tratamento físico-químico de efluentes industriais Aracaju: 1993. 
OLIVEIRA, H.A. Estudo para reaproveitamento do resíduo lama de cal do processo KRAFT de fabricação de celulose e papel em cerâmicas de revestimento. São Paulo: 2000. Dissertação (Mestrado) - Instituto de Pesquisas Energéticas e Nucleares

PASCHOAL J.O.A.; PASQUALINI, D.A.; VASCONCELLOS, E. Competitividade e inovação tecnológica - Um estudo do setor de revestimento cerâmico. Projeto apresentado à Faculdade de Economia, Administração e Contabilidade da Universidade de São Paulo para conclusão do curso MBA Executivo Internacional - São Paulo, 1997.

PASCHOAL, J. O. A. (coord.) Projeto Plataforma para Indústria Brasileira de Revestimento Cerâmico - relatório final [São Paulo, SP.]: Centro Cerâmico do Brasil, 1999.

PLANTENBERG, C.M.; AB'SABER, A.N. (Orgs.) Previsão de impactos: Estudo de impacto ambiental no leste, oeste e sul. Experiências no Brasil, na Rússia e na Alemanha. São Paulo, SP: USP, 1994.

QUER-BROSSA, S. Toxicologia industrial. Barcelona, Espanha: Salvat, 1983.

REPETTO, R. Relações de complementaridade entre livre comércio e política ambiental. In: Comércio e meio ambiente: Direito, economia e política. São Paulo, SP: Secretaria de Estado do Meio Ambiente, 1996, p. 49 - 53. 
RIBEIRO, H.S. Poluição do ar e doenças respiratórias em crianças da grande São Paulo: Um estudo de geografia médica. São Paulo, 1988. Tese (Doutoramento), Univ.de São Paulo.

RIPOLI FILHO, F.A. A utilização de rejeito industrial cerâmico-chamote- como fator de qualidade na fabricação de elementos cerâmicos: um estudo experimental. Cerâmica. n.281/282, Mai/Jun/Jul/Ago, 1997. p 133-39.

ROUSH, T.H.; PHIPPS, G.L.; SPEHAR, D.L.; STEPHAN, C.E.; PICKERING, Q.H. Effects of pollution on freshwater organisms - Fate and effects of pollutants. J. WPCF, v. 57, n. 6, p. 667-699, 1985.

SANTOS, L.M.N. Tecnologia cerâmica - vidrados - classificação. Centro Nacional de Tecnologia SENAI, Mario Amato, Núcleo da Cerâmica, 1995.

SANTOS, P.S. Tecnologia de Argilas, Aplicada às Argilas Brasileiras. São Paulo, SP: USP, 1975, v.1-2, p.45-55, p. 242 - 273, p. 393 - 405, p. 468 500.

SÃO PAULO (Estado). Decreto $\mathrm{n}^{0}$ 8.468, Anexo 6, de 08 de setembro de1976a. Dispõe sobre os padrões de emissão para material particulado Padrão de Emissão (PE) a que se refere o Art. 33-A, acrescentado pelo Art. $6^{\circ}$ do Decreto $n^{0} 15.425$ de $23 / 07 / 80$. 
SÃO PAULO (Estado). Decreto $n^{\circ} 8.468$, Anexo 8, de 08 de setembro de 1976b. Dispõe sobre os padrões de emissão para material particulado a que se refere o Art. 33-B, acrescentado pelo Art. $3^{\circ}$ do Decreto $n^{0} 18.386$ de $22 / 01 / 82$.

SÃO PAULO (Estado). Decreto ${ }^{\circ} 8.468$, Art. $7^{\circ}$, de 08 de setembro de 1976c. Classifica os corpos d'água receptores do território do Estado, em quatro classes.

SÃO PAULO (Estado). Decreto $n^{0} 8.468$, Seção II, Art. $18^{\circ}$, de 08 de setembro de 1976d. Dispõe sobre os padrões de emissão de efluentes líquidos de qualquer fonte poluidora.

SÃO PAULO (Estado). Decreto $n^{0.8 .468}$, Art. 51; 52; 53; 55; 56, de 08 de setembro de 1976e. Dispõem sobre a poluição do solo, disposição final, acumulação temporária e tratamento de resíduos de qualquer natureza.

SÃO PAULO (Estado). Lei $\mathrm{n}^{0} \cdot 997$, de 31 de maio de 1976f. Dispõe sobre o controle da poluição do meio ambiente (com redação dada pela Lei $n^{\circ}$ 8.943, de 29/09/94).

SÃO PAULO (Estado). Decreto $n^{0} 10.755$ de 22 de novembro de 1977. Dispõe sobre o enquadramento dos corpos de água receptores na classificação prevista no Decreto $n^{0} 8.468$ de $08 / 09 / 76$ e dá providências correlatas. 
SCHWARTZ, S.I.; PRATT, W.B. Hazardous waste from small quantity generators: strategies and solutions for business and government. Covelo, California: Island Press, 1990.

TOMI, G.F.C. de; FIGUEIREDO FILHO, P.M. de; FERRARI, K.R.; SENHORINHO, N.; CARANASSIOS, A. CARVALHO, S.G. de; BORETTI, E. de A.; MOTTA, J.F.M.; CABRAL Jr., M.; ROMANO NETO, R.; SOUZA, V.C. de. Relatório do Grupo de Mineração e Matérias-Primas. In: PASCHOAL, J.O.A. (coord.) - Projeto Plataforma para Indústria Brasileira de Revestimento Cerâmico - relatório final [São Paulo, SP]: Centro Cerâmico do Brasil, 1999.

TOMMASI, L.R. Estudo de impacto ambiental. São Paulo, SP: CETESB, Terragraph Artes e Informática, 1994. p. 219 - 327.

TOZZINI; FREIRE; TEIXEIRA E SILVA Panorama da proteção ambiental no Brasil. In: I GUIA DE TECNOLOGIAS AMBIENTAIS BRASIL. Alemanha, $1999-2000$, p. $54-58$.

WATHEN, T. Um guia para o comércio e meio ambiente. In: Comércio e meio ambiente: Direito, economia e Política - São Paulo, SP: Secretaria de Estado do Meio Ambiente, 1996, p. 21 - 30. 


\section{ÍNDICE}

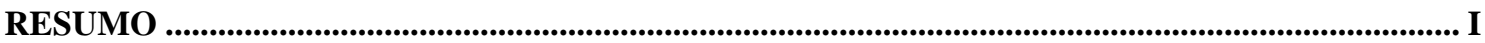

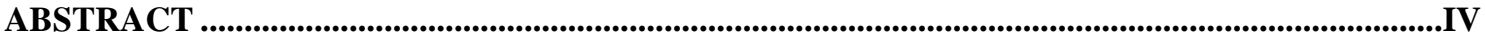

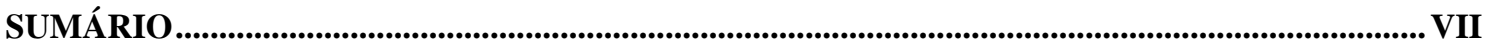

ÍNDICE DE TABELAS....................................................................................................... VIII

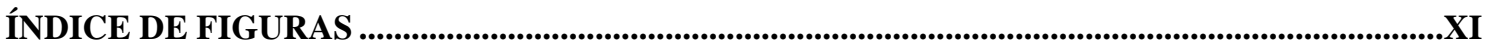

GLOSSÁRIO _...........................................................................................................................................................XI

CAPÍTULO I - INTRODUÇÃO ...........................................................................................................1

I.1. DESENVOLVIMENTO ECONÔMICO EM HARMONIA COM MEIO AMBIENTE, UMA RESPONSABILIDADE GLOBAL ...................................................................

I.2. O SETOR DE REVESTIMENTO CERÂMICO E O MEIO AMBIENTE ....................................10

I.3. AVALIAÇÃO DOS IMPACTOS AMBIENTAIS NEGATIVOS .....................................................18

I.4. OBJETIVOS ..........................................................................................................................................22

CAPÍTULO II - A INDÚSTRIA DE PLACAS DE REVESTIMENTOS CERÂMICOS.....................24

II.1. PANORAMA DA INDÚSTRIA DE PLACAS DE REVESTIMENTOS CERÂMICOS NO BRASIL .................................................................................................................................24

II.2. O PROCESSO DE FABRICAÇÃO DE PLACAS DE REVESTIMENTOS CERÂMICOS................................................................................................................................26

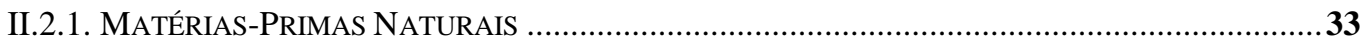

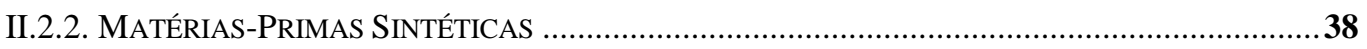

CAPÍTULO III - METODOLOGIA ……………………........................................................................................ 41

III.1. PROGNÓSTICO DOS ASPECTOS AMBIENTAIS ....................................................................41

III.1.1. Desenvolvimento da Metodologia de Avaliação de Impactos

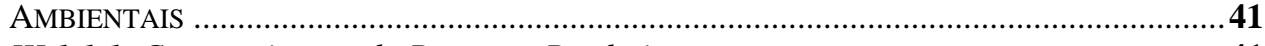

III.1.1.1. Caracterização do Processo Produtivo........................................................... 41

III.1.1.2. Identificação dos Aspectos Ambientais ................................................................42

III.1.2. DeSENVOlVIMENTO DA MatRiZ DE AVALIAÇão DE IMPACTO AMBIENTAL ........................50

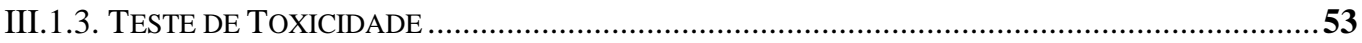

III.2. DIAGNÓSTICO DOS ASPECTOS AMBIENTAIS ...............................................................57

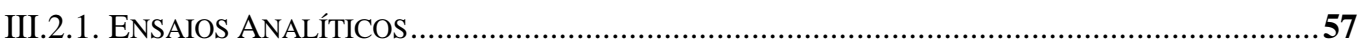

III.2.1.1. Mapeamento do Processo de Produção ................................................................57

III.2.1.2. Coleta e Preservação das Amostras..................................................................59 
III.2.1.3. Técnicas Analíticas..... 61

CAPÍTULO IV - RESULTADOS E DISCUSSÃO 66

IV.1. PROGNÓSTICO DOS ASPECTOS AMBIENTAIS . 66

IV.2. DIAGNÓSTICO DOS ASPECTOS AMBIENTAIS .73

IV.2.1. CARACTERIZAÇÃO DAS MATÉRIAS-PRIMAS NATURAIS .................................................73

IV.2.2. CARACTERIZAÇÃO DAS MATÉRIAS-PRIMAS SINTÉTICAS, DOS RESÍDUOS SÓlIDOS E DOS EFLUENTES LÍQUIDOS

IV.2.3. Discussão SOBRE A EFICIÊNCIA DA METOdOlogia DAS MATRIZES EM RELAÇÃO AOS DAdOS ANALÍTICOS ....

IV.2.4. Discussão SOBRE OS RESUltados DOS TESTES DE TOXICIDADE E ANÁLISES QUÍMICAS NOS EFLUENTES LÍQUIDOS

IV.2.5. SUGESTÃO PARA O DESENVOLVIMENTO DE TRABALHOS FUTUROS..............................118

IV.2.6. DISCUSSÃO DOS ASPECTOS OCUPACIONAIS ....................................................121

CAPÍTULO V - ADEQUAÇÃ AMBIENTAL ...............................................................................130

V.1. SUgestões PARA ADEQUAÇÃo AMBIENTAL PARA INDÚSTRIA DE REVESTIMENTO CERÂMICO

CAPÍTULO VI - CONCLUSÕES 134

APÊNDICE 1 - PLANILHAS DAS NORMAS DA ABNT PERTINENTES AOS ASPECTOS AMBIENTAIS DAS ETAPAS DO PROCESSO DE PRODUÇÃO VIA ÚMIDA DAS INDÚSTRIAS DE PLACAS DE REVESTIMENTOS CERÂMICOS

APÊNDICE 2 - EXEMPLO DE REGISTRO DE DADOS DA ÁGUA DE DILUIÇÃO PARA OS TESTES DE TOXICIDADE AGUDA REALIZADOS NOS EFLUENTES LÍQUIDOS DESTE ESTUDO. 